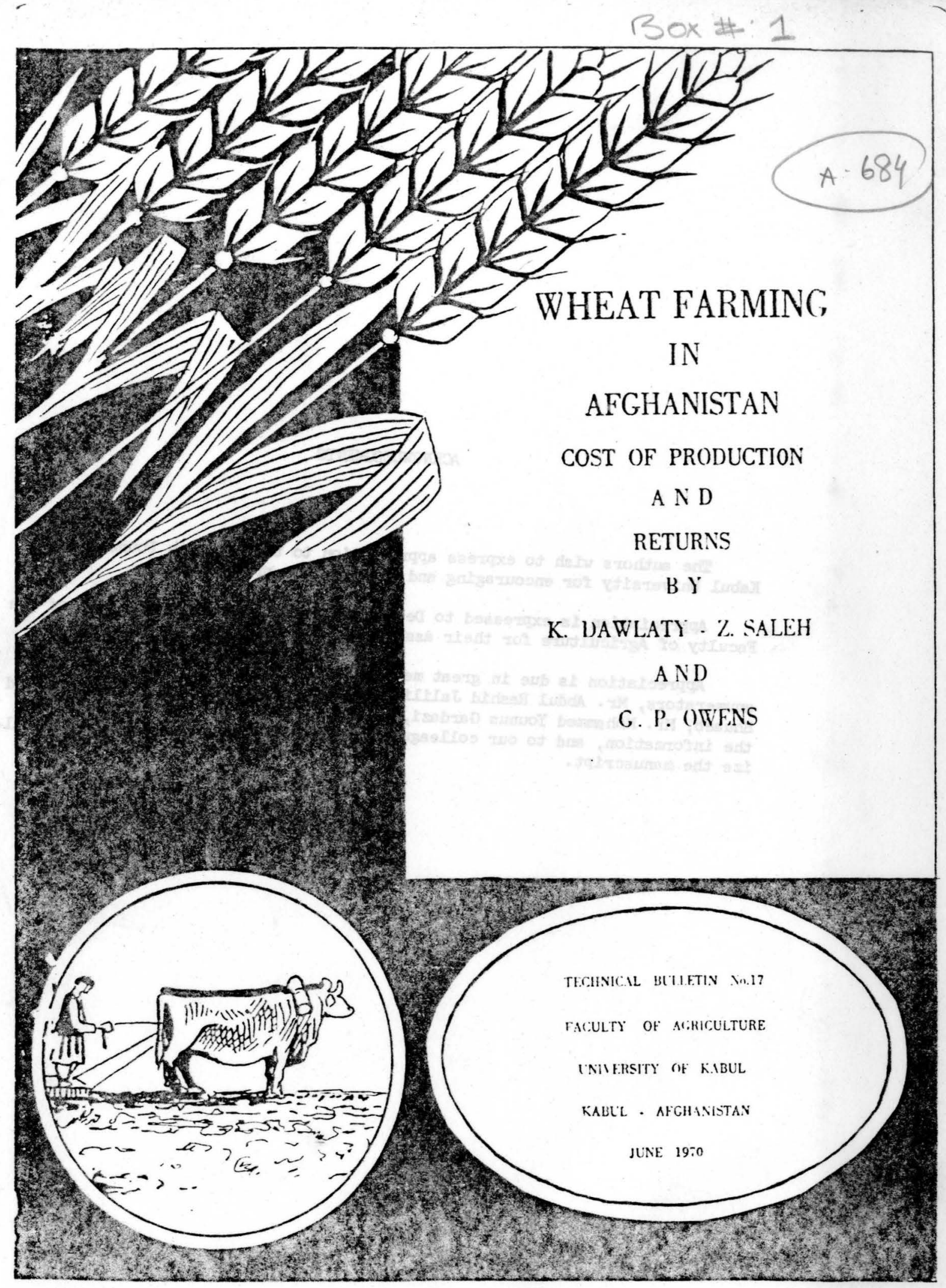


The authors wish to exprass appreciation to the Research Foundation at Kabul University for encouraging and funding this project.

Appreciation is expressed to Dean Alekozai and Azting Dean Nawabi of the Faculty of Agriculture for their assistance and encouragement.

Appreciation is due in great measure to those who did the work -- the enumerators, Mr. Abdul Rashid Jalili, Mr. Mohammed Hakim Malyar, Mr. Mohammed Shuaeb, Mr. Mohammed Younus Gardazi, Mr. Mirdad, to the farmers who provided the infornation, and to our colleagues who helped tabulate the data and finalize the manuscript. 
WHEA T FARMING IN A FGHANISTAN-COST OF PRODUCTION AND RETURRS

\author{
by \\ Khairullah Dawlaty \\ Assistant Professor of Agricultural Economics \\ Zarghuna Saleh \\ General Exonomics Assistant \\ Gerald P. Owens \\ Agricultural Extension Economist \\ The University of Wyoming Tean
}

Technical Bulletin No. 17

FACUITIY OF AGRICUITURE

YABUL UNIVERSITY

Keoul, Afgharistan

July 1970 
TABLE OF CONTENTS

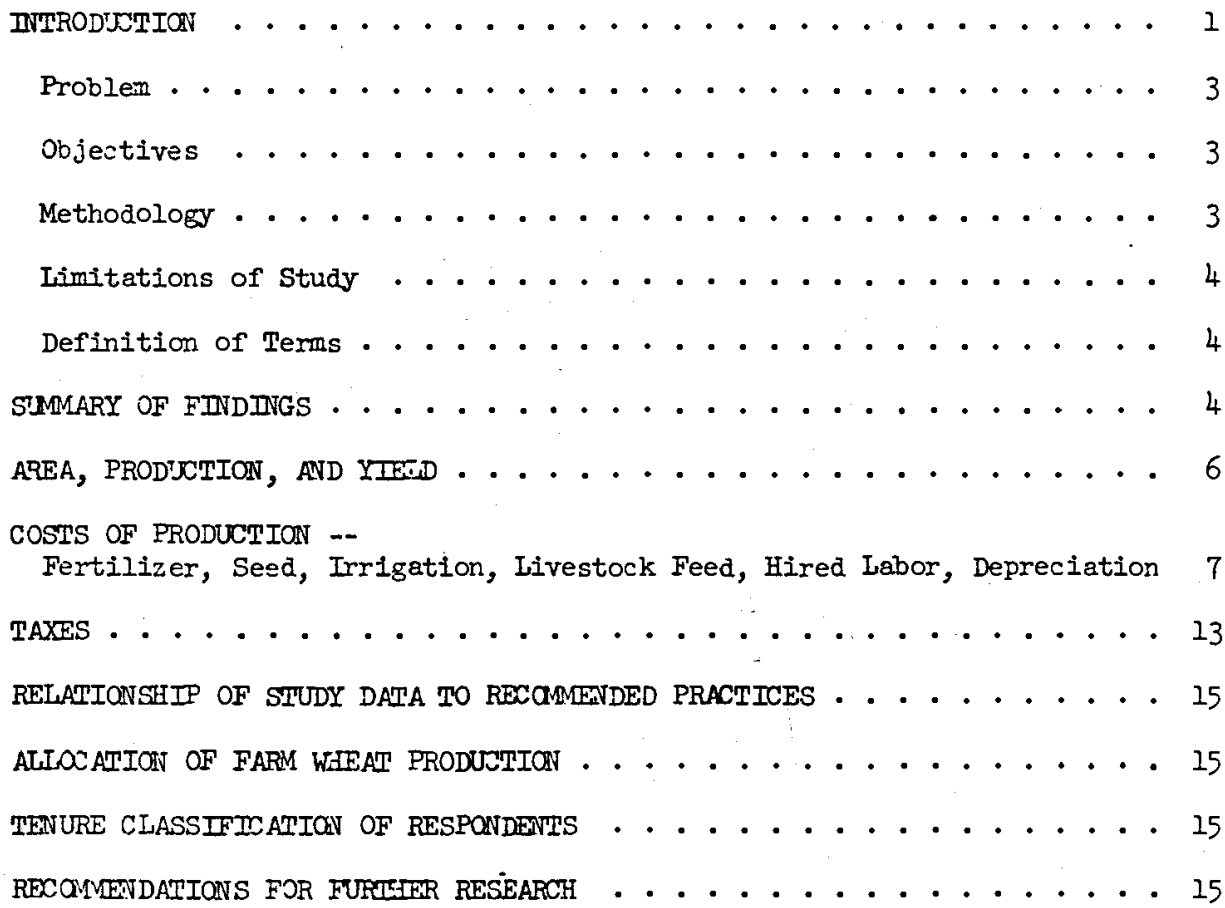


Table 1. AREA, PRODUCTION AND YIEID OF IRRIGAUTED AND DRYLAND WHEATS BY NAPIVE AND IMPROVED VARIEITISS -- AFGHANISTAN -- 1968,

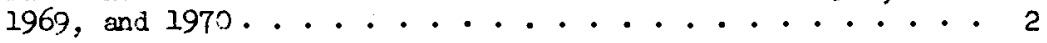

Table 2. AVERAGE COSTS (AFGHANIS) PER JERIB OF PRODUCTYG WHEAP

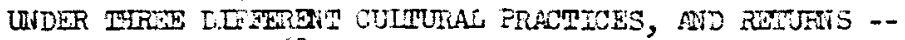

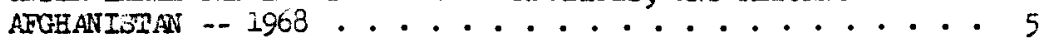

Table 3. AREA, PRODUCTION, AND YIELD: 225 WHEAT FARMS IN AFGHANISTAN $=1958$. . . . . . . . . . . . . . 7

Table 4. COSTS (AFRHANIS) PER JERIB OF PRODUCING IRRIGATED WHEATTRADIMIONAL METEOD AFGILANISTAN - $1968 . . . . . . . . .99$

Table 5. COSTS (AFGHANIS) PER JERTB OF PRODUCING IRRIGATED WHEATIMPROVED METHOD AFGHANISTAN -- 1968......... 10

Table 6. COSPS (AFGEANIS) PER JERIB OF PRODUCING DRYLAND WHEAT AFGHANISTAN

Table 7. LIVESTOCK FEED COSTS (AFGHANIS): 225 FARMS IN AFGHANISTAN $1968 \ldots \ldots 12$

Table 8. LABOR REQUIREMGMTS FOR PRODUCTNG IRRIGATED-TRADTIIONAL WEEAT ON 225 FARMS IN AFGHANISTAN -- 1968 . . . . . . . 12

Table 9. DEPRECIATION OF LTVESTYCK AND EQUIPNENT (AFGHANIS): 225 FAFMS IN AFGHANISTAN $-.1968 . . . . . . . . .14$

Table 10. HYPOTHETICAL COSTS AND RETURNS (AFCHANIS) FOR PRODUCING WHEAT ACCORDING TO RECOM.GENDED PRACTICES -- AFGHANISTAN . • 16

Table 11. AILOCATION OF WHEAT PRODUCTION: 225 FARIS IN AFGHANISTAN

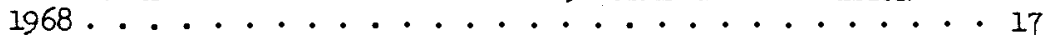

Table 12. TMUTRE CLASSIFIXATION OF:- 225 WIEAT FARAS IN AFGHANISTAN

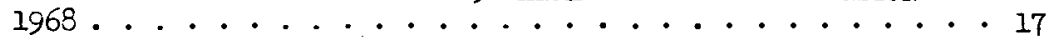




\section{WHEAT FARMING IN AFGHANISTAN -- COST OF PRODUCTION AND RETURNS}

by Khairullah Dawlaty, Zarghuna Saleh and Gerald P. Owens

\section{INTRODUCTION}

Wheat, by far the most important crop in Afghanistan, is grown by traditional methods throughout most of the country. More than half of the wheat acreage in Afghanistan is either irrigated or partially irrigated -- an estimated $7,904,000$ jeribs or $1,530,216$ hectares in 1958. Dryland wheat is produced on mother 7,034,600 jeribs, but the average yield is much lower than for irrigated wheat. Total dryland production nornally accounts for only about 20 or 25 percent of total wheat production.

Afgher wheat is consumed mostly in the form of "nan," a flat loaf made of whole wheat flour leavened by a sourdough culture. It is estimated than nan camprises about half of the Afghan diet.

In past years, Afghanistan was considered a deficit wheat producing area. Favorable weather and high prices during 1967, 1969 and 1959 resulted in increased production, thus reducing the required amount of imports. At present, the Accelerated Wheat Progran of the Ministry of Agriculture and Irrigation is resulting in additional production through the use of improved seeds, chemical fertilizers, and more modern cultural practices. Seed increase efforts have provided many tons of improved seed and farmers' acceptance of the new seeds and fertilizer is encouraging. Self-sufficiency is possible in the very near future if chemical fertilizer is maje available to wheat producers in sufficient quantity. Research trials and demonstrations on farmers' land have shown that it is possible to double or even triple irrigated wheat yields at very little extra cost.

Average yields from improved varieties in the third year of the Accelerated Wheat Program have not been high except on experimental and demonstration plots. Tnis is due to shortages of fertilizer, lack of experience, and other problems tinat plague new programs. Only about $7 \%$ of irrigated wheat acreage will be planted to improved varieties in 1970, according to U.S.A.I.D. estimates. See Table 1 for estimetes and projection of wheat acreage, produstion, and yields in Afghanistan. 
Table 1 .

AREA, PRODUCTION AND YIELD OF IRRIGATED AND DRYLAND WHEATS

BY NATTVE AND IMPROVED VARIETIES -- AFGHANISTAN -- 1958, 1969, and 1970

\begin{tabular}{|c|c|c|c|c|c|c|c|c|c|}
\hline & \multicolumn{3}{|c|}{ IMPROVED } & \multicolumn{3}{|c|}{ TRADITIONAL } & \multicolumn{3}{|c|}{ EOTII } \\
\hline $1968:$ & $\begin{array}{c}\text { Area } \\
\text { (Hec- } \\
\text { tares) }\end{array}$ & $\begin{array}{c}\text { Pro- } \\
\text { duetion } \\
\text { (M Tons) }\end{array}$ & $\begin{array}{l}\text { Yield } \\
\text { (M Tons/ } \\
\text { Hectare) } \\
\end{array}$ & $\begin{array}{c}\text { Area } \\
\text { (Hec- } \\
\text { tares) }\end{array}$ & $\begin{array}{c}\text { Pro- } \\
\text { duction } \\
\text { (M Tons) }\end{array}$ & \begin{tabular}{|c|} 
Yield \\
(M Tons/ \\
Hectare)
\end{tabular} & $\begin{array}{l}\text { Area } \\
\text { (Hec- } \\
\text { tares) }\end{array}$ & $\begin{array}{c}\text { Pro- } \\
\text { duction } \\
\text { (u gons) }\end{array}$ & $\begin{array}{l}\text { Yield } \\
\text { (M Tons/ } \\
\text { Hectare) }\end{array}$ \\
\hline Irrigated & 20,000 & $1,0,000$ & 2.000 & $1,510,216$ & $2,052,604$ & 1.359 & $1,530,216$ & $2,092,60 b_{t}$ & 1.368 \\
\hline Dryliu:al & \multicolumn{3}{|c|}{ insignificaut amounts } & $1,361,917$ & 667,355 & .490 & $1,361,917$ & 657,356 & .492 \\
\hline Tolal & 20,000 & $1,0,000$ & 2.000 & $2,872,133$ & $2,719,960$ & .947 & $2,892,133$ & $2,759,960$ & .954 \\
\hline 19(i): & & 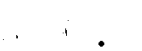 & & & - & & & & \\
\hline Irrigrater & 114,150 & 233,300 & 2.044 & $1,466,547$ & $1,901,287$ & 1.296 & $1,580,697$ & $2,23 !+587$ & 1.350 \\
\hline Dryloud & 7,936 & 5,793 & .730 & $1,278,165$ & 639,360 & .500 & $1,286,101$ & 645,153 & .502 \\
\hline Tutal. & 122,096 & 239,093 & 1.958 & $2,7144,712$ & $2,540,647$ & .926 & $2,865,798$ & $2,779,740$ & .970 \\
\hline 1970: & & & & & & & & & \\
\hline Irrigated & 125,555 & 262,000 & 2.087 & $1,424,435$ & $1,869,000$ & $1 \cdot 311$ & $1,550,000$ & $|2,130,000|$ & 1.374 \\
\hline Dryland & 8,57 & 6,350 & .741 & $1,271,429$ & 637,650 & .502 & $1,280,000$ & 644,000 & .503 \\
\hline Total & 134,136 & 268,350 & 2.001 & $2,695,864$ & $2,505,650$ & .929 & $2,830,000$ & $2,774,000$ & .980 \\
\hline
\end{tabular}

Source: U.S.A.I.D. Agriculture Division 
Problem

A great deal of technical information regarding wheat praduction is available from research efforts of the Ministry of Agriculture and Irrigation. However, little rellable economic information regarding costs of production, returns, and profits is currently avaliable. Econonic information is needed for planning subsequent stages of the Accelerated Wheat Program as well as for individual farm planning. Government policy decisions concerning wheat price supports, imports, and wheat progran emphasis should be based in part on economic information regarding costs and returns for wheat production. This information is also useful for teaching purposes ad future research planning at Kabul Uaiversity.

\section{Oojectives}

The primary purpose of this study was to determine costs of producing wheat by three different methods: 1) Irrigated wheat using traditional methods, 2) irrigated wheat using improved seed and chemical fertilizers, and 3) dryland wheat using traditional methods. (Iittle improved seed is used on dryland acreage).

Another objective was to determine returns for these three different methods of production and to calculate the "profitability" in each case.

\section{Methodology}

Beginning in late 1968, a schedule was drawn up to be administered to wheat farmers by personal interview. This schedule was designed to provide data on all categories of costs of wheat production and to determine yields and wheat prices for the year 1968. This schedule was pretested in the Kabul area and revised according to experiences of the pretest.

A geographical sample was made to include all three types of Afghan wheat farmers. Personal interviews were made with 225 wheat farmers by five enunerators under the direct supervision of the first author. Prior to actual field work, the enumerators were given a two day training course. Information obtained was for the 1968 harvest year (1347) which nad just ended.

The data regarding farm numbers, size, and tenure cannot be projected to yield nationel totals although cost and returns data are considered representative.

The completed interview schedules were checked over in the field and edited immediately after they were returned to Kabul. The data were then used for the analysis of costs and returns for wheat production. 


\section{Limitations of Study}

It is likely that a certain upward bias existed in reporting of the expense data for this study. Whenever possible, the biases were corrected or adjusted on the basis of similar studies of cotton, sugar beets, and farm equipment by the same authors.

The reader is wamed of weakesses in sampling and questionnaire desion which made it difficult to separate or assign costs among the three methods of production. Most of the irrigated-improved wheat in this study was produced in only one area, the Nangarhar region. Furthermore, most of the irrigated-improved wheat was produced on fams which also produced irrigatedtraditional wheat. The year 1347 was the first time a significant amount of irrigated-improved wheat had been produced on private lands in Afghanistan. The cost-returns situations $c$ an be expected to change as farmers gain more experience and as adjustments occur in the supply-demand situations for major inputs.

\section{Definition of Terins}

Irrigated-traditional -- Local wheat varieties grown under full or partial irrigation with little or no chemical fertilizer. These varieties are long-stemed and not very responsive to fertilizer.

Irrigated-improved -- Imported short-strawed (semi-dwarf) wheat which is more disease resistant and more fertilizer responsive than local varieties. These varieties were originally developed in Mexico. They do very well under irrigation with proper fertilization, even with native cultural practices. However, they are little better than local varieties when grown without chemical fertilizers.

Dryland -- Local wheat varieties (usually the same as irrigated-traditional) grown without irrigation.

Jerib -- One jerib equals 0.1936 hectare or 0.4784 acre. kilograms.

Seer -- One seer equals 16 pow (10:al measure), 15.58 pounds, on 7.066

Afghani -- One hundred Afghanis (afs) equals approximately $\$ 1.33$ U. S. (\$1.00 U.S. $=75$ afs).

The Afghar. year 1347 (solar calerdar) runs from March 21, 1968 to March 20, 2969.

\section{SIMAARY OF FIIDIIGS}

Tabie 2 shows zosts and returns for three different methods of wheat production. 
Table 2

AVERAGE COSTS (AFGHANIS) PER JERIB OF PRODUCING WHEAT UNDER THREE DIFFERENT UUITURAL PRACTICES, AND RETURNS -AFGHANISTAN -- 1968

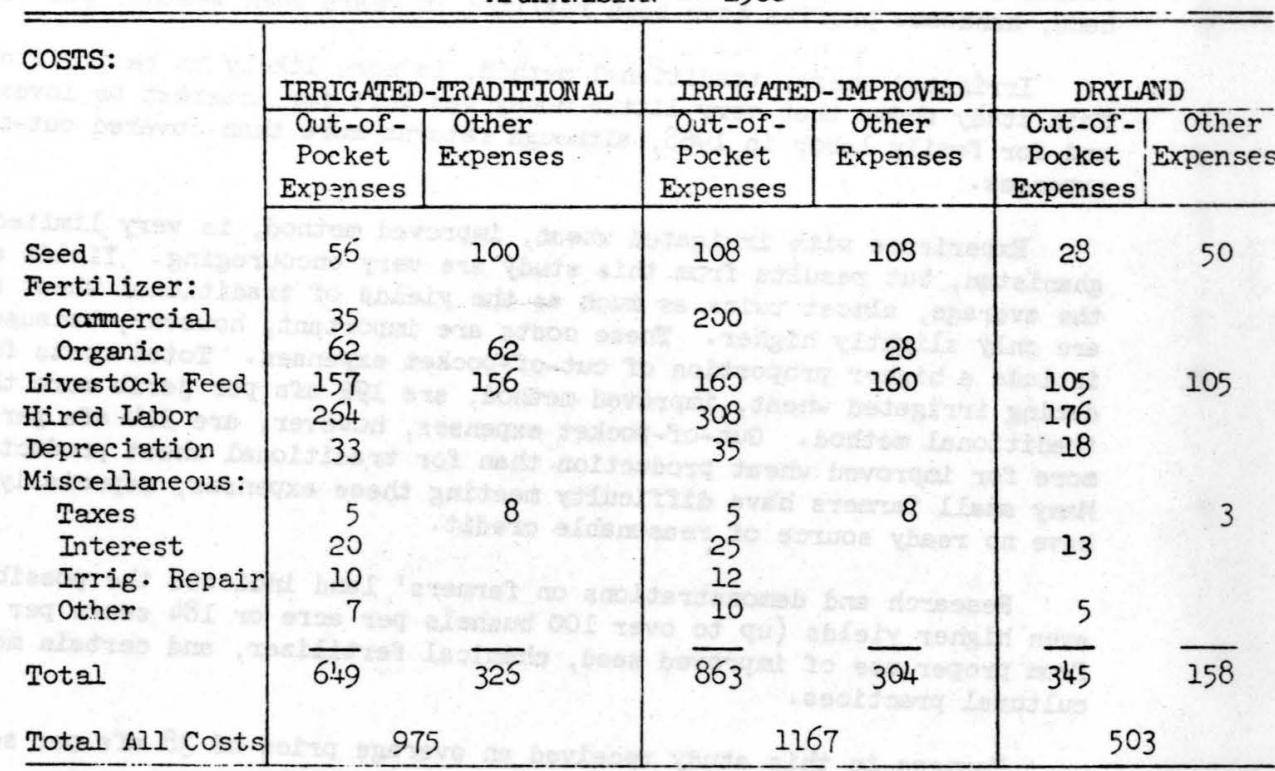

RETURINS:

IRRIG ATED-TRADITIONAL IRRIGATED-IMPROVED

DRYLAND

Wheat
Strawt

Total Receipts

Less out-or-

pocket ex-

penses

Less other

expenses

Returns to fani-

ly labor, memt.

\& interest on

investment......
1049

146

1195

$\frac{6 ! 9}{546}$

326
1957

125

2082

$\frac{863}{1219}$

$-\underline{304}$

$\underline{1.0}$

*Assuming etraw is valued at 3 afs per seer and that 48.7 seers of straw wers obtained per jerib of irrigated-traditional wheat, 18.6 for dryland. Straw production for irrigated-improved wheat was assumed to be about $20 \%$ less tinar. for irrigated-traditional because of the semi-dwarf charateristics. 
Dryland wheat is at best a gamble in Afghanistan. Even though very little out-of-pocket expenses are incurred ( 345 afs per jerib) these may not be recouped because of low yields in years of unfavorable weather. On the other hand, handsome profits have been realized in years when weather was favorable.

Irrigated wheat, traditional method, is more likely to be profitable. This study shows that very little money was left for interest on investrient and for family labor in 1963, although returns more than covered out-of-posket expenses.

Experience with irrigated wheat, improved method, is very limited in Afghanistan, but results from this study are very encouraging. Yields are, on the average, alrost trice as much as the yields of traditional wheat and costs are only slightly higher. These costs are important, however, because they include a higher proportion of out-of-pocket expenses. Total costs for producing irrigated wheat, improved method, are 192 afs per jerib more than for traditional method. Out-of-pocket expenses, however, are 214 afs per jerib more for improved wheat production than for traditional wheat production. Many small farmers have difficulty meeting these expenses, especially if they have no ready source of reasonable credit.

Research and demonstrations on farmers' land indicate the possibility of even higher yields (up to over 100 bushels per asre or 184 seers per jerib) from proper use of improved seed, chemical fertilizer, and certain modern cultural practices.

Farmers in this study received an average price of 38 afs per seer for the wheat they sold.

\section{AREA, PRODUCTION, AND YIELD}

Table 3 shows the number of farms surveyed in each category, total and average acreage, production, and yield. Although only 225 farms were surveyed, many of then produced wheat by more than one method. All the farms wich produced irrigated-improved wheat" also produced irrigated-traditional wheat. Most of the fermers who produced dryland wheat also produced irrigated wheat. tares)

Averaze area in total farmstead for this study was 45.7 jeribs ( 8.8 hes-

Yields reported in this study were sonewhat lower than yields shown in Tacle 1. For exanvie, irrigated-improved yields were estimated at about 55 seers per jerib ( 30 bushels per acre) in 1968 compared to 51.5 seers per jerib reported in this study. In Table 1 , irrigated-traditional wheat is estimated at about 37 seers per jerib compared to 27.6 for this study. 
Table 3.

AREA, PRODIJCTIOI, AND YIELD:

225 WHEAT FARMS IN AFGHANISTAN -- 1968

\begin{tabular}{c|c|c|c|c|c|c}
\hline \hline & $\begin{array}{c}\text { No. of } \\
\text { Farns }\end{array}$ & $\begin{array}{c}\text { Total Area } \\
\text { in Wheat } \\
\text { (jeribs) }\end{array}$ & $\begin{array}{c}\text { Av. Area } \\
\text { Per Farm } \\
\text { (jeribs) }\end{array}$ & $\begin{array}{c}\text { Total } \\
\text { Production } \\
\text { (seers) }\end{array}$ & $\begin{array}{c}\text { Av. Pro- } \\
\text { duction } \\
\text { Per Farm } \\
\text { (seers) }\end{array}$ & $\begin{array}{c}\text { Yield } \\
\text { (seers fer } \\
\text { jerib) }\end{array}$ \\
\cline { 2 - 7 } Irrigated: & 219 & 4151 & 19.0 & 121,814 & 556.0 & 29.3 \\
Traditional & 182 & 3842 & 21.1 & 105,899 & 581.9 & 27.6 \\
Improved & 37 & 309 & 8.4 & 15,915 & 430.1 & 51.5 \\
Dryland & 55 & 2730 & 49.6 & 26,188 & 476.1 & 9.6 \\
All Farns & 225 & 6381 & 30.6 & 148,002 & 657.8 & 21.5 \\
\hline
\end{tabular}

COSTS OF PRODUCTION

At the present stage of development of Afghanistan's agriculture, the most useful categorization of costs is probably 1) "out-of-pocket expenses" -. those for which the farmer inust produce either the cash or credit on a yearly basis and winch are directly related to the production process, 2) indirect expenses winch require a cash outlay at more indefinite times and which are also applicable to other farming or household operations, and 3) payment for family labor and management and returns on investment. In the case of irrigated-improved wheat production, it is important to identify the additional costs (above the costs of producing irrigated-traditional wheat) which must be incurred. This is in contrast to fixed and variable costs.

Fertilizer

Very little, if any, fertilizer is used on dryland wheat. Usually the wheat is planted under conditions which might be described as minimum--minimum cost, minimum tillage, minimum care. The land (often public or normally unused land) is plowed, planted and left alone (except sometimes for a guard) until harvest. This sometimes turns out to be a "little ventured; nothing gained" situation. Good dryland wheat crops are considered windfall gains.

Irrigated-traititional wheat land is usually fertilized with a nixture of bamyard manure, soil and other organic materials at fairly high rates. This study shows an average of 30.7 "donkey loads" (5-7 seers per load) or almost $1 \frac{1}{2}$ tons per jerib. This figure was questioned by the authors, but further investigation provided no basis for lowering the figure. Sane of the sources of this material are bamyard sweepings, irrigation ditch residue and old nud walls. No blanket statement regarding the value of these applications can be made because of lack of knowledge about their nutritive values, particularly 
available nitrogen and phosphorous. Costs per jerib were 124 afs for organic fertilizer and 35 afs for commercial fertilizers totaling 159 afs as shown in Table 4. (See also Tables 5 and 6 ).

Sume farmers also applied cammercial fertilizer to irrigated-traditional wheat. It is not known whether this was nitrogen, phosphorous or both. The averge rate for ali irrigated-traditional farms was about 15 los. per jerib at a cost of about 35 af's.

In this study, fertilizer costs per jerib for irrigated-traditional wheat were only 69 afs lower than for irrigated-improved wheat. However, a higher proportion of the fertilizer costs for irrigated-improved wheat must be classified as out-of-pocket expenses.

Irrigated-improved fertilizer costs were 228 af's per jerib ( 5 seers per jerib at an average cost of 40 afs per jerib for chemical fertilizer). The additional 28 afs were for organic fertilizer. Presumably the chemical fertilizer was in the form of urea and superphosphate or urea and diammonium phosphate in close proportion to M.A. \& I. recomnendations, but at a somewhat lower rate. Application of "organic" fertilizer to improved wheat is not officially recommended although some farmers do apply it.

Seed for dryland and irrigated-traditional wheats is allotted from wheat used for food and is either saved from last year's crop, or purchased (from neighbors or at the bazaar) at near market prices. Average retail price of wheat in 1968 was about 41 afs per seer in fall and winter. Respondents reported a cost of 39.51 afs per seer. Seedling rate reported in this study was 2 seers per jerib for dryland wheat and 4 seers for irrigated-traditional wheat. Seeding rate was about $4 \frac{1}{2}$ seers for irrigated-improved wheat, but price of seed was higher. Irrigated and drylend wheat is planted by "broadcasting" (sown by hand) in Afghanistan. Because much of the broadcasted wheat seed is too deep or too shallow, the seeding rate could be lowered significantly by the use of grain drills or mechanical planters. Although the Ministry of Agriculture and Irrigation sold improved seed to nany farmers at 40 afs per seer, other farmers paid a premium, of money or through barter, in order to obtain improved seeds from other farmers. In I968, the actual cost was about 50 afs per seer. Seed cost appears to be higher in 1969 because of greater demand. Scme farmers in the eastern provinces bartered $2 \frac{1}{2}$ seers of $l o c$ al wheat for one seer of improved Mexipak wheat in 1969.

Irrigated-traditional and irrigated-improved wheats are irrigated about 4 times per season, depending on climatic conditions and water availability. No direct water costs are assigned in this study. Irrigation costs are included in the labor and canal repair categories.

Feed for livestock consists largely of straw with clover or alfalfa and some grain supplement. The animals graze much of the year and are fed mostly when working. During the winter, they receive a minimal diet. (Tabie 7). In most cases, more cases, more than half of the livestock feed is grown on the farm. 
Table 4.

COSIS (AFGHANIS) PER JERIB OF PRODUCING

IRRIG ATED WHEAT-TRADIIIONAL MEIHOD

AFGHANISTAN -- 1968

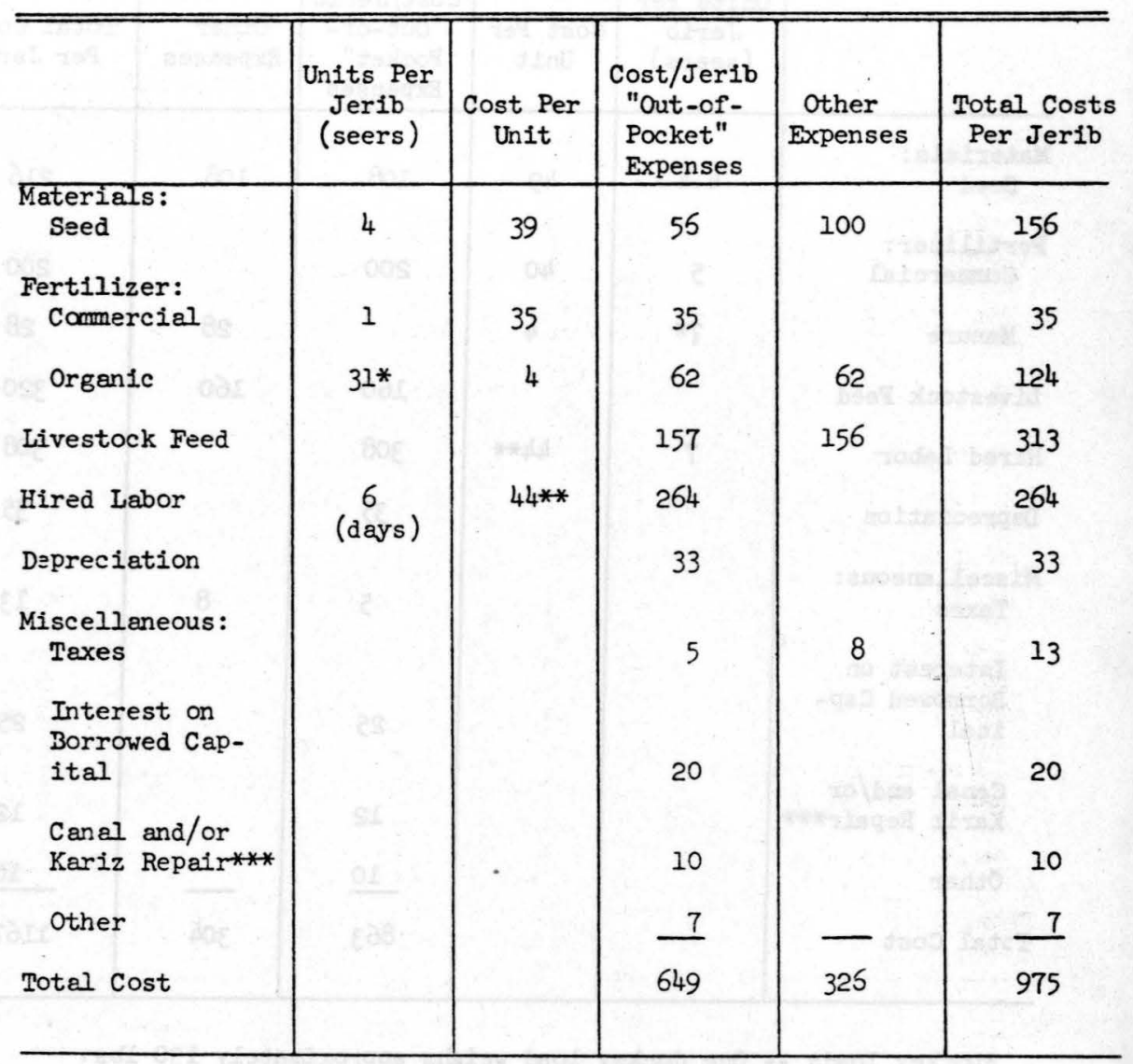

*Donkey loads -- One donkey load equals approximately 130 lbs.

**34 afs plus two meals per day.

***oney contribution only -- does not include equipment usage or labor which is ascounted for in other categories. 
10

Table 5 .

COSTS (AFGHANIS) PER JERIB OF PRODUCING

IRRIG:ATEDD WHEAT-IMPROVIED MEIHOD

AFGIANISTAN -- 1968

\begin{tabular}{|c|c|c|c|c|c|}
\hline & $\begin{array}{c}\text { Units Per } \\
\text { Jerib } \\
\text { (seers) }\end{array}$ & $\begin{array}{l}\text { Cost Per } \\
\text { Unit }\end{array}$ & $\begin{array}{l}\text { Cost/Jerib } \\
\text { "Out-of- } \\
\text { Pocket" } \\
\text { Expenses }\end{array}$ & $\begin{array}{l}\text { Other } \\
\text { Expenses }\end{array}$ & $\begin{array}{l}\text { Total Costs } \\
\text { Per Jerib }\end{array}$ \\
\hline $\begin{array}{l}\text { Materials: } \\
\text { Ssed }\end{array}$ & 4.4 & 49. & 108 & 108 & 216 \\
\hline $\begin{array}{l}\text { Fertilizer: } \\
\text { Cammercial }\end{array}$ & 5 & 40 & 200 & & 200 \\
\hline Manure & $7^{*}$ & 4 & $L^{2}$ & 28 & 28 \\
\hline Livestock Feed & & $x^{2}$ & 160 & 160 & 320 \\
\hline Hired Labor & 7 & $44 * *$ & 308 & & 308 \\
\hline Depreciation & & $354 x_{0}$ & 35 & & 35 \\
\hline $\begin{array}{l}\text { Miscellaneous: } \\
\text { Taxes }\end{array}$ & & & 5 & 8 & 13 \\
\hline $\begin{array}{l}\text { Interest on } \\
\text { Borrowed Cap- } \\
\text { ital }\end{array}$ & & & 25 & & $\sin ^{2}$ \\
\hline $\begin{array}{l}\text { Canal and/or } \\
\text { Kariz Repair*** }\end{array}$ & & & 12 & & 12 \\
\hline Other & & & 10 & - & 10 \\
\hline Total Cost & & & 863 & 304 & 1167 \\
\hline
\end{tabular}

*Dorkey loads -- One donkey load weighs approximately 130 lbs.

**34 afs plus 2 meals per day.

***Money contribution only -- does not include equipment usage or labor which is accounted for in other categories. 
Table 5.

\begin{tabular}{|c|c|c|c|c|c|}
\hline & COSTS (AFC & $\begin{array}{r}\text { HANIS) PE } \\
\text { DRYLAN } \\
\text { AFGHANIST }\end{array}$ & $\begin{array}{l}\text { JERIB OF PI } \\
\text { WHEAT } \\
--1968\end{array}$ & DUCIIG & \\
\hline & $\begin{array}{c}\text { Units Per } \\
\text { Jerib } \\
\text { (seers) }\end{array}$ & $\begin{array}{c}\text { Cost Per } \\
\text { Uait }\end{array}$ & $\begin{array}{l}\text { Cost/Jerib } \\
\text { "Out-of- } \\
\text { Pocket" } \\
\text { Expenses }\end{array}$ & $\begin{array}{l}\text { Other } \\
\text { Expenses }\end{array}$ & $\begin{array}{l}\text { Total Costs } \\
\text { Per Jerib }\end{array}$ \\
\hline $\begin{array}{l}\text { Materials: } \\
\text { Seed }\end{array}$ & 2 & 39 & 28 & 50 & 78 \\
\hline Livestock Feed & & & 105 & 105 & 210 \\
\hline Hired Labor & $\begin{array}{c}4 \\
\text { (man days) }\end{array}$ & $44 *$ & 176 & & 176 \\
\hline Depreciation & 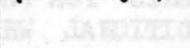 & & 18 & & 18 \\
\hline Miscellaneous: & & & & & \\
\hline Taxes & & & & 3 & 3 \\
\hline $\begin{array}{l}\text { Interest on } \\
\text { Borrowed Cap- } \\
\text { ital }\end{array}$ & zodiatis & tentat & 13 & $b=$ & 13 \\
\hline Other & & & & - & 5 \\
\hline Total Cost & & & 345 & 158 & 503 \\
\hline & & & & & $\frac{11}{2}$ \\
\hline
\end{tabular}

*34 afs plus 2 meals per day. 
Table 7 .

LIVESTOCK FEED COSTS (AFCHANIS):

225 FARMS IN AFGHANISTAN -- 1968

\begin{tabular}{|c|c|c|c|c|c|}
\hline & \multicolumn{2}{|c|}{$\begin{array}{l}\text { Av. Feed Cost } \\
\text { Per Head }\end{array}$} & $\begin{array}{l}\text { Av. No. } \\
\text { Animals } \\
\text { Per Farm }\end{array}$ & $\begin{array}{l}\text { Av. Feed Cost } \\
\text { Per Year } \\
\text { Per Farm }\end{array}$ & $\begin{array}{c}\text { Av. Feed Cost } \\
\text { Per Year } \\
\text { Per Jerib }\end{array}$ \\
\hline & Year & Day & & & \\
\hline $\begin{array}{l}\text { Oxen } \\
\text { Horse } \\
\text { Canel } \\
\text { Donkey }\end{array}$ & $\begin{array}{l}6387 \\
3394 \\
3832 \\
2226 \\
\end{array}$ & $\begin{array}{r}17.5 \\
9.3 \\
10.5 \\
6.1 \\
\end{array}$ & $\begin{array}{r}2.2 \\
.3 \\
.1 \\
1.5\end{array}$ & $\begin{array}{r}13,733 \\
1,154 \\
460 \\
3,273 \\
\end{array}$ & $\begin{array}{r}231 \\
19 \\
8 \\
55 \\
\end{array}$ \\
\hline Total & 15,839 & 43.4 & & 18,620 & 313 \\
\hline
\end{tabular}

Table 8.

LABOR REQUIREMENTS FOR PRODUCING

IRRIGATED-TRADITIONAL WHEAT ON

225 FARMS IN AFGHANISTAN -- 1968

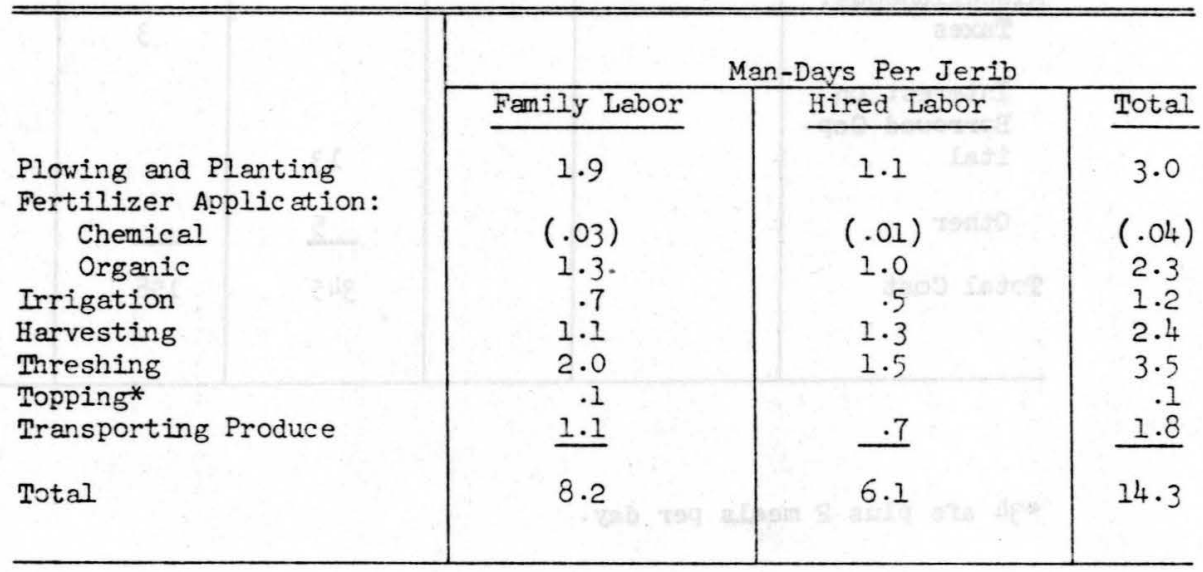

*Wheat is frequently "topped" (leafy parts cut) ir the early stages of plant growth to provide feed for livestock. 
The harvesting and threshing operation(s) require more labor than any other. There are very few combines or threshing machines in Afghanistan and most, if not all of these, are on institutional farms.

Wheat is cut with a hand sickle and brought to a threshing floor in bundles. Oxen are driven over the wheat to separate grain from the straw and chaff. Later, the grain is winnowed, sifted and hand-cleaned in a wicker scoop by a shuffling action.

Plowing and planting is the next most labor-consuming operation. This usually takes place in autumn. Land is stirred (not turmed) one or more times by a stick plow pulled by a yoke of oxen. Clods are sometimes broken up with a locally made harrow. Seeds are sown by hand and covered by pulling a "mallah" or wooden drag over the sown land. There are only about 400 privately owned traators in Afghanistan.

Manure application is the third most labor consuming operation. This involves loading donkeys, or sometimes carts, at the barnyard or from some other source, driving them to the wheat field, unloading, and spreading the fertilizer by shovel. Table 8 shows labor requirements for growing irrigated-traditional wheat. In this case, an insignificant amount of labor is used on chemical fertilizer. For irrigated-improved wheat, the total amount of labor for fertilizing would be less because of less bulk to handle, but total labor requirements are higher because farmers take better care of the crop and have more wheat to harvest and thresh.

Improved wheat varieties have shorter straw, and grain is easier to separate from the straw than the local varieties. Hence, labor costs per seer are less than for traditional varieties. However, since the yield for improved varieties is almost double that of traditional varieties, slightly more total labor is required.

Note that family labor accounts for more than half of total labor. Hired labor is proportionately lower on smaller farms. The bulk of hired labor is used for harvesting and threshing operations and is usually paid in kind.

Table 9 is a straight-line schedule for depreciable livestock and equipment. Average costs, salvage values, and workable life are shown with calculations of yearly depreciation and depreciation costs per jerib. The most costly and numerous work arimal is the ox and next is the donkey. Oxen, according to this study, are slightly more expensive than camels, and also more costly to feed. The oxen are also more useful; indispensable on most farms.

\section{TAXES}

There is a moderate tex on land in Afghanistan which is usually paid by the landowner. Since most of the farmers in this study were tenants, the bulk of taxes are classified as other expenses. 
Table 9.

DEPRECIATION* OF IIVESTOCK AND BQUTRMTNT (AFGHANTS):

225 FARMS IN AFCHANISTAN -- 1968

\begin{tabular}{|c|c|c|c|c|c|c|c|}
\hline$q$ & $\begin{array}{l}\text { Av. Cost } \\
\text { Per Head }\end{array}$ & $\begin{array}{c}\text { Av. Salvage } \\
\text { Value }\end{array}$ & $\begin{array}{l}\text { Work } \\
\text { Iife } \\
\text { (Years) }\end{array}$ & $\begin{array}{l}\text { Depreci- } \\
\text { ation/ } \\
\text { Head/Year }\end{array}$ & $\begin{array}{l}\text { Av. No. } \\
\text { Per Farm }\end{array}$ & \multicolumn{2}{|c|}{$\begin{array}{l}\text { Av. Depr. } \\
\text { Per Year } \\
\text { Per Jerib }\end{array}$} \\
\hline 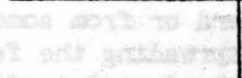 & 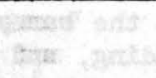 & 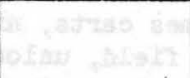 & tropese & antexingob & & chow & Total \\
\hline Oxen & 4910 & 1751 & 9 & 351 & 2.2 & 12.7 & \\
\hline Horse & 3162 & 357 & 12 & 234 & $\cdot 3$ & 1.3 & \\
\hline Camel & 4611 & 1278 & 15 & 222 & .1 & .5 & \\
\hline Donkey & 1097 & 0 & 3 & 137 & 1.5 & 3.4 & 17.9 \\
\hline Plow & 150 & 6 & 2 & 72 & $\cdot 3$ & 2.5 & \\
\hline Other Bquip.** & 5000 & 0 & & 6. $320=0$ & & 12.9 & 15.4 \\
\hline Total & 18,930 & 3, 392 & & & & & $33 \cdot 3$ \\
\hline 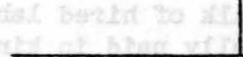 & te stal & & & & & & \\
\hline
\end{tabular}

*Straight-line method.

* Donkey saddles, carts, shovels, sickles, mallah (harrow), grain bags, strew nets, chains, ropes, etc. (estimated). 
RELATIOAISHIP OF STUDY DATA TO RECOMMENDED PRACTICES

It is interesting to speculate on the cost and return situation if farmers had followed the advice of the Ministry of Agriculture and Irrigation. Table 10 shows costs, including recomended anounts of fertilizer, and returns at a slightly higher yield. Preliminary evidence from research indicates that higher rates of fertilization would be even more profitable,

\section{ALLOCATION OF FARM WHEAT PRODUCTION}

Half of all wheat produced on farms in this study was used for home consumption. If the assumption that farms in this study are above average in size and efficiency is correct, we can safely assume that more than half of Afghanistan's wheat production is for home consumption. Table 11 shows percentages of wheat used for various purposes.

Only nineteen percent of production was sold from farms in this study and actual sales may be even lower for the country as a whole. However, some of the wheat used as payment in kind and a significant amount of wheat used for loan repayment eventually goes through marketing channels, which may handle as much as 25 or 30 percent of the total wheat crop in Afghanistan. Some seed goes through marketing channels and same wastage occurs during marketing.

\section{TENURE CLASSIFICATION OF RESPONDENTS}

Table 12 shows tenure classification for the 225 farms surveyed. Sharecroppers are by far the most numerous group, followed by full-owners. Details of the landlord-tenant relationship were not investigated in this study, but they are known to be quite diverse from results of other studies. Share arrangements depend primarily on the relative contributions of labor, seed, equipment, water, size of farm, and animal power by landlord and tenent. Land productivity, kinship, cropping patterns and other considerations may also affect the share arrangements.

In this study, a significant amount of information on tenants' farms was supplied by their landlords. In Afghanistan, it is common for the landlord to be more knowledgeable, especially in the case of tenants whose contribution is very little more than their own labor. Furthermore, many tenants are reluctant to provide information except in the presence of their landlords.

The above tenure information cannot be considered characteristic of Afghanistan as a whole. Tenure patterns for the entire country are not available either through complete census or extensive sampling.

\section{RECOMMENDATIONS FOR FURTHER RESEARCH}

Additional economics studies of costs and returns must be made to cover the whole country. In the future, these should be done in nore detall, and more attention should be paid to allocating general costs to the various enterprises. 
Table 10.

HYPOIHETICAI COSTS AND REITRNS (AFGHANIS) FOR PRODUCING WEEAT ACCORDTIG TO RECCMMTDED PRACTICES -- AFGRANISTAN

\begin{tabular}{|c|c|c|c|c|c|}
\hline & \multirow[b]{2}{*}{$\begin{array}{l}\text { Units Per } \\
\text { Jerib } \\
\text { (seers) }\end{array}$} & \multirow[b]{2}{*}{$\begin{array}{l}\text { Cost Per } \\
\text { Unit }\end{array}$} & \multicolumn{2}{|c|}{ Cost Per Jerib } & \multirow[b]{2}{*}{$\begin{array}{l}\text { Total Cost } \\
\text { Per Jerib }\end{array}$} \\
\hline & & & $\begin{array}{l}\text { "Out-of- } \\
\text { Pocket" } \\
\text { Expenses }\end{array}$ & $\begin{array}{l}\text { Other } \\
\text { Expense }\end{array}$ & \\
\hline $\begin{array}{l}\text { Materials: } \\
\text { Ssed }\end{array}$ & 4.5 & 49 & 110 & 110 & 220 \\
\hline $\begin{array}{l}\text { Chemical Fertilizer } \\
\text { Iivestock Feed }\end{array}$ & $\begin{array}{l}4.0 \text { urea } \\
6 \text { super p }\end{array}$ & $\begin{array}{l}35 \\
15\end{array}$ & $\begin{array}{r}140 \\
90 \\
160\end{array}$ & 160 & $\begin{array}{r}140 \\
90 \\
320\end{array}$ \\
\hline Hired Labor & 7 (days) & 44 & 309 & & 308 \\
\hline Depreciation & 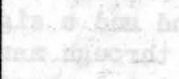 & & 35 & & 35 \\
\hline $\begin{array}{l}\text { Miscellaneous: } \\
\text { Texes }\end{array}$ & 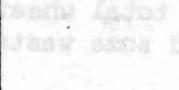 & & 5 & 8 & 13 \\
\hline $\begin{array}{l}\text { Interest on } \\
\text { Borrowed Capital }\end{array}$ & & & 25 & & 25 \\
\hline $\begin{array}{l}\text { Canal and/or Kariz } \\
\text { Repair }\end{array}$ & 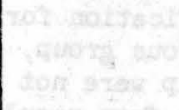 & & 12 & & 12 \\
\hline other & 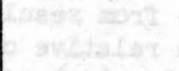 & & 10 & - & 10 \\
\hline Total Cost & 9. fistiterat & & 895 & 278 & 1173 \\
\hline
\end{tabular}

REMURTS:

\begin{tabular}{lr} 
Wheat $\quad 60$ seers @ 38 afs/seer* & 2280 \\
Straw & 125 \\
& \\
Total Receipts & 2405 \\
Less out-of-pocket expenses & $\underline{895}$ \\
& 1510 \\
Less other expenses & 278 \\
\hline
\end{tabular}

Returns to fanily labor, mgnt., and interest on investment 1232

* Results fram demonstrations conducted on farmers'land indicate that 60 seers per jerib is a reasonable yield with improved seed, recommended fertilizer application and traditional cultural practices. 
Table 11.

AIIOCATION OF WHEAT PRODUCTION:

225 FARUS IN AFGHANISTAN -- 1968

\begin{tabular}{lc} 
& $\begin{array}{c}\text { Percent of Total } \\
\text { Production }\end{array}$ \\
\cline { 2 - 2 } Home Consumption & 50 \\
Sales & 19 \\
Seed (for coming year) & 12 \\
Payment in Kind & 9 \\
Waste & 8 \\
Loan Repayment & 2
\end{tabular}

Table 12.

TZIURE CLASSIFICATION OF:

225 WHEAT FAR'S IN AFGHANISTAT -- 1968

Full-owner Operators

Nunber of

Farms Percent

Part-owner Operators

61 27

Crop-share Terients

$39 \quad 17$

Renters

$105 \quad 47$

17 ह

Combination Renter-Sharecropper

$3 \quad 1$

$225 \quad 100$

Note: Iandlords (owner-non-operators) supplied information for approximately 54 percent of the tenar.ts and renters. 
An even greater need is a series of studies to determine optimum fertilizer levels in various geographical areas. The research should be designed and carried out with sufficient precision to permit marginal analysis at various altemative costs for seed and fertilizer.

There is, or soon will be, a strong need for research in wheat marketing and processing. Atcmism and lack of marketing information have already been observed in both the markets for agricultural inputs and outputs. Research will be necessary to guide market development, which must keep pace with agricultural technology if the overall economy is to maintain a balanced growth. 


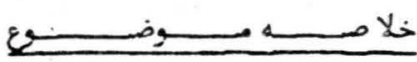

اين رســاله محتــوى سطالب و معلومات مغصل اقتصاد ى د ر قسمت توليد كند م

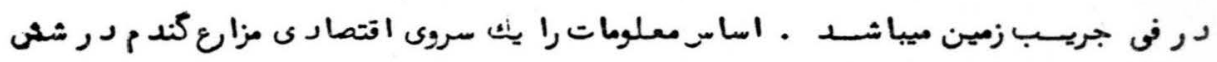

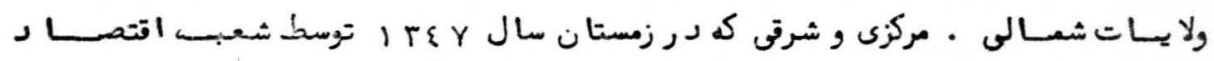

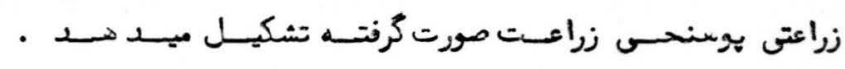

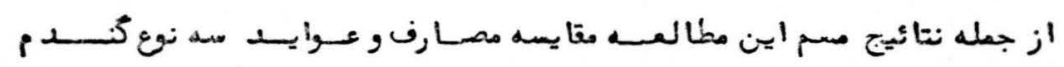

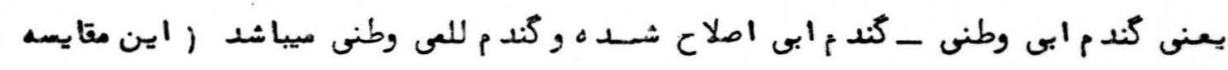

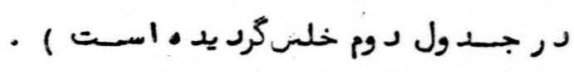

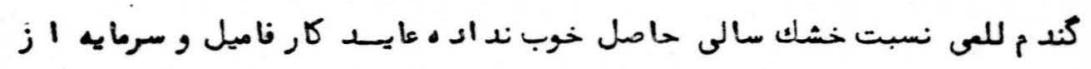

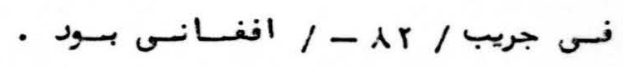

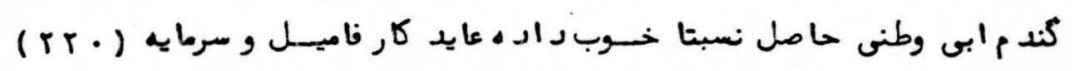

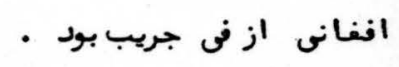

كند م ابى الهلاح شد ه ك با كود كياوى كاشته شده بود با وجود اينكه دماقيــن

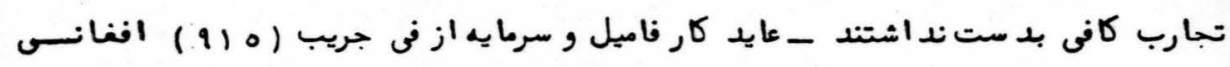

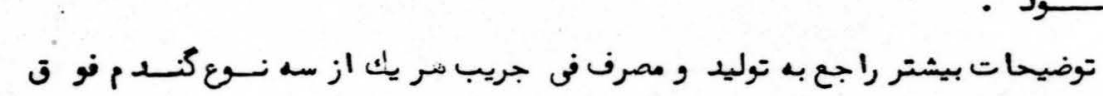

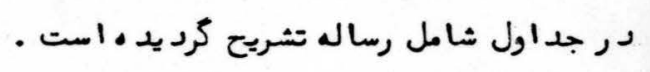

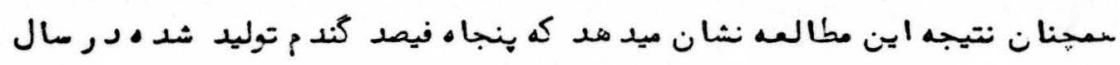

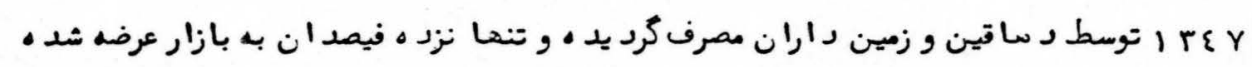

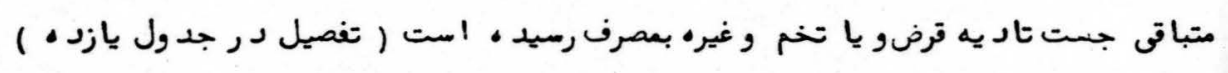

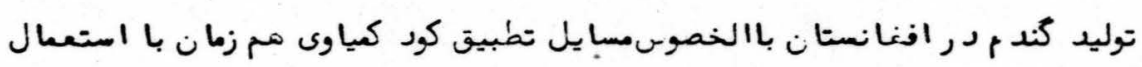

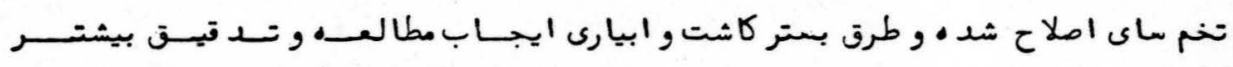

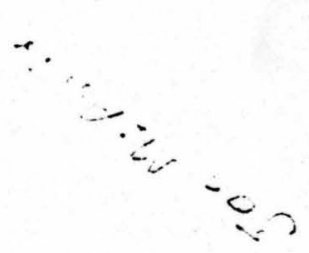


K. Dawlaty, R. K. Harlan

G. P. Owens
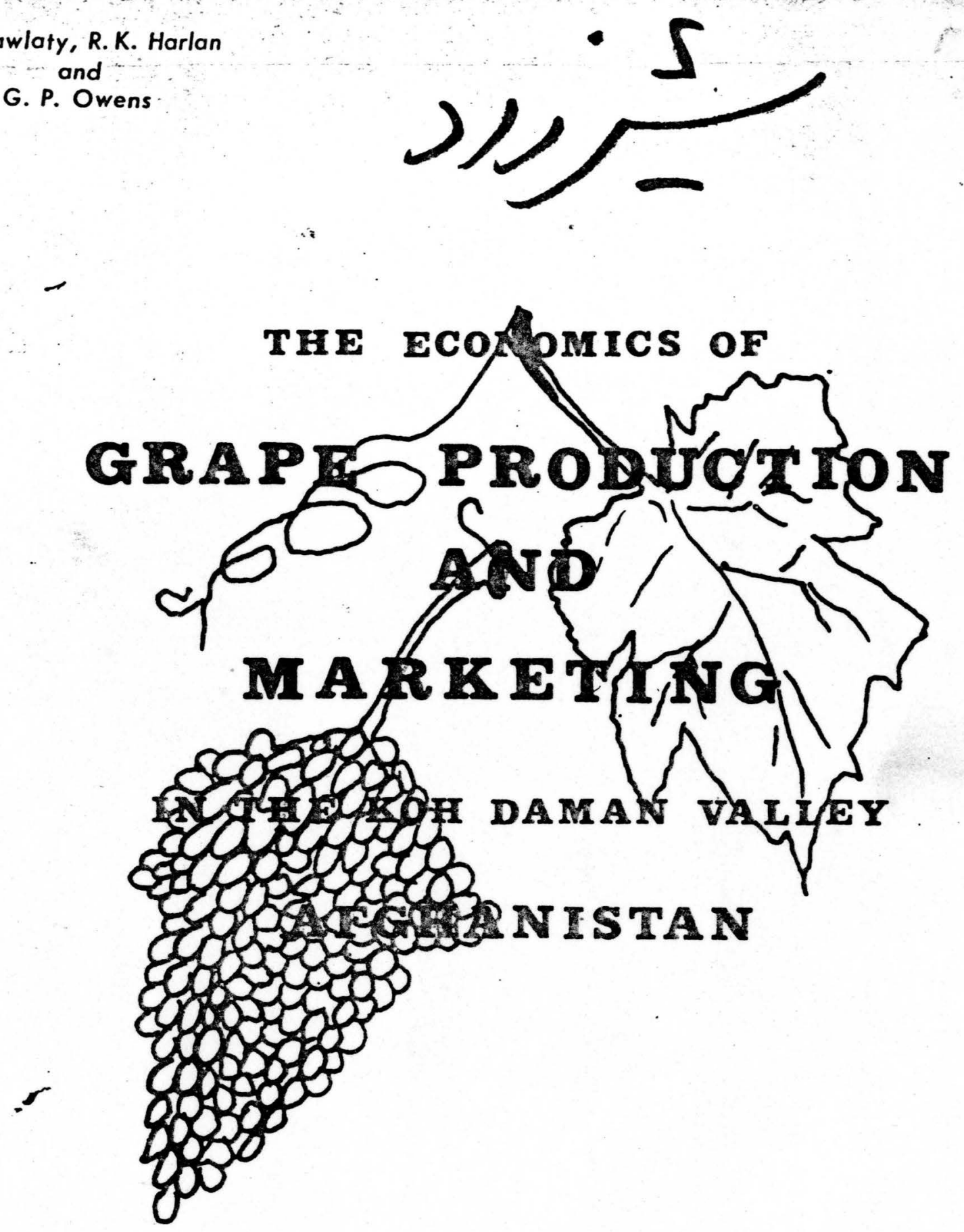

TECHNICAL BULLETIN 7

KABUL UNIVERSITY

FACULY OF AGRICULTURE

Kabul, Afghanistan

November, 1967 


\title{
THE ECONOMICS OF GRAPE
}

\section{PRODUCTION AND MARKETING}

\section{IN THE KOH DAMAN VAUEY,}

OF AFGHANISTAN

\author{
by \\ K. Dowlaty R. K. Harlan \\ and \\ G. P. Owens
}

Kabul University

Faculty of Agriculture

November 1967 


\section{Acknowledgements}

The authors wish to express their gratitude to Dr. Shah M.Alekozai, Dean, Faculty of Agriculture, Kabul University and toDrs. J.W. Oxley and R. E. Pfadt, Chiefs of Party, Wyoming Tea $\mathrm{m}$, for their help and encouragement on this research project.

The cooperation and assistance of the following government officials is gratefully acknowledged:

-Mr. Abdul Aziz, Governor of Parwan

-Mr. Saka, Sub-Governor of Qarabaugh

-lir. Hamed Azizi, Sub-Governar of Sarai Khoja.

-Mr. Abdul Hamid, Director of Agriculture, Parwan

The following faculty and staff members of Kabul University gave generously of their time and skills:

-Mr. A. W. Gulistani

-Dr. M. A. Samimi

-Mr. Abdul Mobin

-Mr. Babrak

-Mr. Mir Abbas Frahmand 


\section{Table of Contents}

Page

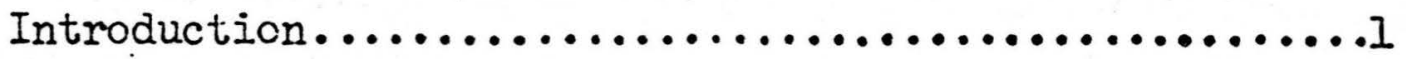

Problem...$\ldots \ldots \ldots \ldots \ldots \ldots \ldots \ldots \ldots \ldots \ldots \ldots \ldots$

Production - Part I............................2

objectives...............................2

Description of Area.........................2

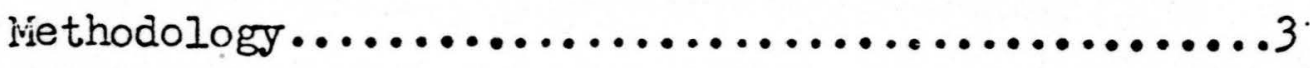

-Family Composition.........................

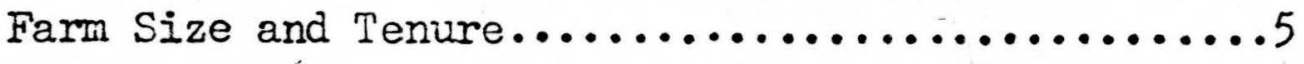

Production Costs and Labor Requirements..........8

Production and Returns........................10

Credit Activities..........................16

Farmers Problems..........................16

Sumary and Recomrendations...................17

Narketing - Part II............................ I

Introduction.......................... Is

Retail Prices in the Koh Daman Valley........... I 
Interviews with Truckers Loading Grapes in the Koh Daman Valley...................18

The Kabul Wholesale Fruit Market...............24 Kabul Retail Fresh Fruit Narket..............25

Export of Grapes........................29

Export of Raisins.......................29

Summary...............................29

Abstract (in Persian).................................. cover 


\title{
OF GRAPE PRODUCTION AND MARKETING \\ IN THE KOH DAMAN VALLEY, AFGHANISTAN
}

\author{
K. Dawlaty R. K. Harlan and G. P. Owens'
}

\section{INTRODUCTION}

Grape production and marketing represent a significant part of Afghanistan's agricultural industry. Raisins and fresh grapes form an important part of the Afghan diet and are major export commodities. Fresh grape exports represent about five percent of the total fresh fruit produced, and raisin exports are approximately ten percent of the total dried fruits.

Data from the Ministry of Commerce show that fresh grape exports doubled in the three-year period 1963, 1964 and 1965. Raisin exports increased about 32 percent from 1961 to 1962 and 47 percent from 1961 to 1963. However, exports declined 27 percent from 1963 to 1964. Since 1964 raisin exports have increased significantly due to more efficient operation of the new raisin processing plant. 2
More liberal trade agreements with Pakistan and India probably account for most of the increase in fresh grape exports; the same can be said for raisin exports in 1962 and 1963. The decrease of raisin exports in 1964 was probably due to the emphasis on fresh grape exports, leaving less available for the processing of raisins.

Expansion of the export market increases the importance of grape production as a money crop, and favorable producer prices tend to motivate adoption of improved production methods to increase output. An increasing volume of grape and raisin exports also adds more foreign exchange to Afghanistan's trea sury. The Problem

Planning a program to assure sustained economical development of Af-

1 K. Dawlaty is Pohanyar of Agricultural Economics at the Faculty of Agriculture, Kabul University.

R. K. Harlan is Professor and hdvisor in Agricultural Economics, University of Hyoming Team at the Faculty of Agriculture, Kabul University. G. P. Owens is Agricultural Economist, University of :yoming Team; Advisor in Agricultural Economics to the Kinistry of Agriculture and USAID Agriculture. 
ghanistan's agriculture requires sound decisions as to which agricultural commodities should be given priority in using scarce resources to maximize economic returns. Agricultural advisors often are concerned with whether it would be more de sirable to exert greater effort and resources toward becoming self-sufficient in all major commodities, or to encourage more specialization in producing certain commodities and rely on foreign trade for other needs.

Input-output and marketing data for agricultural production in Afghanistan are extremely limited but are essential for analyzing the economic aspects of allocating scarce resources to produce those commodities which will maximize returns. Data developed from controlled experiments and collected from surveys of this type provide a base from which commercial farmers can develop their individual operational plans and budgets. Since no previous economic research of the grape industry in Afghanistan has been done, this must be considered a pilot study. In addition to supplying information on production, marketing, and export of grapes and raisins, this study should provide guidelines for future economic research concerned with major commodities.

\section{PRODUCTION}

Part I

\section{Objectives}

The overall objective of Part I of this survey was to determine the costs and returns of producing grapes in the Koh Daman Valley of Afghanistan. The more specific chjectives were:

1. To determine requirements per jerib ${ }^{3}$
a. family labor
b. hired labor

2. To determine quantity and costs of other inputs per jerib

a. amount and cost of fertilizer and pesticides

b. equipment depreciation and other fixed costs

c. miscellaneous supply costs

3. To determine returns per jerib

a. from fresh grapes

b. from raisins

c. value of grapes consumed by family

Description of Area

The most important grape-producing provinces of Afghanistan are Kabul, Parwan (Koh DamanValley) and Kandahar. The provinces of Herat and Logar produce a relatively large volume but almost all of it is consumed locally. Iimited quantities are produced and consumed in the provinces of Ghazni, Baghlan, Kunduz, Badakshan, and Kapisa, and in the Vaygul Valley of Nooristan.

The Koh Daman Valley, where this study vas made, is just north of Kabul. It and areas around it probably make up the largest and most important grape-producing region in Afghanistan. This valley begins approximately 13 kilometers north of Kabul and extends for nearly 60 kilometers. It is accessible from north of the Hindu Kush mountains through the Salang Tunnel. The Koh Daman Valley is surrounded by several ranges of the HinduKush mountains. The Sorkh Koh range north of

3 One jerib $=.4784$ acre or .1936 hectare 
Jabul-i-Saraj forms the northern boundry; the Khwaja Syaran, with height s up to 10,037 feet is on the west; and the Sofi range bounds the eastern side. The Khair Khana Pass through a foothill range provides access to the valley at its southern end about 13 kilometers north of Kabul.

The breadth of the grape-producing area in the Koh Daman Valley extends to about 15 kilometers. Its length is about 50 kilometers, reaching from Qalai Murad Big a few kilometers north of Charikar. Annual precipitation ranges from 320 to $350 \mathrm{~mm}$. Irrigation is essential for grape production, but some dryland wheat farming is practiced in the southwe st area of the valley. The main source of irrigation water is from the Gorband River, the Panj Shirr River, kurezes and springs.

Most farmers of the valley specialize in grape production. About 25 percent of the land is planted to vineyards. Other fruits, wheat, barley and vegetables are also grown. The Koh Daman Valley shows recent signs of expanding

its grape production. New vineyaras are appearing on both sides of the highway which passes through the length of the valley. Newly established vineyards were also observed in all parts of the valley visited in the course of this survey. Improved transportation facilities and expanding markets have undoubtedly supplied the stimulus for this expansion. The area surrounding the two market towns of Sarai Khwaja and Qarabagh account for 75 percent of the valley's total grape production. These two towns are located on the paved highway 53 and 70 kilometers north of Kabul, respectively.

\section{Methodology}

Data for the production portion of this study were collected by personal interview surveys during February and March of 1966. A previous attempt to collect these data was made during the same period in 1965, using an English language questionnaire. When data collected with the English schedule were edited and tabulated, too many inconsistencies were discovered and the data were not used.

The first experience proved a good test of the questionnaire. A revised questionnaire was developed in the Dari language which made it possible for the interviewers, whose native language is Dari, to ask the questions with less distortion of their intended meaning than when questions were translated From written English to oral Dari.

Before interviewing any of the grape oroducers, preliminary courtesies were zarefully observed. The Provincial jovernors and sub-governors were visited to give permission to conduct the survey, On hearing the description of the project, and explanation of its purpose, these persons in responsible positions expressed interest and gave approval without hesitation. This clearance was obtained well enough in advance to enable the governors and sub-governors to notify their village chiefs of when to expect a visit from the survey team This was not the case with the first attempt, and the villagers were sometimes suspicious and would tend to hedge or give unrealistic answers when responding to questions they were asked.

During the first survey most of the interviewing was done at the village mosque where a group of the villagers would collect to be questioned. In this situation, when a farmer would hesitate in his response to a question, two or three others would speak up to supply answers for him. Too often these 
answers probably were not reliable.

The second survey was conducted during a three-week period by three Afghan staff members and two senior students from the Faculty of Agriculture. One hundred grape producers were interviewed in 33 different villages selected at random from the four areas. Figure 1 shows the approximate $10 \mathrm{ca}-$ tions of these villages. Several of the farmers interviewed were contacted while in the villages. Others were contacted individually while pruning vines or shoveling their vineyards (cultivating with shovels).
A careful explanation to the farmers as to the purpose of the study and assurance that the information being sought would never be used to their disadvantage served to minimize suspicions, and to improve the reliability of their responses compared with responses from the first attempt. It is aiso believed that a greater percentage of private contacts with individual farmers produced more reliable data.

The four main areas, the villages within each area where interviews were made, and the number of interviews per village are as follow:
Areas

I. Char-i-Kar:

II. Bagram:

III. Quarabagh:
No. Interviews

$$
\begin{aligned}
& \text { 1. Baba Khail } \\
& \text { 2. Dolana } \\
& \text { 3. Dah-i-Quazie } \\
& \text { 4. Sofi Yan } \\
& \text { 5. Quali-Chi-Sokhta } \\
& \text { 6. Totom Dara } \\
& \text { 7. Dahi Mula Yousufe } \\
& \text { 8. Dahi Hazara } \\
& \text { 9. Toghberdie } \\
& \text { 10. Desht-i-Ofian } \\
& \text { 11. Char-i-Kar City } \\
& \text { 12. Qalai Belan }
\end{aligned}
$$

Total

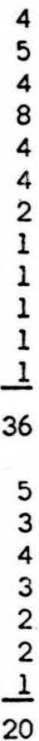

$$
\begin{aligned}
& \text { 1. Khanjar Khail } \\
& \text { 2. Nowdeh } \\
& \text { 3. Qualai Nasro } \\
& \text { 4. Dahi Mullah } \\
& \text { 5. Qualai Beland } \\
& \text { 6. Ghulam Ali } \\
& \text { 7. Shaikha }
\end{aligned}
$$

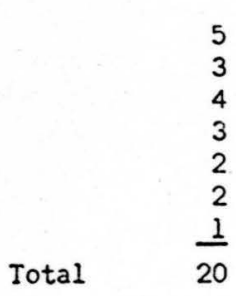

$$
\begin{aligned}
& \text { 1. Subze Sung } \\
& \text { 2. Aller } \\
& \text { 3. Quarabagh Bazaar } \\
& \text { 4. Gul Darah } \\
& \text { 5. Khowaja Hassan } \\
& \text { 6. Jarchie }
\end{aligned}
$$

Total

$\begin{array}{r}4 \\ 5 \\ 4 \\ 2 \\ 3 \\ 1 \\ \hline 19\end{array}$

IV. Sera-i-Khoja:

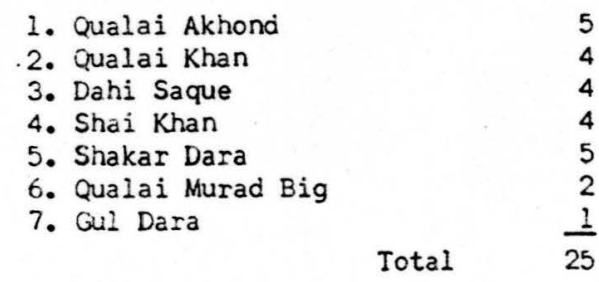


The individual schedules concerning the production part of this study were edited, analyzed, and summarized. Data obtained were not limited to inputoutput information of grape production but included information about $f \mathrm{arm}$ size, tenure, family composition, credit activities, farm power and implements, and farmers' opinions as to their most serious problems.

Family Composition

The farm family ranged in size from two members to 26. Average size of the family is 9.39 members. Table 1 , below, shows composition of the average family as to number of members according to sex and number of members in each of three age groups.

On the average, more than one-half (58 percent) of the family members a re of working age (13-60 years). About 39 percent are too young to work and a little more than 3 percent are too old. An average of five (5) working-age members per family is a relatively adequate family labor force for the average size vineyard except during the peak harvest season.

Farm Size and Tenure

Farm size varied greatly among the 100 producers interviewed. It ranged from .25 jerib to 500 jeribs, and averaged 19 jeribs (vineyard and other cropland). Five of the largest farms account for 56 percent of the total holdings of the 100 farms surveyed. If these five large farms were not included, average size for the remaining 95 farms is 8.9 jeribs (søe Table 2).

The number of jeribs in vineyard ranged from. 25 to 33 for the 100 farms surveyed, with an average size of 3.5 jeribs. Again excluaing the five large farms, the vineyards of the remaining 95 farms averaged three jeribs. Of the entire 100 farms, the five large farms contained 14 percent of total land in vineyards. That portion of total farmland in vineyards for all 100 farms was 18.17 percent. With the five large farms excluded, the portion of total farmland in vineyards was 34.83 percent. Only five percent of the total farmland of the five large farms was in vineyards All of the five large farms are located in the Bagram area where there is a considerable shortage of irrigation water. This and a shortage of labor during peak seasons probably are deterrents to the planting of more land to vineyards in this area.

Almost all of the 100 farmers interviewed owned the land which they operated. Only three farmers "rented in" extra land. They rented an average of 22.6 jeribs each. Total land holdings for the 100 farmers was 1,920 jeribs, of which 1,430 jeribs were in crop production and 347.8 jeribs (18.17 percent) were in vineyards.

Table 1. Family Composition of 100 Farm Families, 100 Farms, Koh Daman Valley, 1966

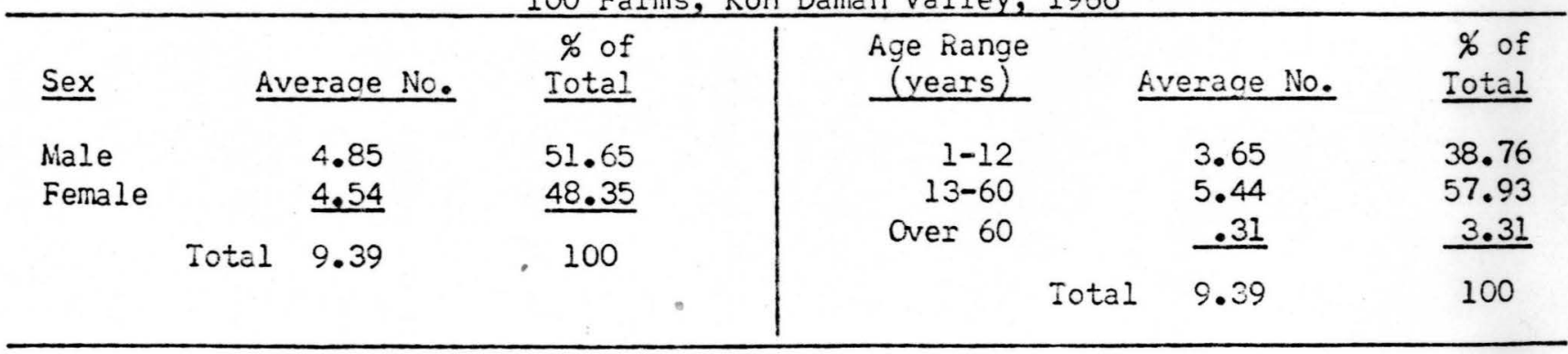




\begin{tabular}{|c|c|c|c|c|c|c|c|}
\hline $\begin{array}{l}\text { Farm } \\
\text { Group } \\
\end{array}$ & $\begin{array}{l}\text { Total } \\
\text { Farm } \\
\text { Land } \\
\text { (Jerios) } \\
\end{array}$ & $\begin{array}{r}\% \text { of } \\
\text { Total } \\
\end{array}$ & $\begin{array}{c}\text { Av. Faym } \\
\text { Size } \\
\text { (Jeribs) } \\
\end{array}$ & $\begin{array}{c}\text { Total } \\
\text { Vineyard } \\
\text { Land } \\
\text { (Jeribs) } \\
\end{array}$ & $\begin{array}{c}\% \text { of } \\
\text { Total } \\
\text { vineyard } \\
\end{array}$ & $\begin{array}{l}\text { Av. Size } \\
\text { Vineyard } \\
\text { (Jeribs) } \\
\end{array}$ & $\begin{array}{c}\% \text { of } \\
\text { Total } \\
\text { Farmland } \\
\text { in Vineyard } \\
\end{array}$ \\
\hline $\begin{array}{r}100 \text { Farms } \\
95 \text { Farms } \\
5 \text { Farms }\end{array}$ & $\begin{array}{r}1920 \\
850 \\
1070\end{array}$ & $\begin{array}{r}100 \\
44 \\
56\end{array}$ & $\begin{array}{r}19.20 \\
8.90 \\
214.00\end{array}$ & $\begin{array}{r}349 \\
295 \\
53\end{array}$ & $\begin{array}{r}100 \\
85 \\
15\end{array}$ & $\begin{array}{r}3.49 \\
3.10 \\
10.60\end{array}$ & $\begin{array}{r}18.17 \\
34.83 \\
5.00\end{array}$ \\
\hline
\end{tabular}




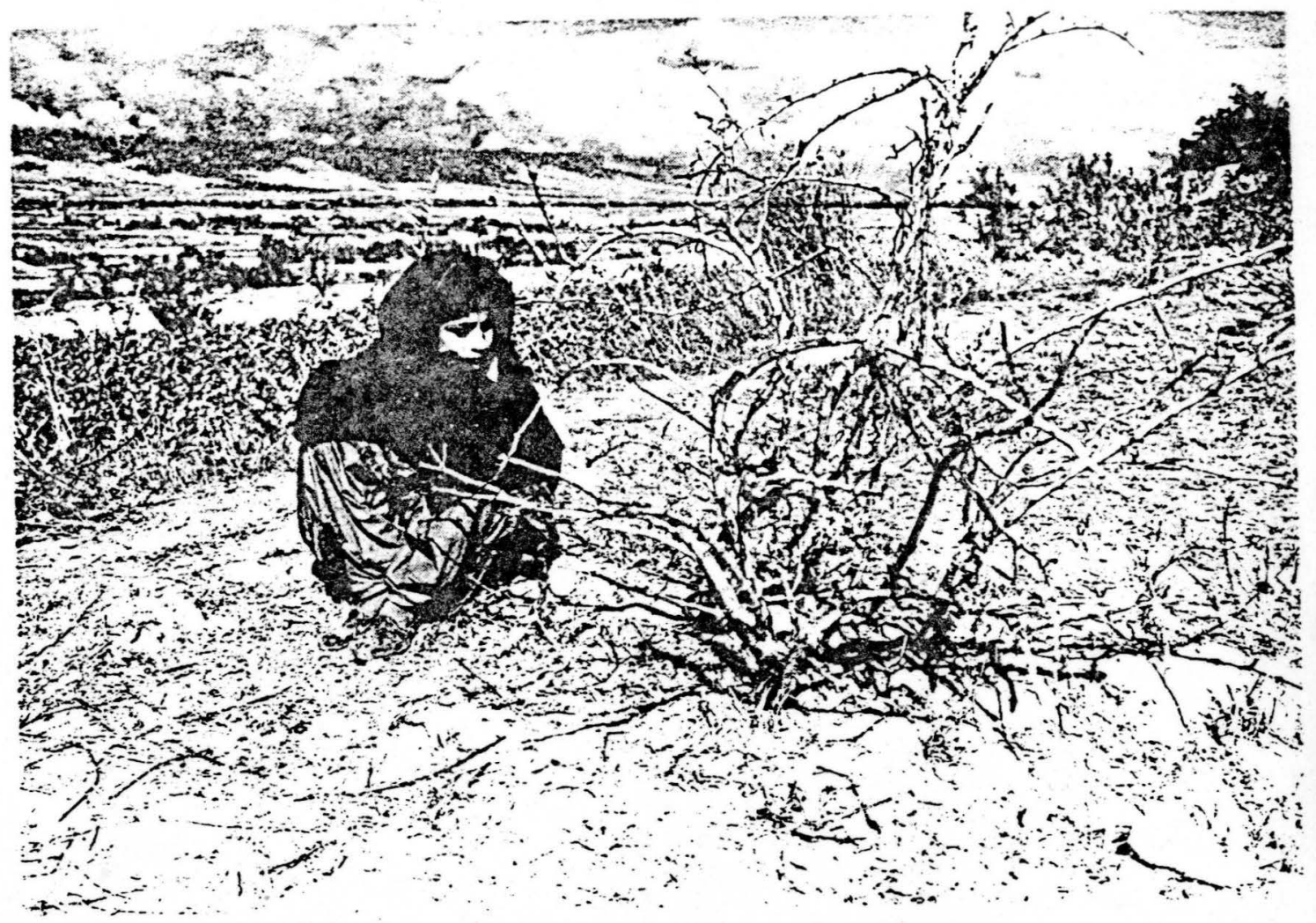

Young grapevine.

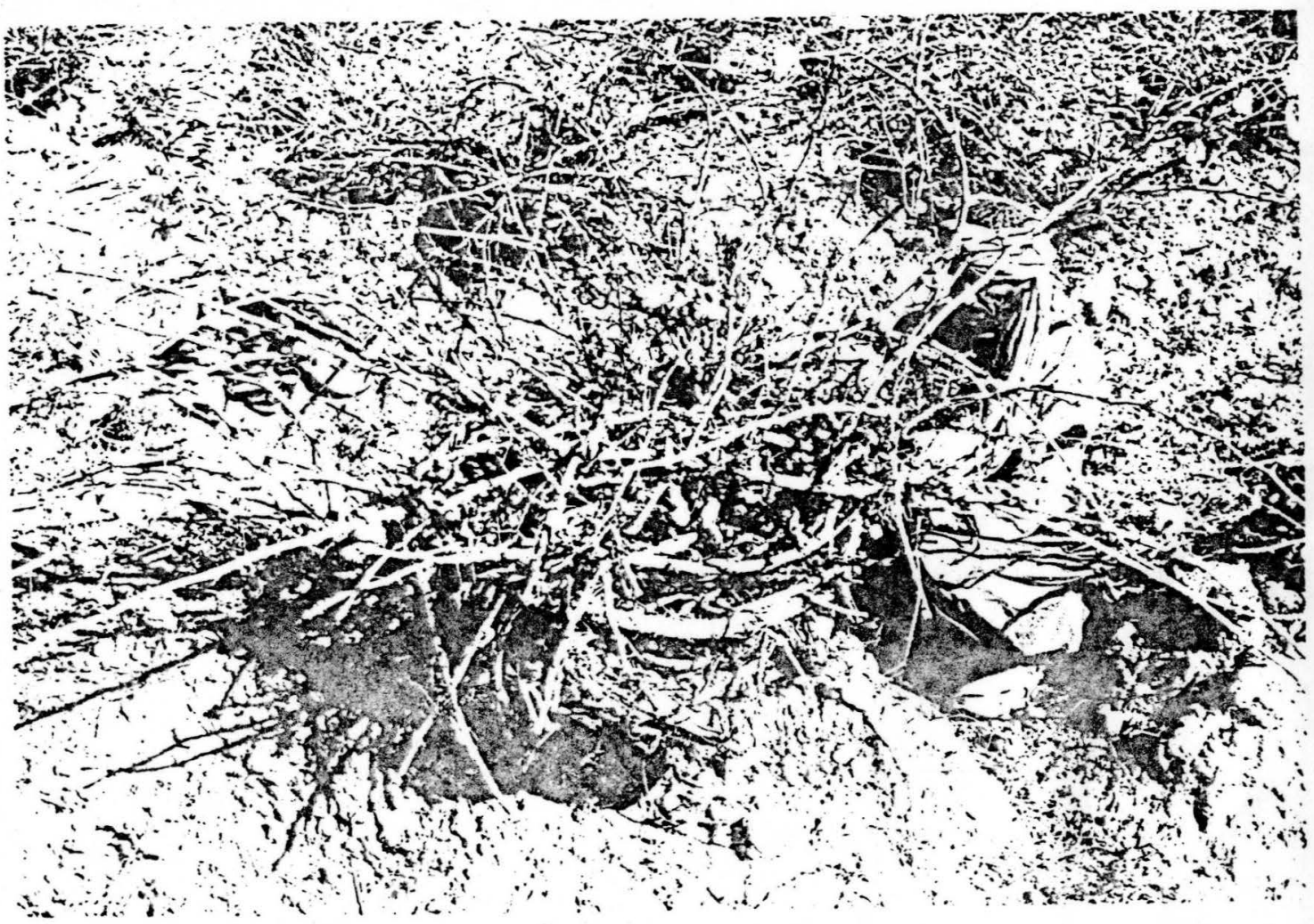

Kature graperine. 
and Labor Requirements

A systematic analysis of production costs for the 100 farmers surveyed was done by first getting an average of each cost ite $m$. When these averages were determined, they were collected into two groups. Those costs which occur even when there are no procuction activities were collected in the group of fixed costs. Cost items which re- late only to production activities were grouped as variable costs. Fixed costs include labor for establishing the vineyard, land tax, depreciation of equipment, interest on the land value, and unpaid family labor. Variable costs include annual hired labor, fertilizer, pesticides, supplies, and miscellaneous costs.

Additional calculations were made to determine the average annual costs per jerib as shown in Table 3.

Table 3. Grape Production-Annual Costs and Labor Requirements Per Jerib, 100 Farms Surveyed; Koh Daman Valley, 1966

\begin{tabular}{|c|c|c|c|}
\hline Cost Items & $\begin{array}{c}\text { Units Applied } \\
\text { Per Jerib } \\
\end{array}$ & $\begin{array}{c}\text { Cost Per } \\
\text { Unit } \\
\end{array}$ & $\begin{array}{l}\text { Av. Cost } \\
\text { Per Jerib } \\
\text { (Afs.) }\end{array}$ \\
\hline \multicolumn{4}{|l|}{ FIXED COSTS: } \\
\hline $\begin{array}{l}\text { Labor to Establish Vineyard } \\
\text { Land Tax } \\
\text { Equipment Depreciation } \\
\text { Interest on Land Value } \\
\text { Unpaid Family Labor } \\
\quad \text { (Operational) }\end{array}$ & $\begin{array}{c}29,000 \text { afs. } \\
32 \text { days }\end{array}$ & $\begin{array}{l}6 \% \\
45 \text { afs. }\end{array}$ & $\begin{array}{r}63.37^{*} \\
17.00 \\
65.80 \\
1740.00 \\
1440.00 \\
\end{array}$ \\
\hline \multicolumn{3}{|c|}{ Total Fixed Costs } & 3326.17 \\
\hline \multicolumn{2}{|l|}{ VARIABLE COSTS: } & 45 afs. & 2115.00 \\
\hline $\begin{array}{l}\text { Animal } \\
\text { Commercial }\end{array}$ & $\begin{array}{l}88 \text { donkey loads** } \\
3.8 \text { seers*** }\end{array}$ & $\begin{array}{c}3.40 \text { afs. } \\
45 \text { afs. }\end{array}$ & $\begin{array}{l}299.20 \\
171.00\end{array}$ \\
\hline $\begin{array}{l}\text { Chemicals for Plant } \\
\text { Protection - Sulphur } \\
\text { Supplies } \\
\text { Miscellaneous }\end{array}$ & .97 seers & 60 afs. & $\begin{array}{r}58.20 \\
172.20 \\
105.00 \\
\end{array}$ \\
\hline \multicolumn{3}{|c|}{ Total Variable Costs } & 2920.60 \\
\hline \multicolumn{3}{|c|}{ TOTAL COSTS } & 6246.77 \\
\hline
\end{tabular}

* This figure was derived from prorating 3825 afs. $(84.5 \times 45)$ over a period of 60 years, expected life of a grapevine. * One donkey load of animal manure averages about 8 seers. $* *$ One seer $=15.58$ pounds. 


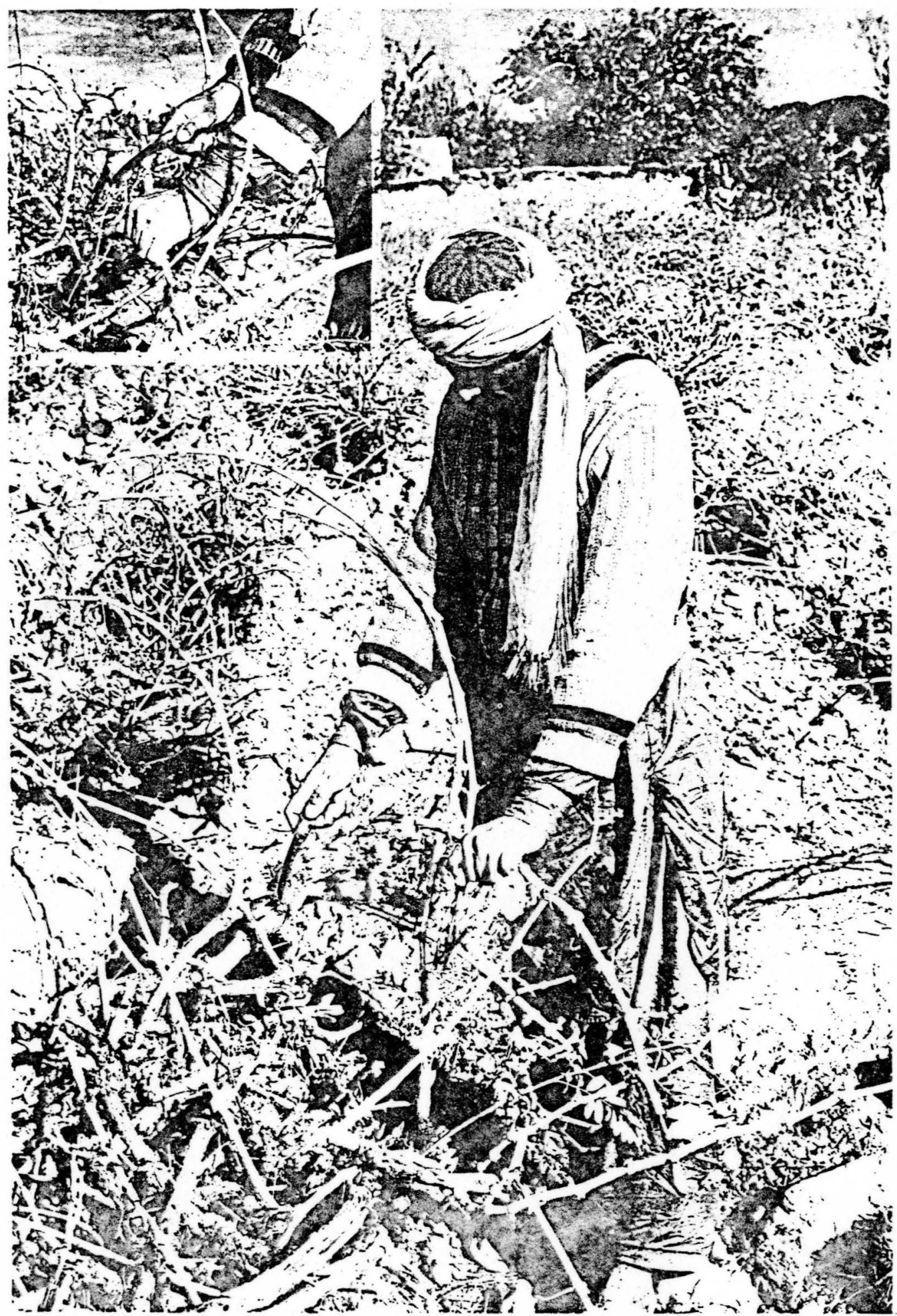

Vine pruning must be done by skilled laborers early in the spring. 
Average labor requirement for establishing one jerib of vineyard was 84.5 days. This is a fixed cost item which was prorated over the life of a grape plant (average of 60 years) in order to determine annual labor costs per jerib. With average wages for an eight-hair day at 45 afs., annual labor cost per jerib is 63.37 afs. This includes labor for preparing the land, planting the young vines, and taking care of them for four years until they come into production.

Determining annual depreciation cost of implements and equipment used in producing grapes was done by itemizing each piece of equipment according to its average estimated value. Value estimates were supplied by the farmers. When an average value of each item of equipment was determined, additional calculations were made to determine average value of the items as a group and the average expected life of the items as a group. In this manner, the annual cost determined was 65.8 afs. for depreciation of equipment. A set of typical equipment used by the grape producers included plow, harrow, hoe, rake, sickle, shovel, kajawa, pruning knife, baskets, boxes and sacks. Average value of the usual set of equipment was about 329 afs. per jerib.

Expected life of these items as a group averaged five years. Average value of the equipment (329 afs.), divided by the average expected life, determined the annual depreciation cost of 65.8 afs. per jerib.

Since family labor has no alternative opportunity for employment, except perhaps in neighboring vineyards, it was included as a fixed cost and itemized as unpaid family laber. The value of family labor used in producing one jerib of grapes was determined by multiplying 32 days (average number of days of family labor used.per one jerib of vineyard) by 45 afs. (average daily wage for an eight-hour day of work in the vineyards). This gave a total unpaid family labor cost of 1,440 afs.

Hired labor costs were included as variable costs. An average of 47 days of hired labor was used in producing grapes from one jerib of vineyard.

Wages ranged from 25 to 63 a fs. per day for an eight-hour day. Grape pickers and other unskilled labor were paid 25 to 35 afs. per day. Shovel cultivatars were paid 35 to 40 afs. per day. Wages above 40 afs. per day were paid to semiskilled and skilled labor such as vine pruners. With wages at 45 afs. for an eight-hour day, average hired labor costs per jerib were 2,115 afs. Total labor requirements for producing grapes from one jerib of vineyard averaged 79 days ( 32 days unpaid family labor +45 days hired labor). By prorating the 84.5 days used in establishing a jerib of vineyard over a period of 60 years, an additional 1.5 days could be added to give an annual labor requirement of 80.5 days per jerib of vineyard.

The method of determining average costs of fertilizer ( 470.2 afs.) and pesticides ( 58.2 afs.) is self-explanatory in the table.

By adding total fixed costs and total variable costs, it was determined that annual costs for producing one jerib of grapes averaged 6,246.77 afs. for the 100 grape-producers surveyed.

\section{Production and Returns}

Grape output per jerib ranged from 50 seers to 630 seers. Average production per jerib was 265.3 seers. With 300 vines per jerib, average yield per vine was .8 seer, or about fourteen pounds.

Table 4 shows the average income from fresh grapes and raisins produced from one jerib of vineyard.

of the 100 farmers surveyed, 33 percent produced and sold only fresh grapes, 40 percent produced and sold any rai- 
Table 4. Average Income Per Jerib From Fresh Grapes and Raisins, - 100 Farms, Koh Daman Valley, 1966

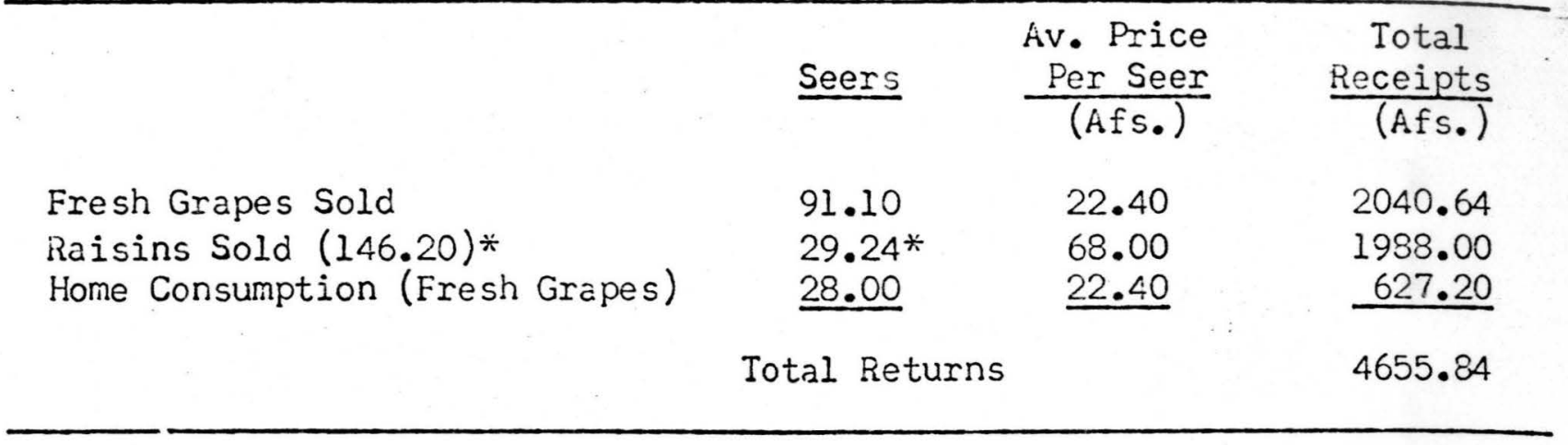

*29.24 seers of Raisins sold are equivalent to 146.20 seers of fresh grapes - Ratio of fresh grapes to raisins is 5 to 1 .

Table 5. Average Costs and Returns Per Jerib of Vineyard For 100 Farms, Koh Daman Valley, 1966

Receipts

Fresh Grape Sales

Raisin Sales

Home Consumption

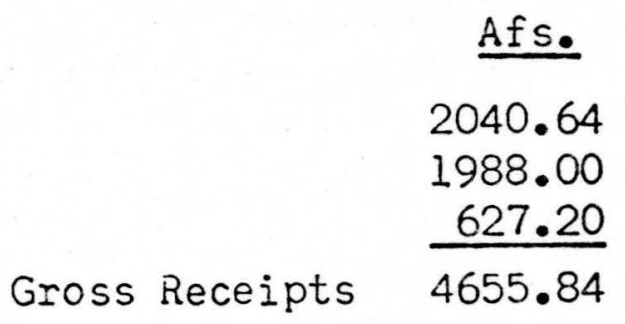

Afs.

2040.64

1987.00

4655.84

\section{Expenses}

Hired Labor (Operational)

Commercial Fertilizer

Animal Manure

Chemicals for Plant Protection

Supplies

Establishing Labor

Equipment Depreciation

Land Tax

Miscellaneous

$$
\begin{array}{r}
2115.00 \\
171.00 \\
299.20 \\
58.20 \\
172.20 \\
63.37 \\
65.80 \\
17.00 \\
105.00 \\
\hline 3066.77
\end{array}
$$

3066.77 


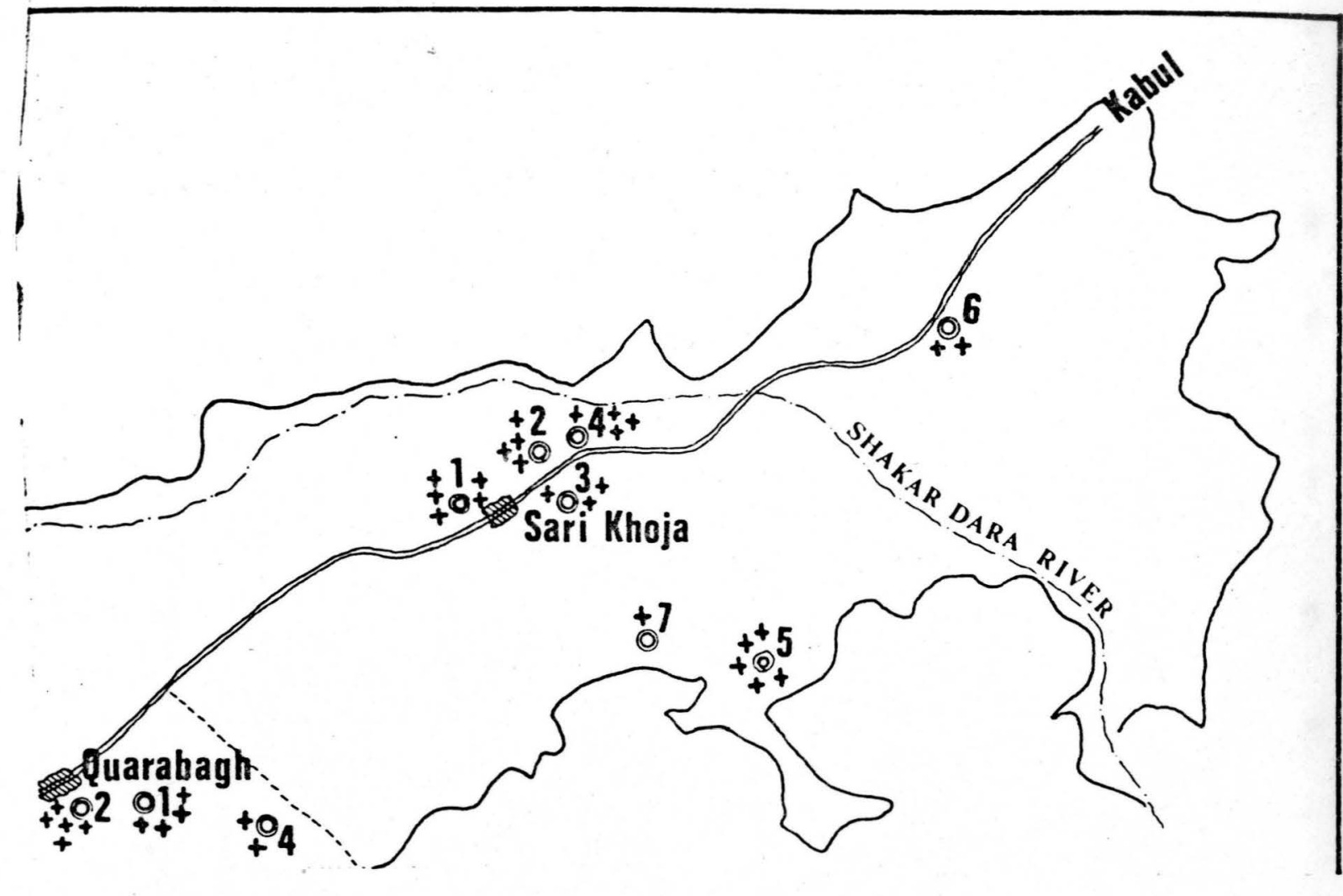

- Red raisins (kishmish-i-sorkh) are obtained by drying fresh grapes in the sun.

v

KOHDAMAN VALLEY

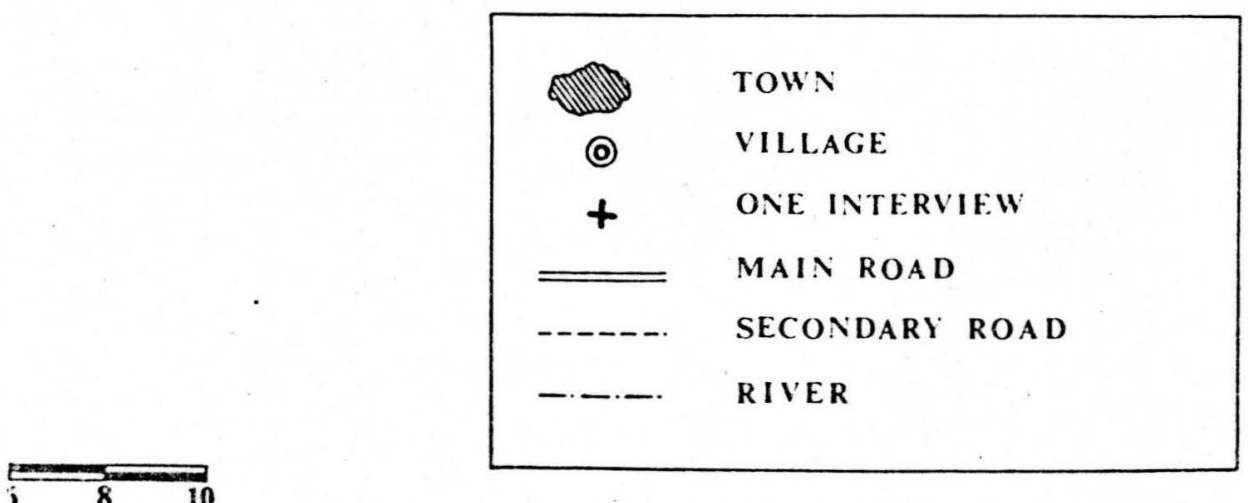

AFGHANISTAN \& UNITED

PPROXIMATED

\section{NATIONS SPECIAL FUND}

\section{LANO \& WATER RESOURCES}

- Shadow-dried "sayagie" raisins are obtsined by drying grapes in indoor drying chambers. 
Summary and Recommendations

Grapes are an important commercial crop for Afghanistan's domestic market as well as for export. In addition to supplying information on costs and returns of grape production, this pilot study should provide guidelines for future economic research of other major agricultural commodities. Important input-output data for agricultural production in Afghanistan are extremely limited.

Vineyards of the Koh Daman Valley are small, averaging 3.5 jeribs or a little more than 1.5 acres. Family labor is sufficient for this size vineyard except during the peak of harvest. lages for hired labor are rather high compared to per-jerib returns to family labor. liore studies should be made to find ways to maximize efficiency of labor use.

Irrigation water is essential, but it is limited in certain parts of the valley. Studies to determine the most timely application of water, and development of a more efficient system of canals and ditches, would facilitate more effective use of water.

Cultural practices and farm implements are primitive, and average grape yields are low. Yield per vine averages about 14 pounds as compared to an average of 22 pounds per vine in countries using mocern production practices.

The wide range in output per jerib (50 to 630 seers) implies the possibility of increasing production significantly and raising the net income, which now averages $1,589.07$ afs. $(\$ 21.18$ ) per jerib. A minimum of tests and experiments with modern grape production methods will determine which practices are best adapted to grape production in Afghanistan. When appropriate practices are determined, the farmers shaild be shown, through carefully planned demonstrations, how to apply them. The object would be to determine and encourage adoption of practices which have the greatest potential for increasing perjerib returns with a minimum of additiona' costs.

Grape producers in the Koh Daman Valley seem to be very receptive to the adoption of modern cultural practices and the use of fertilizers and pesticides. One of the leading farmers in the Village of Quarabagh Bazaar is cooperating with the Faculty of Agricul ture staff on an experimental-demonstration project. He permitted a small vineyard to be used (with assurance of nominal compensation) for experimenting with and demonstrating cultural practices commonly used in the most modern grape-producing cauntries. Dr. Bergelin of the Faculty of Engineering and Mr. John Perry, a food processing specialist with the Ministry of Commerce, are also cooperating in this project. They are experimenting with and demonstrating certain grape-drying processes.

Extension efforts in grape production similar to this experimental-demonstration project have a higher potential (in terms of increased profits to farmers and foreign exchange earnings) than those in any other crop; with the possible exception of wheat, where the combination of price incentives and concerted extension efforts have aiready produced significant results. 
Sumnary and Recommendations

Grapes are an important commercial crop for Afghanistan's domestic market as well as for export. In addition to supplying information on costs and returns of grape production, this pilot study should provide guidelines for future economic research of other major agricultural commodities. Important input-output data for agricultural production in Afghanistan are extremely limited.

Vineyards of the Koh Daman Valley are small, averaging 3.5 jeribs or a little more than 1.5 acres. Family labor is sufficient for this size vineyard except during the peak of harvest. lages for hired labor are rather high compared to per-jerib returns to family labor. liore studies should be made to find ways to maximize efficiency of labor use.

Irrigation water is essential, but it is limited in certain parts of the valley. Studies to determine the most timely application of water, and development of a more efficient system of canals and ditches, would facilitate more effective use of water.

Cultural practices and farm implements are primitive, and average grape yields are low. Yield per vine averages about 14 pounds as compared to an average of 22 pounds per vine in countries using modern production practices.

The wide range in output per jerib (50 to 630 seers) implies the possibility of increasing production significantiy and raising the net income, which now averages 1,589.07 afs. (\$21.18) per jerib. A minimum of tests and experiments with modern grape production methods will determine which practices are best adapted to grape production in Afghanistan. When appropriate practices are determined, the farmers should be shown, through carefully planned demonstrations, how to apply them. The object would be to determine and encourage adoption of practices which have the greatest potential for increasing perjerib returns with a minimum of additionar costs.

Grape producers in the Koh Daman Valley seem to be very receptive to the adoption of modern cultural practices and the use of fertilizers and pesticides. One of the leading farmers in the Village of Quarabagh Bazaar is cooperating with the Faculty of Agricul ture staff on an experimental-demonstration project. He permitted a small vineyard to be used (with assurance of nominal compensation) for experimenting with and demonstrating cultural practices commonly used in the most modern - grape-producing countries. Dr. Bergelin of the Faculty of Engineering and iv. John Perry, a food processing specialist with the Ministry of Commerce, are also cooperating in this project. They are experimenting with and demonstrating certain grape-drying processes.

Extension efforts in grape production similar to this experimental-demonstration project have a higher potential (in terms of increased profits to farmers and foreign exchange earnings) than those in any other crop; with the possible exception of wheat, where the combination of price incentives and concerted extension efforts have already produced significant results. 


\section{MARKETING}

Part II

Introduction

The second phase of this combined production - marketing study involved five separate investigations:

1. A survey of retail bazaar prices in the Koh Daman Valley.

2. A survey of truckers loading grapes in the Koh Daman area.

3. A study of the wholesale fruit bazaar in Kabul.

4. A survey of grape bazaars in Kabul.

5. Compilation of grape and raisin export data.

The overall objective was to determine as much as possible about the market structure and prices for grapes and raisins.

Retail Prices in the Koh Daman Valley

On November 9, 1966 a small survey crew made 93 price observations at retail bazaars in the producing area. Results are shown in Table 6.

Prices were higher for better grades as would be expected. Also, prices in the grape producing area were generally lower than prices in Kabul as shown in Table 6 by the comparable Kabul prices. Kabul prices will be discussed in detail in a subsequent section.

If a bias exists in the Koh Daman retail prices, it is $8 \mathrm{n}$ upward bias. Prices were determined at bazaars on or near the main highway. Also, there is a recognized tendency for shopkeepers to ask a higher price than they expect to receive. However, the enumerators were Afghan Faculty members and undoubtedly made reasonable determinations in most cases.

Wost, if not all, the grapes sold in Koh Daman Valley bazaars from Hassein Kot to Charikar and beyond are grown within a few kilometers of the retail bazaar and are transported'by men or donkeys
Interviews iith Truckers

Loading Grapes inthe Koh Daman Valley At the same time retail prices were determined in the grape-producing area (Nov.9), another small crew interviewed truckers who were loading grapes at established pick-up stations for transport out of the area. Objectives were to determine:

A) destination of grapes being loaded

B) prices paid to producer

C) transportation costs and other pertinent information which might appear in such interviews

All truckers were friendly and did not seem to attempt to withhold information. Seventruckers were interviewed using an interview guide. Table 7 shows prices paid to producer.

The wice variation in price was explained by the fact that some, but not all, vineyarcis had suffered freeze damage, so there was a wide range in quality. In addition, at least two truck drivers reported that certain contractuai arrangements between Afghanistan and India had been terminated :!ithin the past two days. As a result, the price per seer on the Fakistan market dropped considerably.

Six of the seven truckers interviewed were bound for the Customs clear ing house in Kabul and the cestination of their grapes vas Peshawar. In most cases, trucks were met at Customs by an agent from Peshawar who took the grapes on a consignment basis.

The seventh truck was hauling to the Kabul wholesale market. There were three varieties of grapes on this truck, gathered at different locations in the valley.

Iransportation costs (afs. per seer) to Kabul are shown in Table 8 .

There was general agreement on transportation costs, which appear to be standardized. 
Table 6. Retail Price Per Pow of Six Types of Grapes in the Koh Daman Area By Grade

\begin{tabular}{|c|c|c|c|c|c|c|c|c|c|c|c|c|}
\hline \multirow[t]{2}{*}{ Grade } & \multicolumn{2}{|c|}{ Kishmishi } & \multicolumn{2}{|c|}{ Hussaini } & \multicolumn{2}{|c|}{ Kata } & \multicolumn{2}{|c|}{ Gholadan } & \multicolumn{2}{|c|}{ Abjosh } & \multicolumn{2}{|c|}{ Monaga } \\
\hline & $\mathrm{N}^{*}$ & $\underline{\mathrm{Av}}$. & $\mathrm{N}^{*}$ & Av. & $\mathrm{N}^{*}$ & Ave & $\mathrm{N}^{*}$ & Av. & $\mathrm{N}^{*}$ & Av. & $N^{*}$ & Av. \\
\hline Good & 5 & 3.2 & 5 & 3.3 & 3 & 2.0 & - & - & 1 & 3.5 & 1 & 2.5 \\
\hline Fair & 7 & 2.6 & 2 & 3.0 & 3 & 2.0 & 1 & 2.0 & - & - & 1 & 2.0 \\
\hline Poor & 1 & 2.0 & 2 & 2.0 & 5 & 1.7 & 2 & 1.7 & - & - & - & - \\
\hline All Grades & 13 & 2.8 & 9 & 2.9 & 11 & 1.9 & 3 & 1.8 & 1 & 3.5 & 2 & 2.2 \\
\hline $\begin{array}{l}\text { Comparable } \\
\text { Kabul Prices }\end{array}$ & 91 & 3.3 & 78 & 3.6 & 23 & 2.4 & 8 & 1.9 & 33 & 3.6 & - & - \\
\hline
\end{tabular}

$N^{*}=$ number of observations 


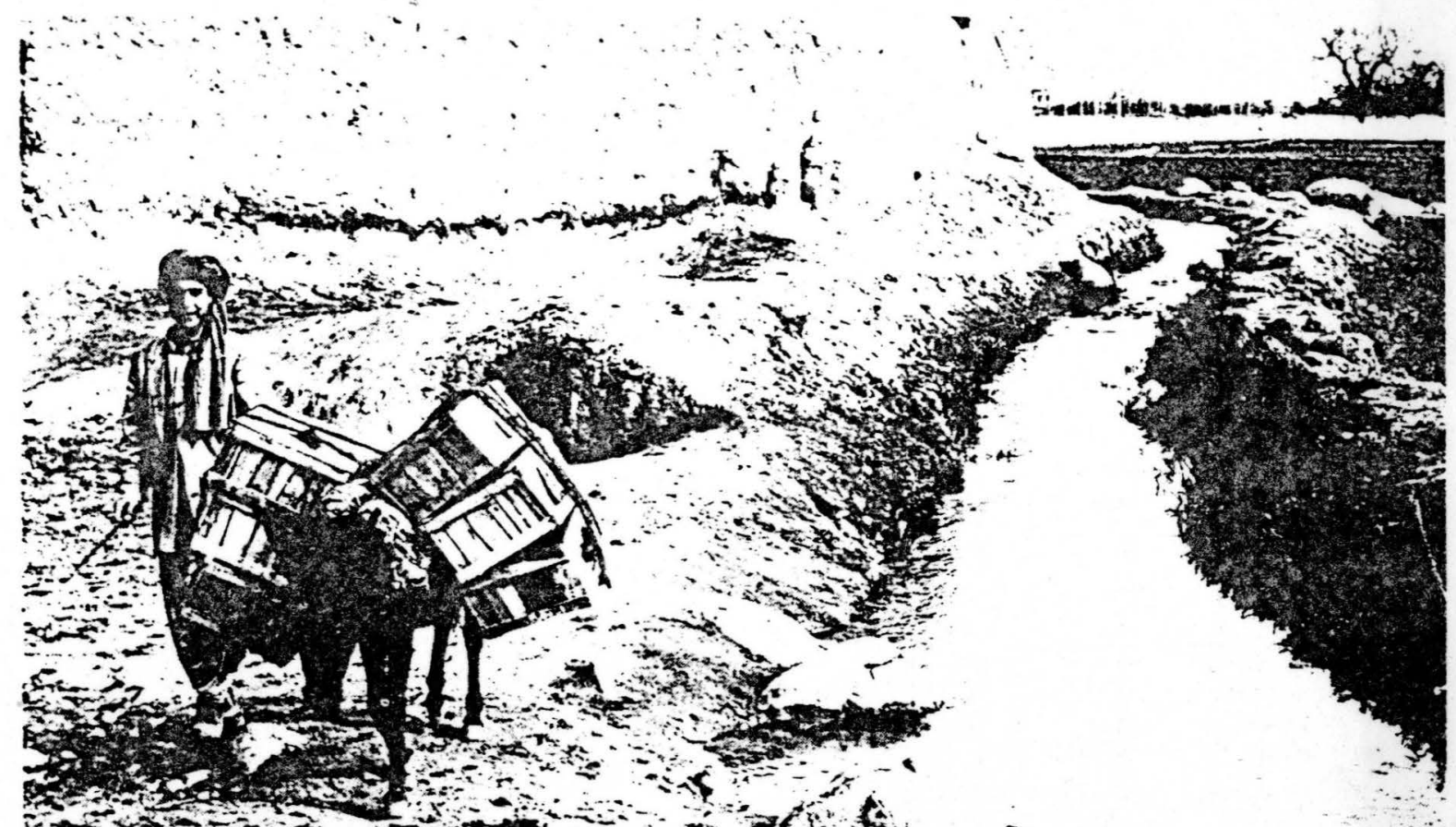

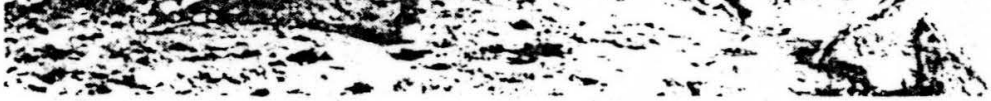

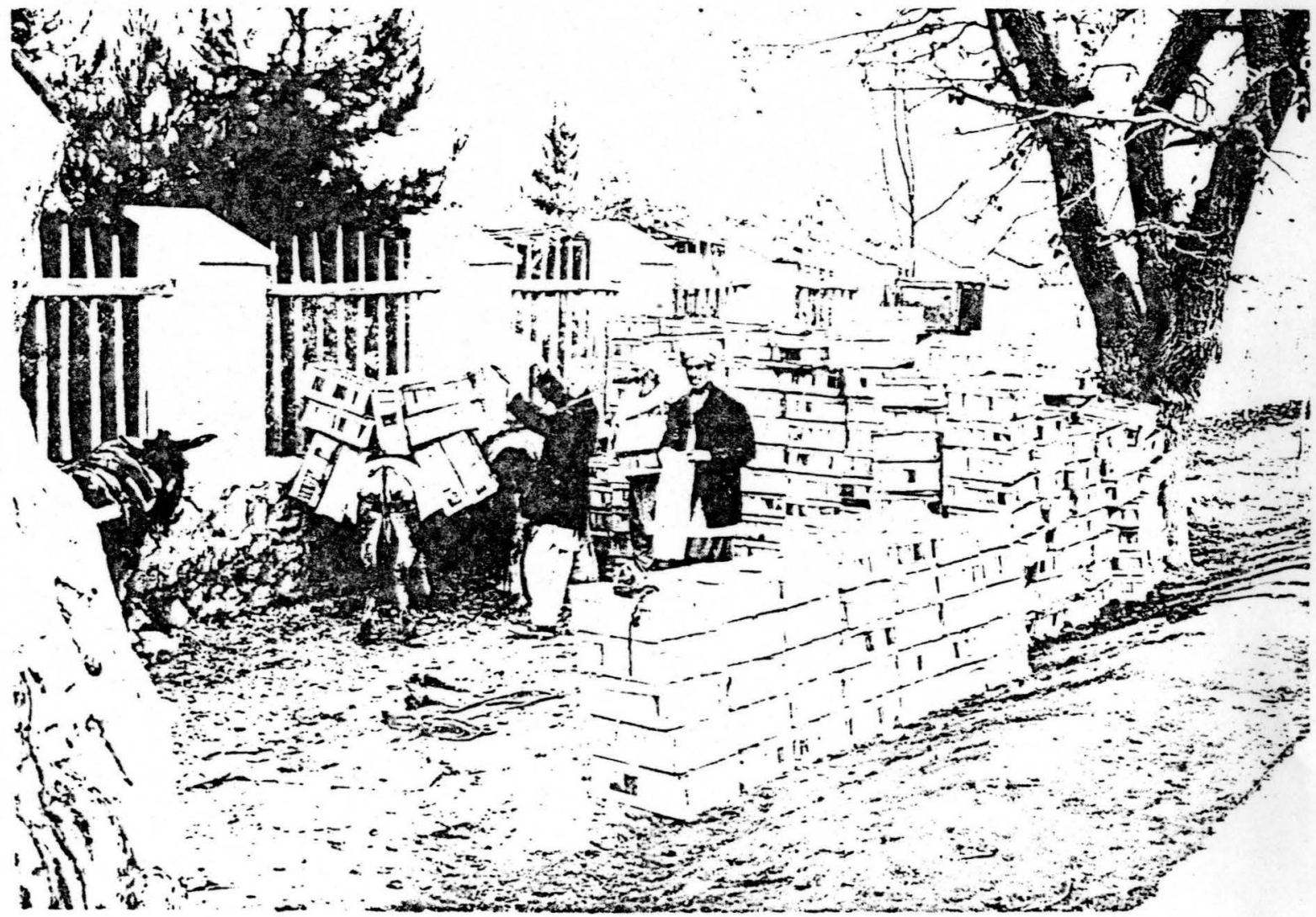

Grapeś grown in Koh Daman vineyards are brought on aonkeys to collection centers near the highway. 
Table 7. Prices Paid to Producer (Afs. Per Kharwar*) For Four Types of Grapes

\begin{tabular}{|c|c|c|}
\hline \multirow[b]{2}{*}{ Type of Grape } & \multicolumn{2}{|c|}{ Price } \\
\hline & Range & Average \\
\hline Kishmishi & $2000-4000$ & 2712 \\
\hline Kata & $1400-2000$ & 1740 \\
\hline Gholadan & $1300-2000$ & 1650 \\
\hline Abjosh & & $3000 * *$ \\
\hline
\end{tabular}

Table 8. Transportation Rates for Grape Hauling From the Koh Daman Valley to Kabul

\begin{tabular}{lllllll}
\hline From & Afs. $\frac{\text { Cost }}{\text { Per Seer }}$ & Miles & From & Cost & Miles \\
\hline Hassein Kot & 1 & 15.5 & Kalakam & 1 & 24.0 \\
Sarak Goldara & 1 & 18.0 & Baghe Iraq & $1-1 / 2$ & 27.0 \\
Sarai Khoja & 1 & 21.0 & Charikar & 2 & 37.5 \\
\hline
\end{tabular}

There was general agreement on transportation costs, which appear to be standardized. 


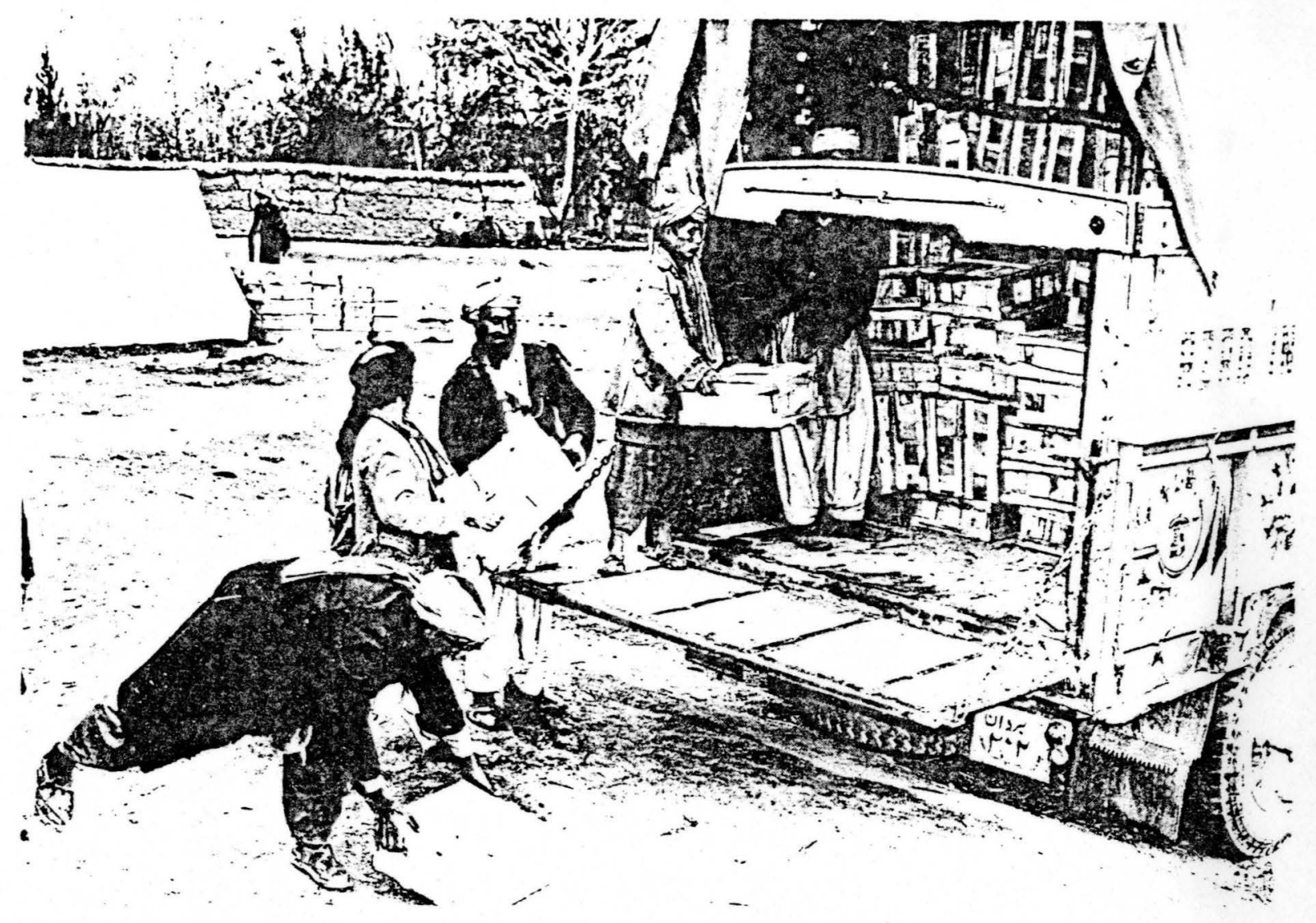

Grapes being loaded on trucks at a collection center for transport to Kabul.

Kishnishi grapes were being loaded by all trucks except the one at Sarak Golciara, so apparently these grapes are grolvn tinroughout the valley.

Kata variety were being loaced only at Hassein Kot, Sarak Goldara and Sarai Khoja - the areas nearest to Kabul. The trucker at Baghe Irac mentioned that mostly $K$ ishmishi grapes were grown in that area.

Gholadan grapes were being loaded only at Hassein Kot and Sarai Knoja and the Abjosh variety at Eaghe Iraq.

Grapes for export are packaged in 2 seer lugs while grapes for Kabul are packaged in 5 seer crates. Large numbers of both kinds of containers were observed throughout the area, awaiting shipment (or empties waiting to be filled); but by far the majority seemed to be the ti:o seer lugs.

The ucual arrangement seems to be for a niddieman (in some cases - the trucker) to purchase grapes in the field from the vineyard owner. He then arranges to have them picked, packaged and transported (usually by donkey or camel) to the pick-up station at the highway. 


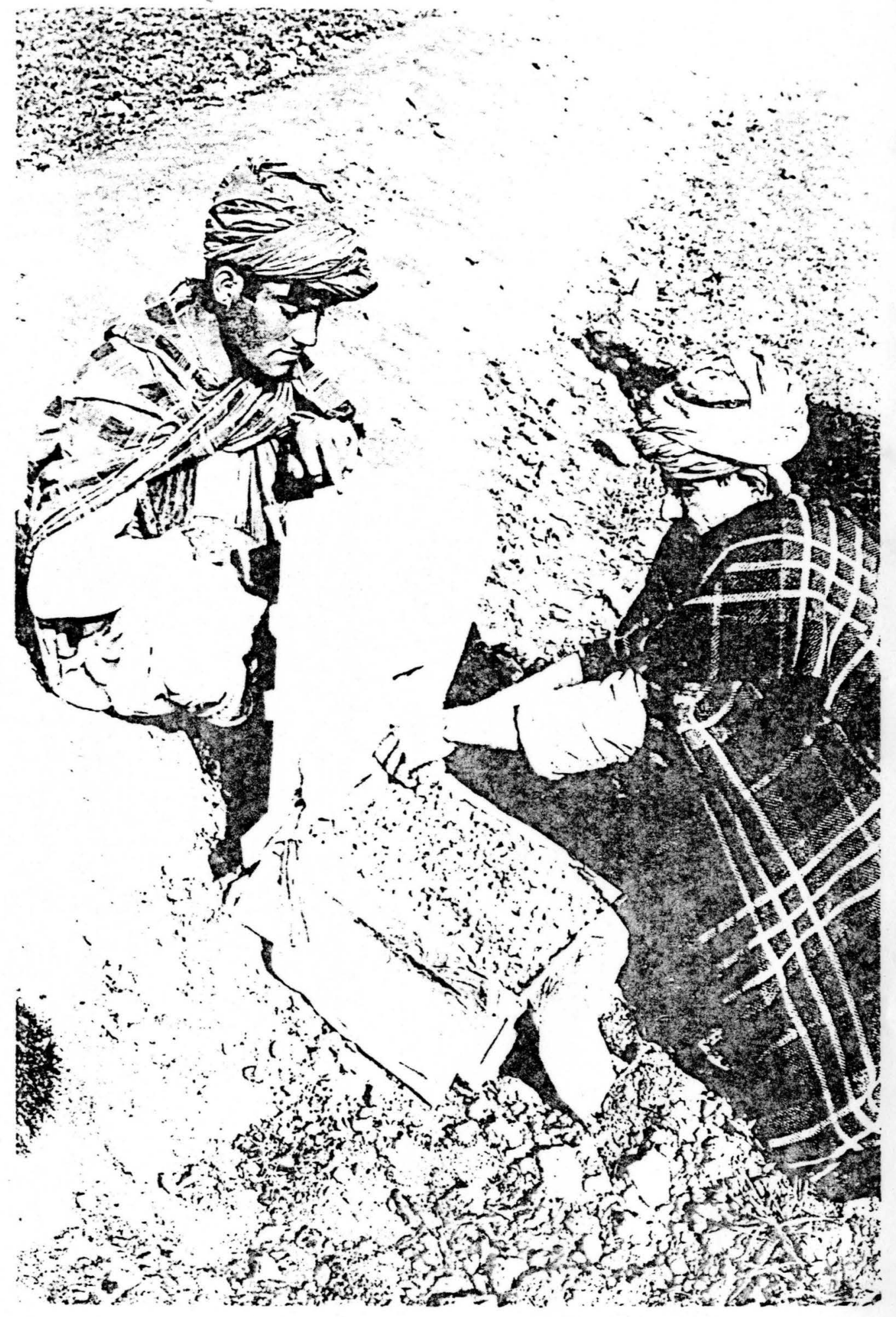

\section{Kishmishi grapes for export are packed cerefully in two-seer wocken bores.}


The Kabul Wholesale Fruit Warket

A visit was macie to the Kabul Fruit and Vegetable wholesale market at Share-Nau. The purpose of the visit was to determine as much as possible about the organization of the market, wholesale prices and origin of grapes.

The market area covers about 21,000 square meters or eleven jeribs. The main market area consists of three rows of open sheds where produce is stored until sold. The following is a list of produce items being sold in the wholesale market:

$\begin{array}{ll}\text { grapes } & \text { pomegranates } \\ \text { melons } & \text { pumpkins } \\ \text { squash } & \text { tangerines } \\ \text { onions } & \text { potatoes } \\ \text { pears } & \text { green beans } \\ \text { oranges } & \text { cauliflower } \\ \text { quince } & \text { dried mulberries } \\ \text { peppers } & \text { bananas } \\ \text { apples } & \text { sugar cane stalks }\end{array}$

Retail merchants of all sizes come to the market to buy grapes which they carry out on foot, bicycle, cart, etc. During the interviews, three types of grape merchants were identified:

1. Contractor - these people contract with the grower for his produce before the grapes mature. They bring the grapes to market and sell them themaslvea.
2. Vineyard Owners (growers) - they bring their grapes to market and sell them.

3. Commission Sellers (Agents) - they sell grapes for both contractors and growers for a commission.

Considerable difficulty was experienced in determining prices, for the following reasons.

First - there are no set prices in this market; all prices, both purcha se and sales prices, were determined by bargaining.

Second - quality of grapes was hard to determine because most of the packing crates and lugs were not open.

Third - purchase price and sales price were usually calculated in different units of measure, such as afs. per kharwar for purchases and afs. per seer for sales.

All the grapes found in the market this day were from the Koh Daman Valley area. It seemed that a margin of 5 afs. per seer was most usual. As mentioned earlier, price data vere difficult to obtain but the ranges of purchase and sales prics show in Table 9 were the concensus of many wholesale merchants. (iven an attempt was made to interview any particularmerchant, all the other merchants within earshot would gather around and contribute to the interview).

Table 9. Price Ranges for Grapes in the Kabul Wholesale liarket

Type of Grape $\quad$ Purchase Price*. Sale Frice*

Kata

Kishmishi

Hussaini

Che shmi-gow
27

40-55

45-50

22
$30-32$

$50-60$

$50-55$

26

*Afs。 per seer 
Several merchants in the wholesale market compound considered themselves as combination wholesaler-retailers they would sell small lots, crates or two-seer lugs to anyone.

Kabul Retail Fresh Fruit Market

The schedule used in this phase of the study was designed to show: 1) retail prices in large, medium and small bazaars, 2) prices paid for grapes by the retail sellers throughout the fresh grape sea son (Asad through Aqrab), 3) source of grape and 4) type of seller (retail, wholesale or combination retail-iholesale).

After the schedule was pretested, eleven enumerators were trained and assigned to work in specific locations which covered most areas of the city and which were known to contain several fresh fruit. retail bazaars. Three supervisors went with the eleven enumerators. Eighty-nine schedules were obtained, each from a different bazaar.
After enumeration, schedules were edited and data were hand tabulated. Results are as follows:

Retail Prices: Table 10 shows retail prices in afs. per pow for three grades and six types of grapes.

Other types of grapes observed during enumeration were Chingul-Khani, Kandahari and Chesme-Gow. Price data for these types are not presented in $\mathrm{T}$ able 5 because only a few observations were made. Kandahari grapes are quite common during the first part of the grape season, as will be shown later.

When retail grape prices were tabulated according to size of seller, as shown in $\mathrm{T}$ able 11 , results were not exactly as expected. Larger sellers usually received a higher price than did the smaller sellers. This is probably because the small sellers usually sold the poorer quality grapes and also because they had the poorer locations.

Of the 90 sellers interviewed, at least nine but not more than 17 were

Table 10. Retail Prices of Six Types of Grapes by Quality of Grapes - Kabul, November 7, 1966

\begin{tabular}{|c|c|c|c|c|c|c|c|c|}
\hline \multirow{3}{*}{ Iype } & \multicolumn{6}{|c|}{ Price - Afghanis Per Pow } & & \\
\hline & \multicolumn{2}{|c|}{ Good } & \multicolumn{2}{|c|}{ Fair } & \multicolumn{2}{|c|}{ Poor } & \multicolumn{2}{|c|}{ All Grades } \\
\hline & $\mathrm{N}^{*}$ & $\mathrm{Av}$ & $N^{*}$ & Av & $\mathrm{N}^{*}$ & Av & $\mathrm{N}^{*}$ & Av \\
\hline Hussaini & 33 & 3.91 & 35 & 3.47 & 10 & 2.95 & 78 & 3.59 \\
\hline Kishmishi & 27 & 3.59 & 42 & 3.22 & 22 & 2.71 & 91 & 3.29 \\
\hline Abjosh & 17 & 3.70 & 14 & 3.59 & 2 & 2.50 & 33 & 3.59 \\
\hline Kata & 8 & 2.88 & 10 & 2.25 & 5 & 2.10 & 23 & 2.44 \\
\hline Monaqa & 4 & 4.13 & 1 & 4.00 & 2 & 2.50 & 7 & 3.65 \\
\hline _ Gholadan & - & - & 4 & 2.08 & 4 & 1.85 & 8 & 1.95 \\
\hline
\end{tabular}

$*_{\mathrm{N}}=$ number of observations 
combination wholesaler-retailers. Ih is means that they sold grapes (sometimes on a consigment basis) to small retailers for resale in other areas. In all likelihood, they sold their poorer quality grapes to the other retailers.

kiajor source of supply of grapes was primarily the wholesale fruit bazaar discussed previously. The breakdown of the source of supply is as follows:

\begin{tabular}{lrr} 
Direct from Grower & 1 & 1 \\
Wholesaler & 80 & 89 \\
Another Retailer & 4 & 5 \\
Trucker & 3 & 3 \\
Sellers Own Vineyard & 2 & 2 \\
\cline { 2 - 3 } & & \\
TOTAL & 90 & 100
\end{tabular}

Prices paid for grapes by retail sellers were determined by inquiring about prices paid during Asad, Sonbula, líaizon and Aqrab. As would be expected, prices are relatively high at the beginning of the season, go down until grapes become more scarce at the end of the season, when the price again rises.
Table 12 shows average grape prices by month for eight varieties of grapes and for all varieties combined.

Most sellers bought several varieties of grapes during the season. Kandahari and Sia Kandahari grapes were most popular at the beginning of the sea son (during Maizon and Acrab). Kis hmishi are also quite popular at the beginning of the season, but are most popular later on. Kata are late season grapes almost exclusively and the Abjosh, Gholadan and Monaqa were not commonly found during the first two months of the season (Asad and Sonbula).

If number of observations of grapes purchased is used as an indicator, Kishmishi (similar to Thompson Seedless) are the most popular grape overall and are nearest to being an "all season" variety. Hussaini is next in popularity and is most common during the last three months of the season. After Kishmishi and Hussaini, the popularity range seems to be Abjosh, Kandahari, Kata, Monaqa, Gholadan and Sia Kandahari. Other types observed in small quantities were Shunder Khani, Rucha, Chingul Khani, Gerdi, Cheshmi-gow, Sia Gul and Lal.

Table 11. Retail Price of Five Types of Grapes by Size of Seller - Afs. Per Pow

\begin{tabular}{lccc}
\hline & Large $^{*}$ & Niedium* $^{*}$ & Small* $^{*}$ \\
\hline Hussaini & 3.92 & 3.49 & 3.00 \\
Kishmishi & 4.05 & 3.28 & 2.71 \\
Abjosh & 3.70 & 3.58 & 2.50 \\
Kata & 3.00 & 2.15 & 2.00 \\
Monaqa & 4.12 & - & 2.70 \\
\hline
\end{tabular}

*There were 16 large sellers, 35 medium and 39 small sellers in the sample. 
Table 12. Purchase Price (Afs. Per Seer) of Urapes by lionth, by Eight Varieties and Average of All Varieties

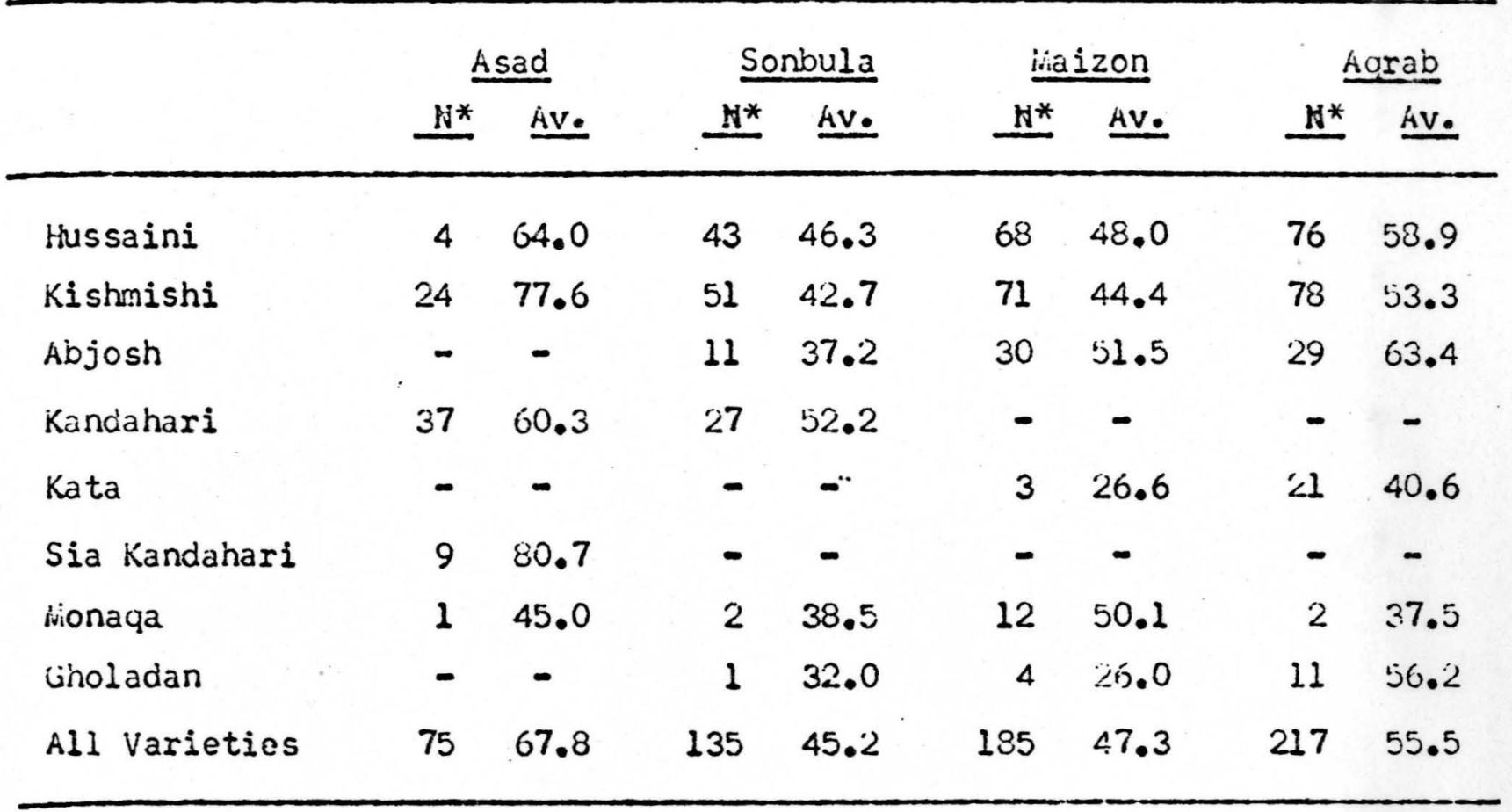

$*_{N}=$ number of observations

Sia Kandahari and Kandahari grapes are the most expensive varieties while Kata is least expensive.

The range from the most expensive to least expensive, accorciing to average purchase price per seer for the entire season, is as follows:

\begin{tabular}{ll} 
Sia Kandahari & 80.7 \\
Kandahari & 57.0 \\
Abjosh & 54.2 \\
Hussaini & 52.3 \\
Kishrnishi & 50.7 \\
Gholadan & 47.1 \\
lionaqa & 47.0 \\
Kata & 38.8 \\
\hline
\end{tabular}

Overall Average 52.2

Kandahari and Sia Kandahari grapes are early season varieties from Southern Afghanistan and are higher in price because of transportation costs and early season demand. (The same varieties are grown in the KohDaman Valley, but these mature later).

Prices paid by retailers follow the same general pattern as prices reœived, i.e. they are highest at the beginning of the season, lower during the months of Sonbula and liaizon and $r$ ise again toward the end of the season. Consult Table 12 for details.

There seems to be approximately 2.3 afs. per seer difference between purchase and sales price - relatively small margin of 4.5 percent. This was determined by comparing purchase and sales prices of Abjosh, Hussaini, Kishnishi and Kata grapes - the only varieties with sufficient observations in both categories. 

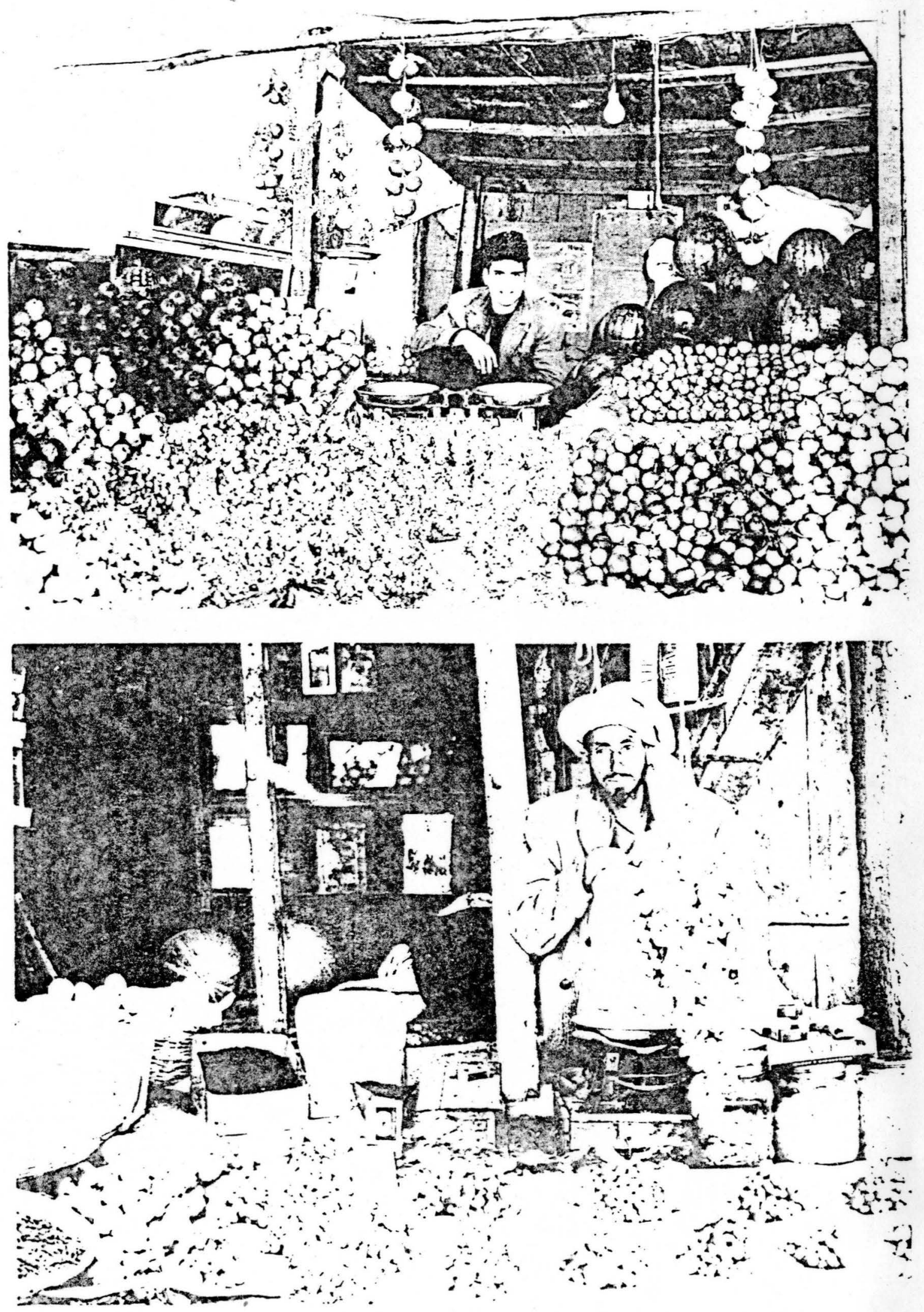

amplea of large (i) and mentim (P) Erape sellers. 
Grape marketing seems to be fairly well organized, at least for the Kabul retailmarket and for Export. Although there is no apparent authoritative institution for exchange of supply, demand and price information, word of mouth between producing and consuming areas a ppears to be quite adequate. Prices seem to be quite uniform and transportation, hanciling and packing costs appear to be standardized in a free market structure. Government regulations and protocol agreements do affect exports, however. Regulation of exports and weather conditions are probably the two major uncertainties.

\section{Export of Grapes}

Afghanistan exports grapes to Pakistan, India and the USSR. Exports have been steacily increasing inboth quantity and value since 1962 (1341).

Kishmishi is by far the most popular variety for export, amauting to 95-99 percent of total fresh grapes going out of the country. Kandahari, Gholadan and Hussaini are exported in smaller àmounts.

.Pakistan is the most important buyer of Afghan grapes, India is second and the USS.' is third. However, the USSR has made no purchases of ifghan grapes since 1962 when they took 95 percent of all fresh grapes exported.

The following table shows amount and value of exports, varieties exported and destination of exports from 1961 to 1964 .

\section{Export of Raisins}

Afghan raisin exports account for a larger volume of foreign exchange than do fresh grape exports. The following table shows amount and value of exports, types of raisins exported and destination.

Raisins are sent to many more countries than fresh grapes because they are less perishable. Price per kilogram has been increasing but seems to be somewhat irregular from year to year. Green raisins account for the largest volume of exports with red raisins running a close second.

\section{Summary}

Fresh Fruits and Dried Fruits and Nuts combined are Afghanistan's largest and most important export item. Domestically, they are an important consumption item.

Grapes are probably the single most

important fruit crop, being grown over much of the country... Major producing areas include the Koh Daman Valley and relatedareas, Parwan Province, Kapisa Province, a large part of the Arghandab Valley, and the Southwestern part of the Logar Valley.

The domestic fresh grape market appears to be well organized with respect to pricing and supply. Investigations revealed that prices were relatively uniform with respect to geographic 10cation (in proportion to distance from Charikar to Kabul) and that seasonal fluctuations in price occurred as would be expected due to the relationships between supply and demand. The transportation system seemed to be fairly well organized. Short hauls from vineyard to nearby market or pickup station were usually by donkey and longer hauls were by truck. Iransportation rates appeared to be quite uniform.

The usual marketing channel was grower to middleman (or middlemen) to retail seller or exporter. Very few grapes were retailed in Kabul by the growers themselves.

Most of the grapes in Kabul were sold through a large wholesale fruit market. Four types of middlemen were identified in the wholesale market. 
Table 13. Fresh Grape Exports - 1961 - 1964

\begin{tabular}{|c|c|c|c|c|c|c|c|c|c|c|}
\hline \multicolumn{4}{|c|}{ Exports } & \multicolumn{4}{|c|}{ Varieties Exported } & \multicolumn{3}{|c|}{ Destination } \\
\hline \multirow{2}{*}{ Year } & \multirow{2}{*}{$\frac{\text { Amount }}{\text { (Kilogram) }}$} & \multicolumn{2}{|c|}{ Value (Afs.) } & \multicolumn{4}{|c|}{$\begin{array}{l}\text { Percent of total yearly grape } \\
\text { exports by weight }\end{array}$} & \multicolumn{3}{|c|}{$\begin{array}{l}\text { Percent of total } \\
\text { yearly exports }\end{array}$} \\
\hline & & Total & $\begin{array}{l}\text { Afs. } \\
\text { per } \\
\text { Kilo }\end{array}$ & $\begin{array}{l}\text { Kish- } \\
\text { mishi }\end{array}$ & $\begin{array}{l}\text { Kanda- } \\
\text { hari }\end{array}$ & $\begin{array}{l}\text { Ghola- } \\
\text { dan }\end{array}$ & $\begin{array}{l}\text { Huss- } \\
\text { aini }\end{array}$ & $\begin{array}{l}\text { Paki- } \\
\text { stan }\end{array}$ & India & USSR \\
\hline 1961 & $10,870.191$ & $37,266,958$ & 3.43 & 95.72 & 4.22 & .06 & - & 32.3 & 27.7 & 40.0 \\
\hline 1962 & $7,370,898$ & $56,121,522$ & 7.62 & 98.30 & - & 1.70 & - & - & 4.9 & 95.1 \\
\hline 1963 & $14,885,553$ & $119,071,384$ & 8.00 & 98.80 & 1.11 & .09 & - & $8: .9$ & 18.1 & - \\
\hline 1964 & $26,289,276$ & $246,137,355$ & 9.37 & 99.844 & .105 & .031 & .020 & 71.9 & 28.1 & - \\
\hline
\end{tabular}

Source: RGA Ministry of Commerce. Data obtained by A. Mobin 


\section{Destination \\ Percent of Yearly Exports}

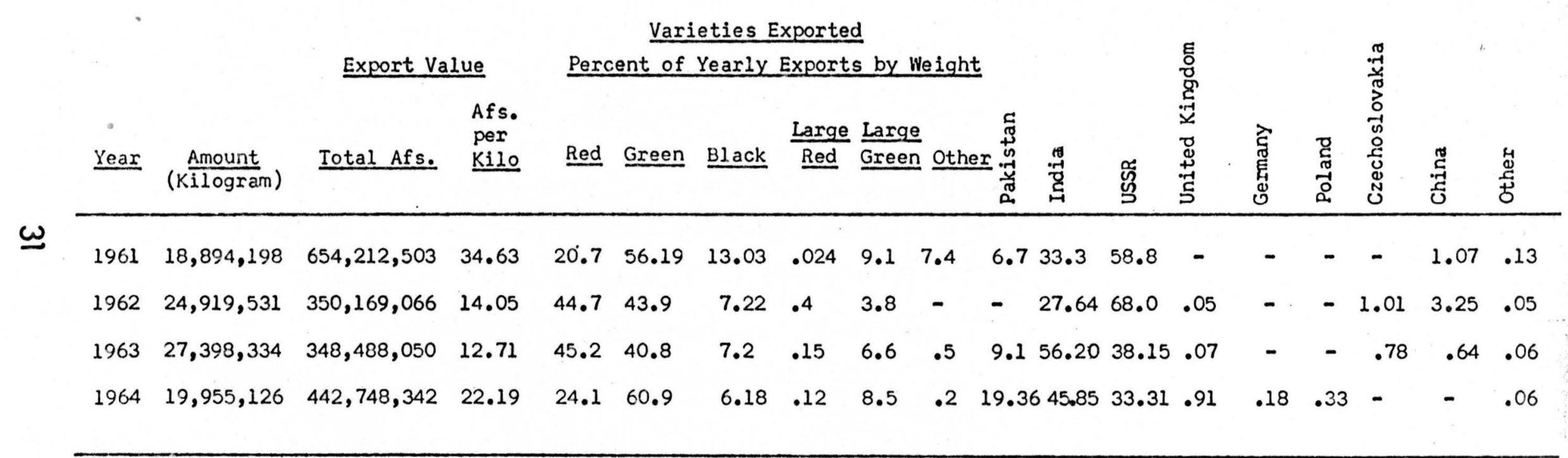


1. Contractors - contract for grape crop before harvest, take care of handling and transportation to Kabul where they sell through the wholesale fruit market.

2. Vineyard owners - sell their own grapes through the whole sale market.

3. Commission agents - sell grapes for growers, contractors, etc.on a commission basis.

4. Wholesaler - Retail sellers operate large retail outlets but also sell to other retailers.
The most popular variety in Afghanistan is Kishmishi, arelatively small white seedless grape. Five or six other varieties are also quite popular, and there is a total of more than 15 varieties sold at retail in Kabul.

Exports of fresh grapes are primarily to Pakistan, India and the USSR. Raisins are sold to these same cantries and to more distant nations suchas the United Kingdom, Poland, Czechoslovakia, Germany and China. Kishmishi is the most important variety for export as fresh fruit and as raisins.
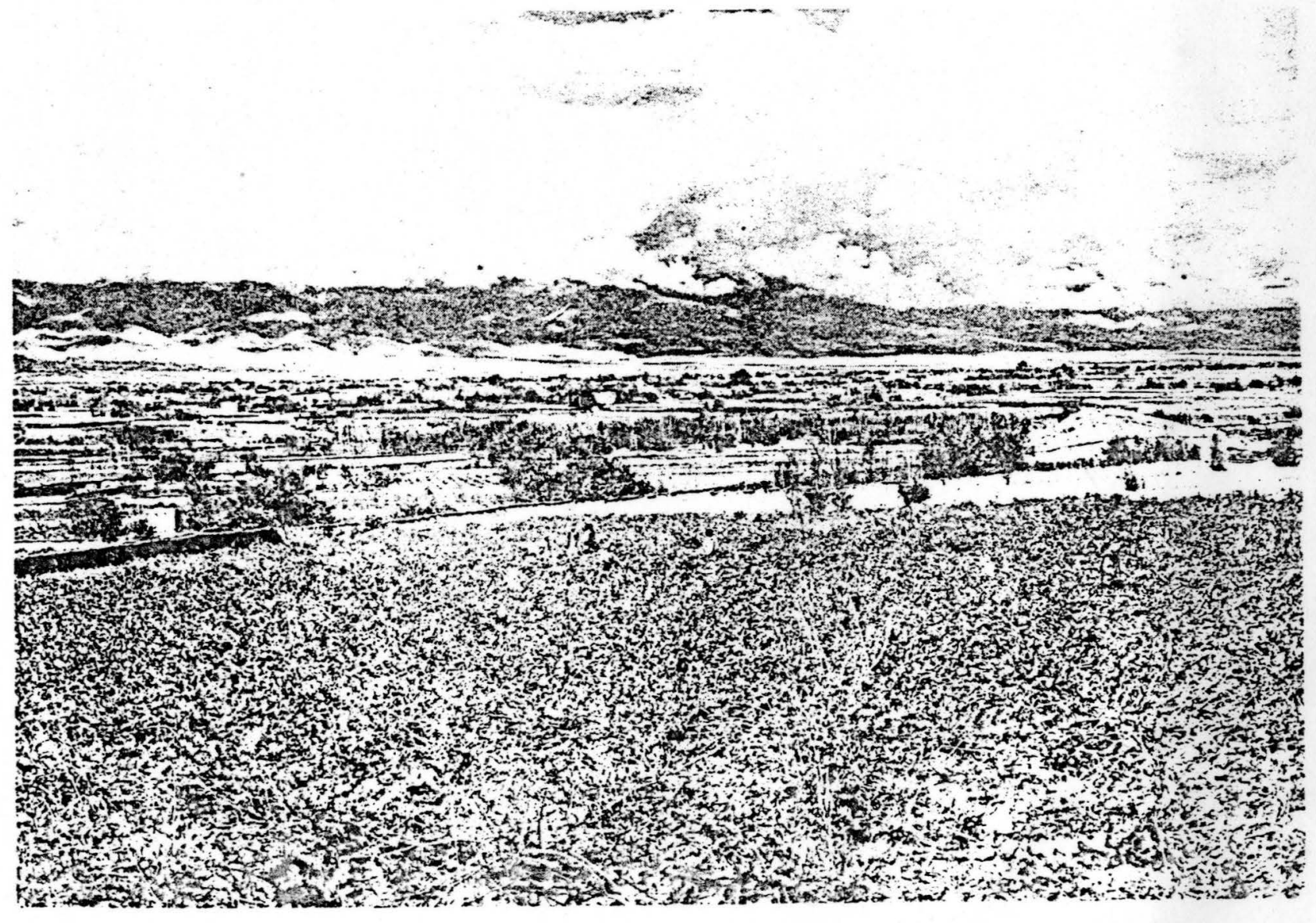

Large vineyard in the Koh Daman Valley. 


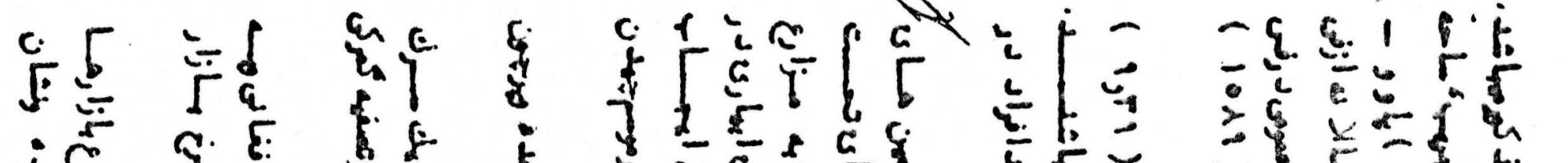

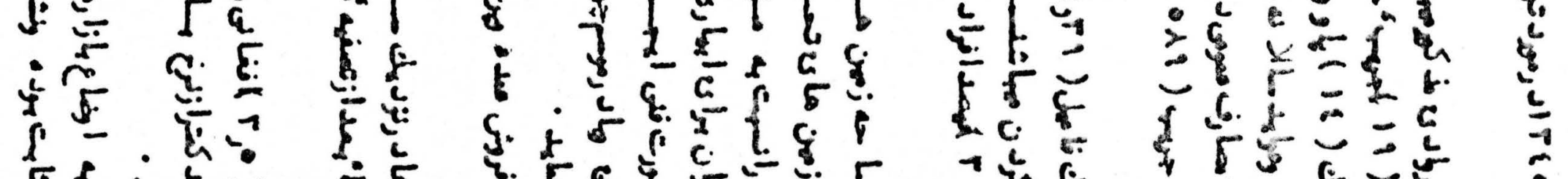

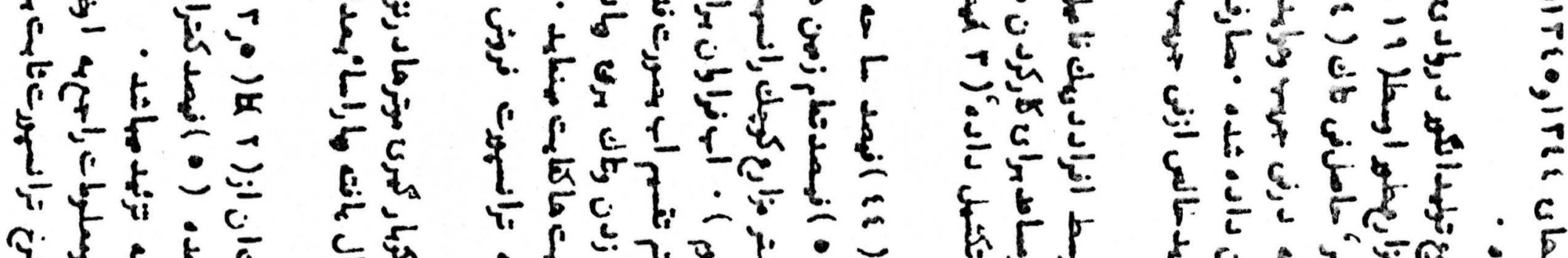

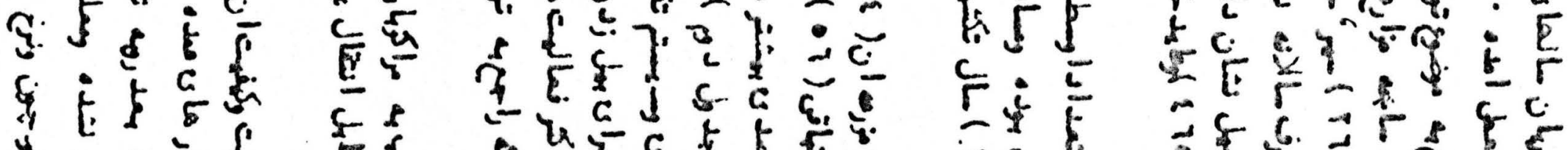

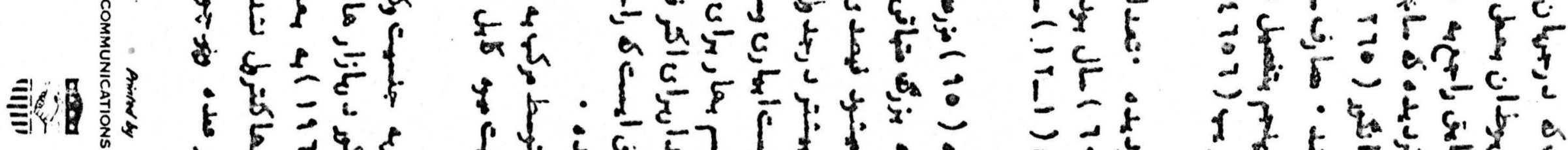

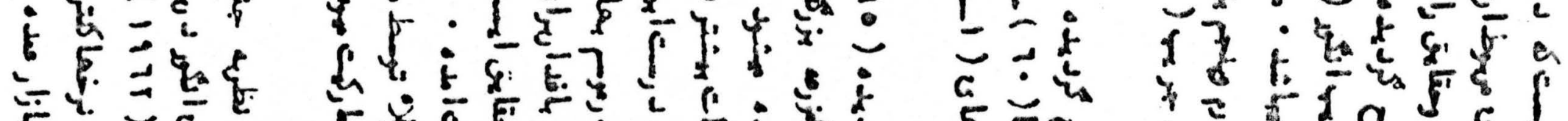

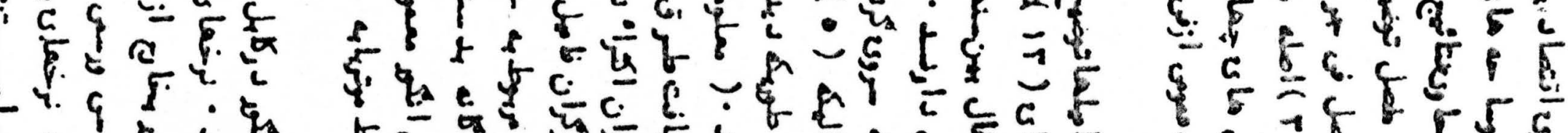

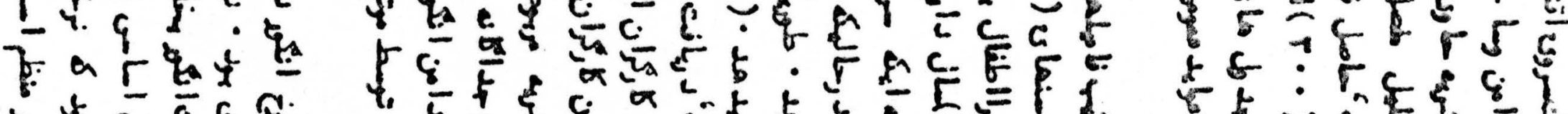

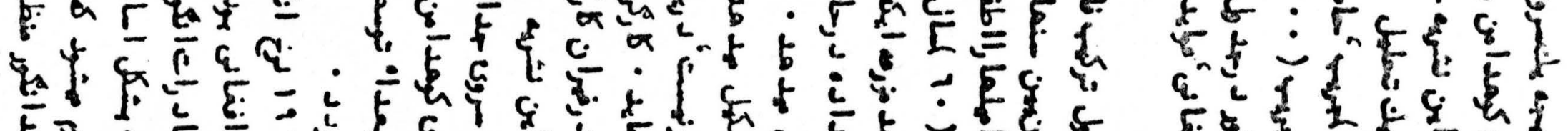
द. F.

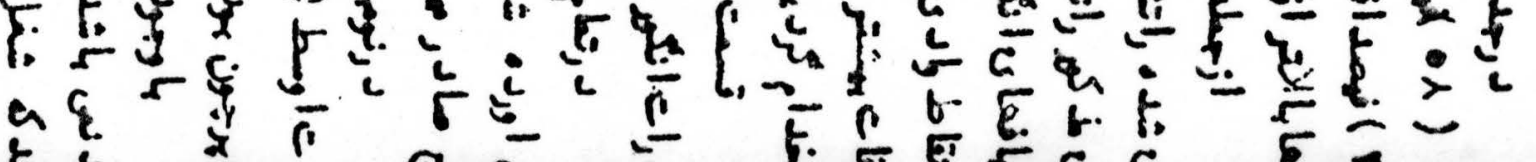

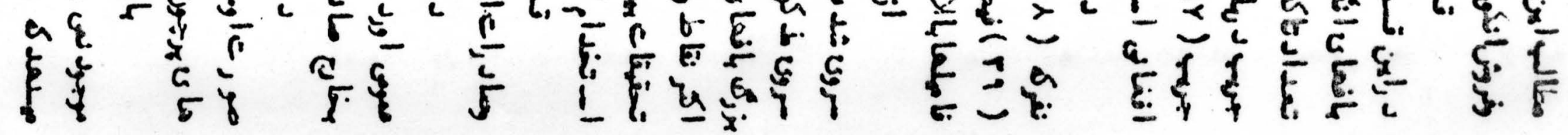




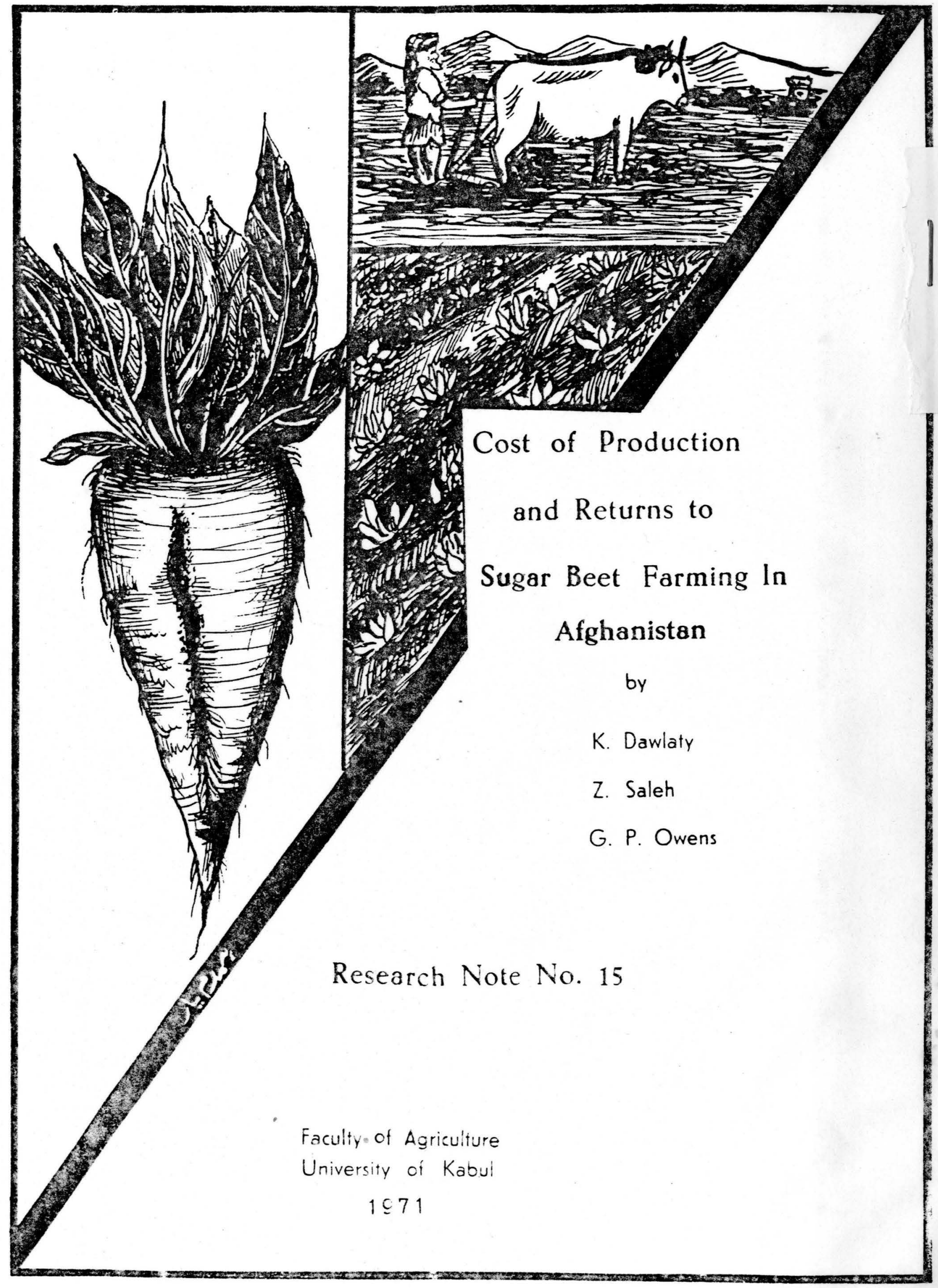


COSTS OF PRODUCTION AID RETURIS TO SUGAR BEET FARMING IN AFGHANISTAN (KUNDUZ AND BAGHLAN PROVINCES)

\title{
By
}

Khairuiah Dawlaty

Instructor of Agricultural Economics Faculty of Agriculture

Zarghuna Saleh

Research Assistant

\section{Gerald P. Owens}

Agriculture Economist the University of Wyoming Team

\author{
Research Note No. 15 \\ Faculty of Agriculture \\ Kabul University \\ Kabul, Afghanistan \\ August 1971
}




\section{ACKNOWLEDGMENT}

The authors wish to express appreciation to Dean llekozai and hssistant Dean Nawabi of the Faculty of Agriculture, Kabul University and the Wyoming Team for funding* the project and providing assistance and incouragment.

Sppreciation is expressed to the students of the Faculty of Agriculture who did the survey work. Mis. Abdul Rub Noori, Mr. Ghularn Jan, Mr. Jan Mohaurned, Mr. Abdul Monir and Juma Khan.

Thanks to the Bireators of Agriculture and the Extension personal in Kunduz and Baghlan for their help and guidance during the course of the survey work and to the farmers who provided the information related to costs and returns of cotton production.

*Special acknowledgrent to Nebraska Team for additional eopies of this technical bulletin (1976. 
COST OF PRODUCTION AND RETURN TO SUGAR BEET FABMING IN AFGHANISTAN

(KUNDUZ AND BAGHLAN AREAS)

By

Khairulah Dawlaty, Zarghuna Saleh

and G.P. Owens

\section{IMTRODUCTION:}

The najor importance of sugar beet production in Afghanistan lies in it's capacity to save Foreign Exchange. Sugar beet production is concentrated in Baghlan area of northern Afghanistan where the Baghlan Sugar Factory has been in operation since 1320 (1941). Annual production of sugar beet delivered to the factory has varied from 22,200 tons in 1321 (1942) to 67000 tons in 1346 (1967). Annual production of sugar has considerably increased during the 1340 (1961). This increase in domestic production in the face of rising demand for sugar (reflected in the annual imports) represents a considerable amount of saving of Foreign Exchange. Table (1) shows available data on area cultivatec in sugar beet, production of sugar beet and sugar and the imports of sugar for the year 1338-1347 (1959-1968).

PROBLEMS:

Cost and returns data for major agricultural commodities are essential for planring and organizing productive resources at both micro and wacro levels. At the time this study was undertaken, no such data were available for sugar beet in Afghanistan. OEJECTIVES:

The over all objective of thds study were to determine cost and returns 


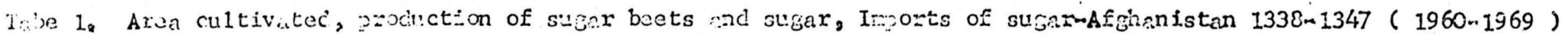

\begin{tabular}{|c|c|c|c|c|c|}
\hline$Y: ? \underline{E}$ & $\begin{array}{l}\text { aren Qultivated } \\
000 \text { recteras }\end{array}$ & $\begin{array}{l}\text { Production os Beets } \\
\text { 000 Metric Tons }\end{array}$ & $\begin{array}{l}\text { Production of Suger } \\
\text { 000 Meitric Tons }\end{array}$ & $\begin{array}{l}\text { Imports of susar } \\
000 \text { Metric ions }\end{array}$ & 000,000 Do1iars \\
\hline 1338 & 4,0 & 44 & 4.5 & 35.5 & 4.4 \\
\hline$\$ 339$ & 4.C & 44 & 4.5 & 30.2 & 3.6 \\
\hline 1340 & 4.0 & 44 & 4.5 & 41.0 & 5.0 \\
\hline 1341 & 3.6 & 61 & 8.0 & 30.0 & 3.6 \\
\hline 1342 & 3.6 & 56 & 7.1 & 10.6 & 2.4 \\
\hline 1343 & 3.5 & 31 & 3.9 & 35.9 & 5.7 \\
\hline 1344 & 4.0 & 56 & 7.4 & 25.3 & 3.0 \\
\hline 1345 & 4.0 & 56 & 7.1 & 70.0 & 6.4 \\
\hline 1346 & 4.5 & 67 & 7.5 & 57.0 & 5.3 \\
\hline 1347 & 4.5 & 62 & 5.3 & $\infty$ & - \\
\hline
\end{tabular}

30JRCa: Survey of Frogress, Ministry of P1enning, $1967 \cdot 1968$ and $1962-1964$ 
for sugar beots production in the Baghlan-Kunduz area of northern Afghanistin. ifore opociflocily the objectives were:

a. To determine labor requirements and labor costs per jerib* for sugar beet.

1. Fanily labor

2. Hired labor

b. To determine other inputs and costs per jerib for sugar beet.

1. Land-value and taxation

2. Power-work animels

3. Equipments

4. Seed

5. Fertilizer and chericals

c. To determine production, sales, gross and net returns per jerib for sugar beet.

\section{WETHODOLOGY:}

The data up on which this atudy is based were collected by direct interview with the famers in late 134.6 (1967). A pretested written field. schedule dealing with sugar beet and cotton production were adninistred by five trained Senior students of the Faculty of Agriculture under the direct supervision of the first author. With the assistance of the Directors of Agriculture and Extension personal in Baghlan and Kunduz a sanple of 130 farmers who grew sugar beet or, cotton and sugar beet were located and .

*1 Jerib $=.1936$ Hectare $=.4784$ Acres 


\section{$-4-$}

interviewed. After tabulation, data were available for 73 sugar beet enterprises. Data on cotton were analysed and published as the Faculty of Agriculture Research Note Nunber 12. Upward biases in reporting the expenses and dowmward biases in reporting the information related to the returns on sugar beets were felt in many instances during the interview. These biases were corrected or adjusted in the field or during the checking and editing of the schedules before tabulation of the data.

\section{RESULTS:}

The average size of the 73 sugar beet farms was about 20 jeribs in which about 4 jeribs were planted sugar beet and the rest were in other crops. The average sugar beet production per jerib was 3.40 tons per jerib. A]l of the beets produced were sold to the Baghlan Sugar Factory by contract. The expenses per jeribs of sugar beet production is displayed in Table (2) in four catagories. They are:

1. Labor expenses

2. Cost of materials

3. Depreciation of working capital

4. Miscellaneous costs

Sugar beet requires 44 man-days of labor per jerib for various operations listed in Table (3). About 50\% of the labor time is usec? in the operam ticns of weeding-cultivating and harvesting. The plowing-planting catagory is the next high labor using operation, The seed is planted in late Warch and Apxil, but ruch of it is grown in seedbeds for the first two or thrce ronths before it is transplanted. Following the plowing-planting, catagory transporting, application of the animal nanure and irrigation are the major 
labor using operations each raquiring about 6 man-days of labor. Tre: ty ni:e man-days of labor (66\% per jerib) is provided by the famers femily vinile is nan-days are supplied by hired labor at an average voge rate of 42.67 Afghanies per day including one neal. (Tablo (2).

Cost of materials per jerib was estimated to be 255.83 Afghanies. Secd and cherificals were provided by the Sugar Factory. Depreciation of worling capital (Iivestock and equipnents) were computed through straight lino method. An annual depreciation per head of Ilvestock was coi:puted by dividing the difference between the present value and the estirutod salvage value of a particular type of aniral into its expected useable life. The result was Fultiplicd by the average number of that particular type of livestock kept on Earn and divided by number of jeribs on farns to obtain the cost of livestock depreciation per jerib. The sarie procedure vas used to compute the clopreciation of equipnents por jerib. Due to linitation of tine the estinato for tho exponses of livestock feed was not possible, however, an estimate of 150 Afghanies per jerib bécame available later in the study of wheat faming in AfGhanistan by the same authors.

Thu Iast catagory of costs were the repair of Karize and Canal, tar on Iand, interest paie on borrowed capital, hauling and transporting of tho bots, and interest on capital investrent (value of the land). The total of this catagory was 756.4 Afghanies per jerib. All of the expenses are catagorizei into two groups (Table 3):

1. Out of pocket expenses

2. Other expenses

The firgt catagory includes ail of "those expenses for which the farmars 
Table 2. Exponses per Jerib for Growing Sugar Beets 73 Farmers Surveyed in Baghlan and Kuncuz Provinces 1346 (1967)

Expense Catagories

Farrily Labor

Hired Labor

Sub Total
Unit/Jerib Cost/Unit Afs.

$$
\begin{aligned}
& 29.29 \text { Days } \\
& 14.75 \text { Days } \\
& 44.04
\end{aligned}
$$
is.

$$
\begin{aligned}
& 42.67 \\
& 42.67
\end{aligned}
$$

1244.68

$\frac{634.50}{879.18}$

2. Cost of Material/Jerib

$\begin{array}{lccc}\text { Seed } & 0.86 \text { Seer* } & 0 & 0 \\ \text { Conmercial Fertilizer } & 2.19 & 27.27 & 59.73 \\ \text { Nianure } & 112.67 \text { Load } & 1.76 & 198.34 \\ \text { Chewicals } & 0.20 \text { Seer } & 0 & 0 \\ \text { Other } & & & -\frac{7.76}{265.83} \\ \text { Sub Total } & & & \end{array}$

3. Depreciation of Working

Capital/Jcrio

investod:

Horsod

Oxen

Donkeys

Camels

Equipient

Karachi

Wheelbarrow

Other

Sub Total

4. Hiscellaneous Costs/Jerib

Repair of Kariz \&e

Cana].

Taxas

Cost of Borrower Capital

Hauling \& Transport

Interest on Lane? Va?uo

Sub Total
2.50

16.57

0.80

0.12

4.55

0.22

10.76

35.5

Total 2936.91

$* 1$ Seor $=7.066 \mathrm{Kg}$. 
nust produce either the cash or credit on a yeariy basis and which are directly related to tho production process"*. The second catagory are indirect expenses and paynents to the family labor.

Feed for working livertock is not counted as a cash cxpense based on the assumption that livestock graze much of the year and the minimum feed anount given to then when they work, are grown on the farr. Cost of animal nanure is not included in Cash Expenses due to the assunpiion that there is no marketable cash value for anina? ianure, inspite of the fact that famers did report an imputed value of $(1.76)$ Afghanies per load of mariure for as average rate of (112) loads per jerib.

Interest on land value (609 Afs./jerib) and unpaid farily labor with the inputed value of $1249.80 \mathrm{Afs} / /$ jerib were not added to the cost iocause at the present stage of technology there are no better alternative usc for Iand and farily labor than the opportunity of enployment in agriculture**.

Tho total out of pocket expenses per jerib wore 880 lafrianies (nable 3 ). All tha sugar bects wore sold to the Baghlan Sugar Factory. Totai roturn (Table 4) with an averago yicld of 3.40 tons of sugar boets (priced at 576 Afgheres por ton inc?uding the velue of the buet tops at $23 \mathrm{hfs}$ ! were 1984.18 kf hanics per iorio. The returns to fanily labor arr managenent and investuent was 1104.03 Lfghanies per jerib.

\footnotetext{
*ithes: Furing in Afghanistan Cost of Production and Returas". K. Denlaty, Z. Seleh and G.P. Orens. Tochnicrl Bulletin IIo. 17 Facuity of hgriculture, Kabul University, Kabui, Afghwistar 1970. PP. 7 .

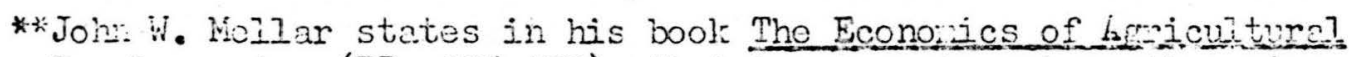
Doviopunt. (PP. 178-179), that in a country where there is a lac of existing alturnative opportunitios for use of ciner eapiticl or labor along with the famors inabilitics to urati such oprotunitius. The return to land is soldon groator ihar. 3\% and is froquantly loss than $1 \%$.
} 
Table 3. Out of pocket and other expenses per jerib of Sugar Beet (Afghanies) 73 Farms in Kunduz and Baghlan 1346 (1967)

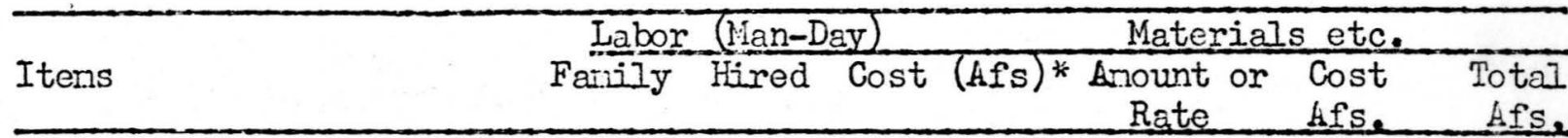

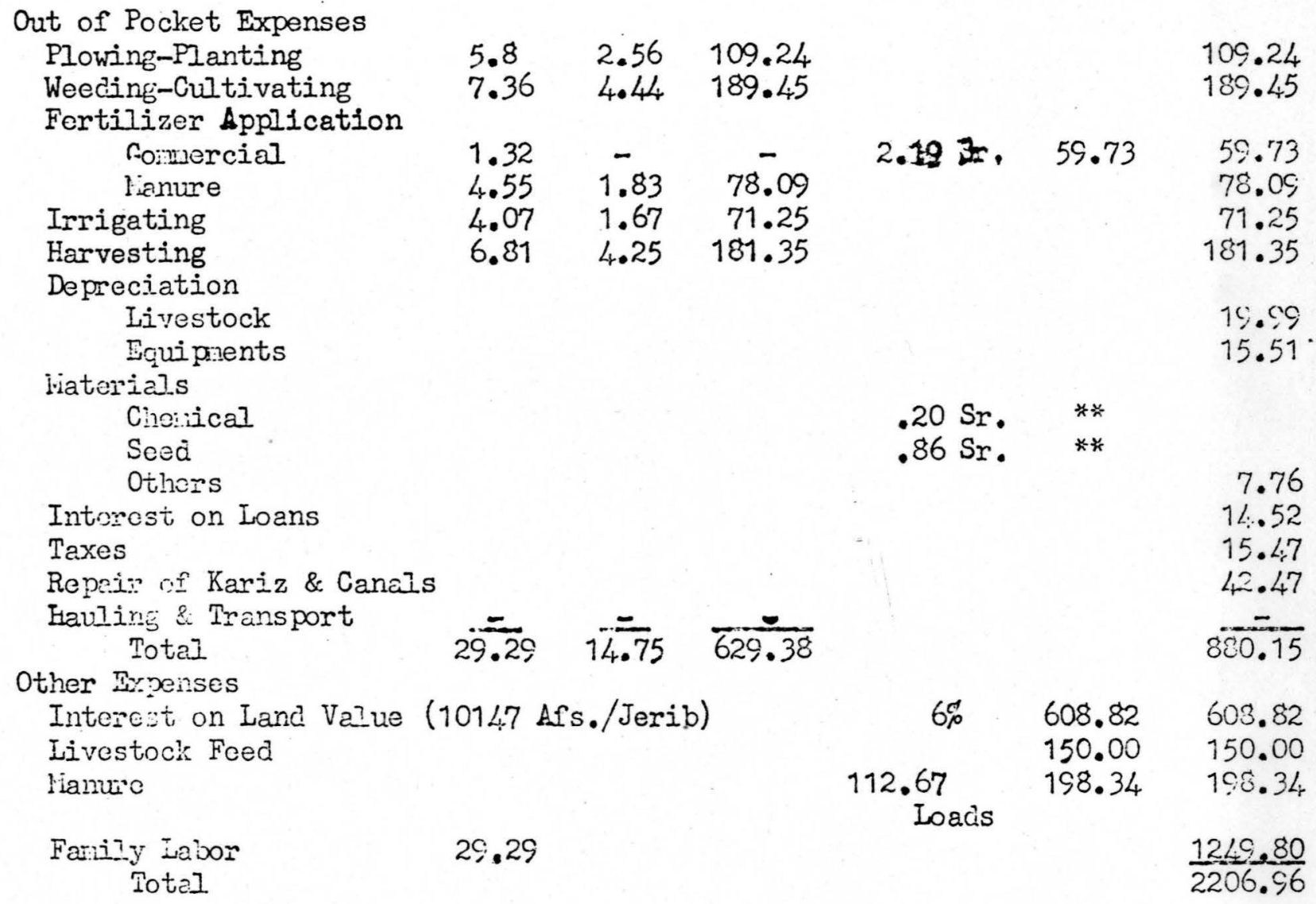

*Hirec Lator, 42.67 Afs./day

**Frovico? by Sugar Factory

Tablo 4. Returns per Jerib of Sugar Beet (Afghanies) 73 Farns in Kunduz and Baghlan 1346 (1967)

Itcis YleId/Jerib Price/Unit Total

Incove fre: Sugar Beet

Sucar Beet

Boet, Iops

576

1960.54

Tot:- Incone

3.4 Tons

$\frac{23.24}{1934.13}$

Los: out of Pocket Expenses

880.15

Ficturn to Investizent \& Fariily

1104.03

Labor 


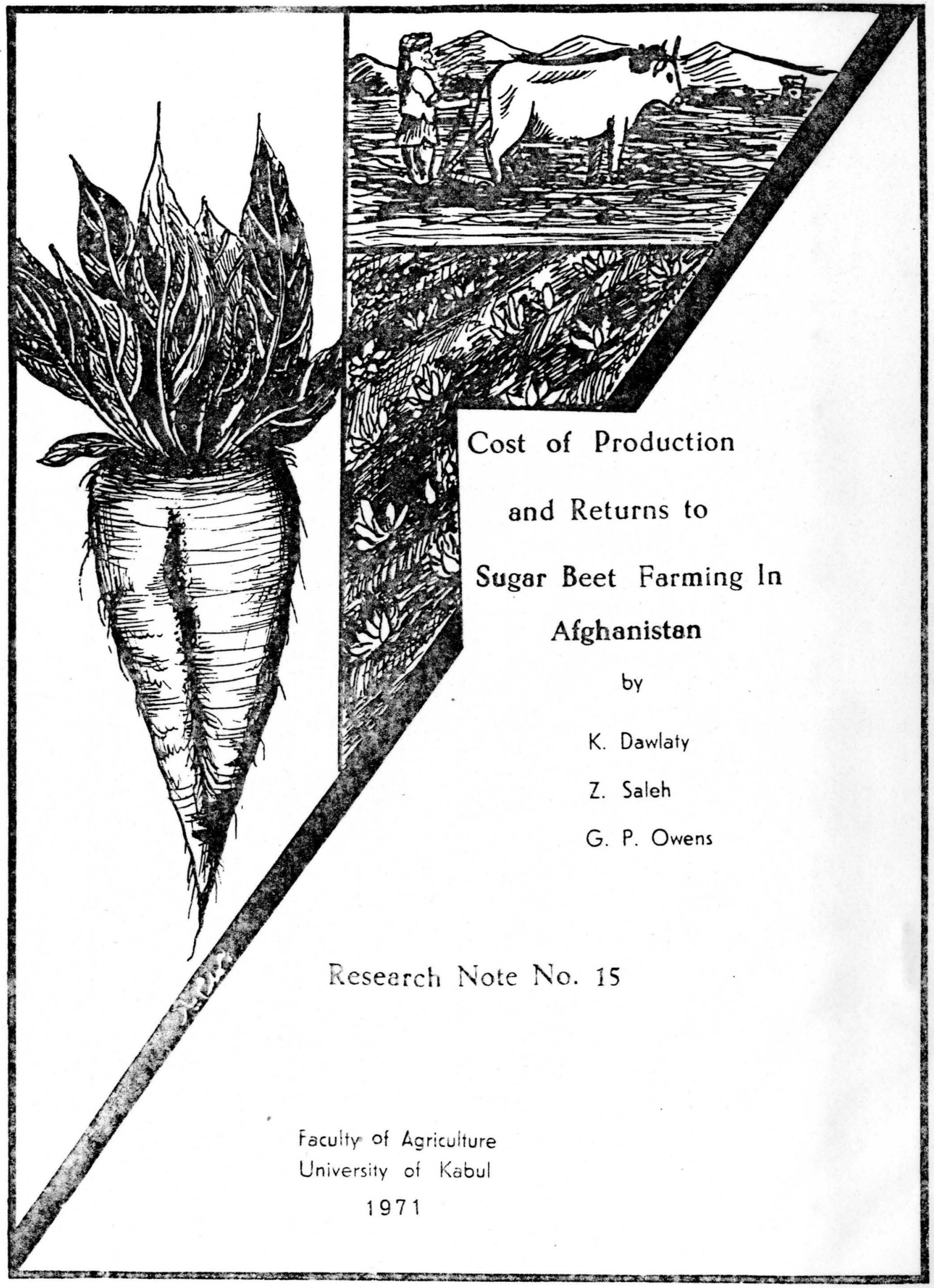


FARM TRACTORS AND WATER PUMPS IN AFGHINISTAN -

A STUDY OF UTILIZATION, ECONOMIC EFFICIENCY, TECHNICAL ASPECTS AND PROBLEMS OF AC UISITION AND OVINERSHIP.

by

Khai rullah Daw! aty

Richores Sounders

G:rald Owens

Technic:! Bullotin No. is

Faculty of Agriculture, Kabul University

Derember 1.369 


\section{ACKNOWLEDGEMENTS}

The authors gratefully acknow ige assistanc: and encouragment from the following people:

1) Dr. Horst Von Oppendfeld, IBRD Agriculture Credit Mission, for suggesting the study be conducted.

2) Dr. Af:al and Mr. Rahami, Prasident and Vice Prosident of the Agricultur: Bank, resp:ctively, for sponsoring the study and granting permission to publisin the findings from tine stisdy.

3) Dean Shah M. Alekczai of the Faculty of Agriculture for permitting staff to cooperate in conducting the study

1) Provincial Governors, Directors of Agriculture and Personncl in the Branch offices of tine Agricultur? Bank for assistanc? in carrying out field work.

5) Mr. Lewis Clark, A.I.D. Agriculture Credit Advisor, HAVA, and his Afghan associates for conducting field work in the $\mathrm{He}$ Imand-Kandahar area.

6) The farmers of Afghanistan who own tractors and pumps for providing information for this survey.

7) Professor Art Fabricius, Agricultural Enginear, Wyoming Team for tecinnical assistance in evaluating tractors and pumps from the engineering and performance standpoint.

3) The Study Coordinating Committee made up of representatives of the Ministri s of Agriculture and Irrigation, Financ:, Planning and this Agriculture Bank for encouragement and advice in planning the study. 
SIJMMARY OF KEY FINDINGS

TRACTORS

PIJMPS

INTRODUCTION

BACKROIND AND SITUATION

OBJECTIVES

PROCEDURES

LIMITATIONS OF STUDY

DEFINITION OF TERMS

TRACTORS

UTILIZATION

COSTS

OWNERSHIP COSTS

OPERATING COSTS

EFFECTS OF TRACTORS

ON AREA CIJLTIVATED ANNUALLY

ON CROP PRODUCTION AND YIELDS

ON SALES OF FARM PRODUCTS

ON FARM LABOR FORCE

ON ANIMAL POWER

FARMERS ' ATTITUDES, OPINIONS, AND PROBLEMS

PROBLEMS OF TRACTOR OWNERSHIP

ADVANTAGES OF TRACTORS 


\section{TABLE OF CONTENTS}

(CONTINUED)

ECONOMICS OF TRACTORS

COSTS AND BENEFITS

SUMMARY AND CONCLUSIONS

WATER PUMPS

UTILIZATION

COSTS

EFFECTS OF PIJMPS

OH: AREA CULTIVATED ANNUALLY

ON CROP PRODUCTION AND YIELDS

ON SALES OF FARM PRODUCTS

ON FARM LABOR FORCE

FARMERS ' ATTITUDES, OPINIONS AND PROBLEMS

PROBLEMS OF PUMP OWNERSHIP

ADVANTAGES OF MOTOR PIJMPS

ECONOMICS OF MOTOR PUMPS

COSTS AND BENEFITS

SUMMARY AND CONCLIJSIONS

APPENDI\%

UUESTIONNAIRES 


\section{LIST OF TABLES}

$\underline{\text { Table }}$

I THE DISTRIBIJTION OF BANK FIHANCED TRACTORS AND VATER PIIIPS IN AFGHANISTAN

II TRACTOR IJTILIVATION, 13:7 - MONTHS USED, HOURS ISER, AND AVER/IGE HOURS PER MONTH, HOURS PER DAY DURING BUSY SEASON AND DAYS IDLE PER YEAR, BY RIEGION

III TRACTOR UTILI, ATION, 13:7 - AVERAGE DAYS OF USE PER YEAR BY VARIOUS OPERATIONS

IV RATES FOR CUSTOM UORK -- AFS PER HOUR FOR PLOWING, CULTIVATION, DISCING, BY REGION

V TIME REQUIREI FOR VARIOUS TRACTOR ORERATIONS (HOURS) PER JERIB

VI TRACTOR IITILI:ATION, 13:7-- AVERAGE DAYS OF USE, BY SEASON

VII TRACTOR OPERATION BY SEASON - P PRCENT OVER$A L L$

VIII TYPES OF CROPS ON VHICH TRACTORS WERE USED - NUMBER OF JERIBS AND PERCENT OF USAGE BY AREA OF VARIOUS CROPS.

IX AVERAGE NUMBER OF FIELDS AND AVERAGE SITE IN JERIBS OF LARGEST AND SMALLEST FIELD ON W'HICH TRACTORS WERE USED

$\because$ TRACTOR IMPLEMENT UTILIZATION IMPLEMENTS OWNED, MOST USED, AND LEAST USED, BY REGION AND IN OVER-ALL STTUDY

XI TRACTOR DEPRECIATION SCHEDULES BY REGION -TRACTOR OUNERS: EYPECTATION OF USEFUL LIFE AND SALVAGE VALIJE

XII COSTS OF DPERATION - TRACTORS

XIII: CHANGES IN LAND USE BEFORE AND AFTER TRACTOR PIJRCHASE -- AVERAGE JERIBS PER FARM REPORTING

XIV DISTRIBUTION OF TOTAL JERIBS PLANTED AND TOTAL JERIBS IN FARM BEFORE TRACTOR PURCHASE AND IN I $3^{\prime}: ?$

$\because V$, FARH CROP PRODUCTION - PERCENT CHANGES IN YIELD AND CROPPING PATTERNS BEFORE AND AFTER TRACTOR PURCHASE ON FARMS OF TRACTOR OWNERS IN AFGHANISTAN 
XVI FARM CROP PROOIJCTION -. PERCENT CHANGES IN YIELD AND CROPPING PATTERNS BEFORE AND AFTER TRACTOR PURCHDSE ONA FARMS OF TRACTOR ONNERS IH NORTHERIY AFGHANISTAN

XVII FARM CROP PRODIICTION - - PERCENT CHANGES IN YIELD AND CROPPIING PATTERNS BEFORE AND AFTER TRACTOR PIJRCHASE ON FARMS OF TRACTOR OWNERS IN CENTRAL LIFGHANISTAN

ZVII FARM CROP PRODUCTION -- PERCENT CHANGES IN YIELD AND CROPPING PATTERNS BEFORE AND AFTER TRACTOR PIJRCHASE ON FARMS OF TRACTOR OWNERS IN SOUTHERN AFGHANISTAN

XIX SALES OF AGRICULTURAL COMMODITIES BEFORE AND AFTER TRACTOR PURCHASE, AVERAGE SALES IN SEERS PER FARM, NUMBER OF FARMS REPORTING, SALES, PERCENT OF CHANGE BY CROP, AND WHETHER OR NOT CHANGE WAS ATTRIBUTED TO TRACTOR OWNERSHIP

XX SALES OF AGRICULTURAL COMMODITIES BEFORE AND AFTER TRACTOR PURCHASE, AVERAGE SALES IN SEERS PER FARM, NUMBER OF FARMS REPORTING, SALES, PEREENT CHANGE BY CROP AND WHETHER OR NOT CHANGE LAS ATTRIBIJTED TO TRACTOR OWNERSHIP

XXI SALES OF AGRICULTURAL COMMODITIES BEFORE AND AFTER TRACTOR PURCHASE, AVERAGE SALES IN SEERS PER FARM, NUMBER OF FARMS REPORTING, SALES, PERCEHT CHANGE BY CROP, AND WHETHER OR NOT CHANGE WAS ATTRIBUTED TO TRACTOR OWNERSHIP

XXII SALES OF AGRICIJLTURAL COMMODITIES BEFORE AND AFTER TRACTOR PURCHASE, AVERAGE SALES IN SEERS PER FARM, HUMBER OF FIRMS REPORTING, SALES, PERCENT CHANGE BY CROP, AND WHETHER OR NOT CHANGE WAS ATTRIBUTED TO TRACTOR OWNERSHIP

XOII LABOR AND ANIHAL POUER RE UIREMENTS BEFORE AND AFTER TRACTOR PIJRCHASE - TOTALS, AVERAGES, AND PERCENT CHANGES FOR TENANTS; LABORERS, AND BULLOCKS

XYIV COSTS AND RETURNS FROM TRACTOR OWNERSHIP 
$\therefore X V$ NUMBER AND TYPES OF ITER PUM S IN STUDY

XXVI WATER PIJMP OPERATION - - DAYS OPERATED PER YEAR AND HOURS PER DAY BY SEASON, BY TYPE OF PUMP

XXVII JERIBS OF VARIOUS CROPS IRRIGATED BY WATER PIJMP $(13: 7)$

KXVIII COSTS OF OPERATION -. PUMPS

XXIX FARM CROP PRODIJTION - - TOTAL IREA PLANTED, PRODIJCTION, AND YIELD, BEFORE PUMP PURCHASE AND IN :3:\%

K火火 SALES OF AGRICULTURAL PRONUCTS BEFORE AND AFTER PIJMP PIJRCHASE - - AVERMGE SALES PER FARM, NUMBER OF FARMS REPORTING SALES, PERCENT CHANGE AND WHETHER OR NOT CHANGE WAS DUE TO PIJMP OWNERSHIP

XXXI: TOTAL JERIBS IRRIGATED, TOTAL JERIBS DRYLAND, TOTAL JERIBS PLANTED, AND TOTAL JERIBS

FALLOWED ON FARMS OF 27 WATER PUMP OWNERS

KXXII LABOR AND ANIMAL POWER REEUIREMENTS ON

FARMS OF WATER PUIMP OWINERS

XXXIII COSTS AND RETURNS FROM PIJMP OWNERSHIP

XXXIV LAND USE DISTRIBUTTION -- FARMS OF WATER PUMP OWNERS 


\section{SUMMIARY OF KEY FIHDINGS}

\section{Tractors}

Average tractor use is relative'y high in Afghanistan, as compared to U.S. A. standards, especially in the central area. Plowing is t'ie most important use for tractors. They are also used a graat dea, for hauling and privats transportation and are sometimes used in :ieu of oxen in grain threshing operations.

Returns from tractor use on dry:and crops were low.

Depreciation, operating costs and maintenance are higher than normal for the U. S. A. Operators expectations as to useful life seem to be overly optimistic.

In the early stages of partial mechanization covered by this study, tractor usage resulted in large increases in area cultivated, in total production and in sales of agricultural products. Tractors did not replace labor significantly, but caused a significant silift in tenancy and hired labor patterns. Deqan tenants (who furnished little more than 'abor in the terancy arrangements) gained at the expense of ejaradar tenants (who furnish oxen, sejd, etc. as well as laborl. Also, hired labor gained slightly over tenants. Tractors replaced anima! power very significantly.

Benefits from tractor use (value of additiona! production plus savings on oxen and income from custom work iss tota! tractor costs l were about 6 , ni? afs per year for all tractors. Benefits wer? highest in northern Afghanistan $(115,97$ per yarar) 
ower in soutbern Afghanistan $(.95,12,1)$ and negotive in central

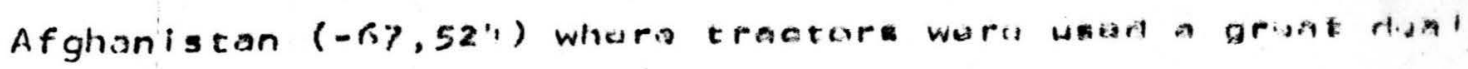
on extensive farms (dryland wheat).

Pumps

Pumps in centra: Afgianistan are used about thres montins of the year for suppl inental irrigation. Some tave bean used on newiy rac!aimed land and ar: tise primary source of irrigation. water. Pumps are used primarily to irrigate wheat and alfalfa and clover are the next most important crops.

Pump owners wer:a able to increase their cropland mors than 2 nn percent but there was evidence that tiney overextended themselves because yieids declined.

Net percentage increasis in sales were extremely high, but this is misleading because many pump owners began to sell farm produce only after they obtainet the pumps.

Pump use resulte: in significant incroases in farm labor and tonants. Animal power requirements also increased, but slight Iy I is than labor requirements.

Benefits to pump ownership basud on net jacreases in production less adiditional costs were nugative, on tee average. The following data are a summery of major findings:

\section{TRACTORS}

\section{Utilization}

Hours used per month

Percent of use for plowing

Percent of use for hauling

Percent of use on Irrigated Wheat

Parcent of use on Dryland liheat
Overal! Avarag: .132 
Origina! cost of Byolarus tractors (afs)

Original cost of Mass yy-Furguson tractors (afs)

Estimated usefu! I ife (years)

Annual depreciation - Byelarus: (afa)

Annual depreciation - Massey-Ferguson (afs)

Annual operating costs - Byclarus: (afs)

Annual operating costs - Massey-t zrguson (ofs)

Rates for custom work (afs per hour)

Effects of Tractors on Production

Overa: Averag:

Percent change in area cultivated annually $\therefore$

136

Percent change in annual output of major crops:

Irrigated Wheat
Dryland Wheat
Barley
Corn
Cotton
Oilseeds

Effects of Tractors on Siales:

Percent change in Crop Sales:

theat (irrigated and dryland)

Corn

Cotton

C:over and alfalfa

0 ilseeds

Neion and watermelon

Mung B.:ans

Effects of Tractors on Farm Labor Forc:

Percent chang? in number of:

Total farm workers

Degan (buzgar) tenants

Fuil-time hired labor 2 rs

Effects on Annual Power Requirements

Percent change in number of bul locks

Benefits

Value of additional output per farm per year (afs)

Savings on oxen maintenance and degree per farm/year (afs $k 2.3,3 ! 1$

Total benefit perfarm per year (afs)

Less total tractor costs perfarm per year (afs)

Net benefit per farm per y:ar (afs)

$+162,863$

$+115,165$

if, 99

T) Keshtegar (Pashto) - a tennant who provides his awn labor and other inputs such as oxen, implements, fertilizer in the tenure arrangement.

2) baxgar (Pashto)- a tennant who provides his own abor and little or nothing alse in the tenure arrangement. 


\section{WATER PUIAPS}

Utilization

Overal: Average

Doys operatel annuaily

Percent use on:

whent

Alfalfa and Clover

Corn and Barley

Melons

Oth:r crops (including vegetables)

$\underline{\operatorname{Cos} t s}$

Original cost of:

B.aco (Pakistan) $2 n$ HP (afs)
B.co iphkistan) $7 \frac{1}{3}$ HP (afs)
Soviet i:HP (afs)

33,255

$5,5: 1$

Annual operating costs:

$$
\begin{array}{r}
1:-2 \mathrm{HP} \\
13-16 \mathrm{HP} \\
7-10 \mathrm{HP}
\end{array}
$$

Effects of Pumps on Proriuction

Percent change: in area cultivated annually
Percent chang: in annual output of major crops:

$+256$

frrigat wheat

Dryland lineat

Alfalfa and Clover

Melons

Corn an: Barley

Vegutab! ?s

Other Legumes

Other Crops

$+2: 3$

$-33$

$+2 n 3$

tingr

$+3 \div 5$

$++20$

$+2.33$

+3 n

\section{Effects of Pumps on Saies}

Percent change in annual crop sales:

Wheat (irrigated and dryland) $26 n$ n

Corn

Vegetables

$+3 ; \div$

Mrions

0 ilse zis

$+9 n 1$

Tobacco

$+297^{\circ}$

$+127$

Alfolfa and Clover

Other Legume Crops 
Percent change in number of:

Total farm workers

Deqan tenants

Full-time hired laborers

Part-time hired laborers

+ $2 ! 11$

$+5: 6$

$+66$

$+229$

Effect on Annual Power Requir memts

Percent change in numbsr of bullocks

\section{Benefits}

Value of additional output per farm per year (afs) $5 !, 2$ !n Less total pump costs per farm per year (afs) , ,3,5.39 Net loss per farm per year $\quad-32,379$ 
Farm Tractors and Water Pumps in Afginanistan -

A Study of Utilization Economic Efficiency, Technical

Aspects and Problems of Acquisition and Ownership

by K. Dawlaty, R. Saunciers and G. Owens*

\section{INTRODUCTIONE}

Backround sind Situation

Beginning about 1963 , the Agriculture and Cottage Industries Bank of Afghanistan, hereafter referred to as the Bank, imported Byelarus and Massey-Ferguson tractors and four types of water pumps. These tractors and pumps were sold on credit to farmars in various parts of Afghanistan. Most of the Byelarus tractors were sold in northern Afghanistan; most of the MasseyFerguson tractors were sold in cantral and southern areas. Water pump sales were concentrated in the Ghàni; Katawa:, Mogor and Kalat area of central Afghanistan. Table I shows the distribution of Bank-finances tractors and pumps by province.

Although a iarge number of water pumps have been imported privateiy, most of the privately owned farm tractors in tiis country have been imported under the auspices of the Bank.

Recently, tine Bank coased operations in tinis fild, but is currently negociating a loan from the kor!d Bank (IBRD) which will allow it to rasume oparations. T is study was undertaken in hopes of improving future Bank operations in the field of financing agricultural zquipment.

*K. Dawlaty is assistant profossor (pohanmai) of Agricultural Economics at the Faculty of Agriculture, Kabul University. [r. Saunders is an Agricultural Economist with the Robert Nathan Associates USAID Contract Team - advisors to the Binistry of Planning. Dr. Owens is Agricultural Economics advisor to the Facutty of Agriculture, Kabul University; employs by the USAID/ liyoming Tizarn Contract. 


$$
\text { Tabl: } 1
$$

The Distribution of Bank-Financed

Tractors and Water Pumps in Afghanistan

Location

Province

Kabul

Logar

Paktia

Ghazni

Orozgan

Zabul

Kandahar

Helmand

Chakhansur

Farah

Ghor

Herat

Faryab

Jows jan

Wardak

Balkh

Samangan :

Kundu?

Bagh! an

Parwan

Takhar

Kapisa

Laghman

Nangarinar

Ministry of Agr.

Nangarilar Project

Sugar Factory

- Cash Sales E Oth.
Tractors

Beleyrus Massey-Ferquson

2

$-$

2

$-$

$-$

$-$

$-$

-

-

$-$

$\overline{7}$

7

$-$

32

13

2.2

!1

1

!

$\frac{15}{22}$

11

$\frac{\begin{array}{c}2 \\ +2 \\ 2 n !\end{array}}{?}$

2

2

2.

i

.

35

7

21

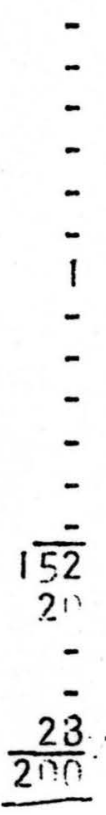

Wiatur Pumps

$20 H P \quad 16$ HP $7 \frac{1}{2} H P$

6

7
1
69

37

37
-5

(1)

-

$$
\text { ( }
$$

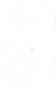$$
\text { (- }
$$

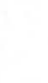$$
\text { ( }
$$$$
\text { (2) }
$$

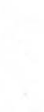$$
1
$$$$
\begin{array}{ccc}
- & 2 & 3 \\
- & - & - \\
-1 & - & - \\
\frac{1}{15} & \div & \overline{6 !} \\
- & - & - \\
- & - & - \\
135 & - & -
\end{array}
$$ 
Some bad debts were accrued in previous operations. Also, conditions of future ne.d and demand for tractors and pumps are unclear. This is aiso true for efficiency and economic performance of tractors and pumps in Afghanistan. More information on the relationship between mechanization and unemployment is needed. Information regarding the effect of tractors and pumps on land reclamation and development is also nesded.

Obiectives

The broad objective of this study is to shed as much light on tie above stated problems as possible. More specifically:

A. To investigate conditions of nesd and demand for tractors and pumps by geographical area if possible.

B. To examine the current uses of tractors and pumps.

C. To examine the effects of tractor and pump ownership on employment and land use.

D. To investigate problems associated with cbtaining tractors and pumps and problems associated with ownership and operation.

\section{Procedures}

The primary tool for gathering information for this stuty was personal interviews with tractor and pump owners using a schedule pretested with tractor and pump owners near Kabul. Related data and information from other sources were used whenever possible. Twenty-eight tractor owners were personaliy interviewed by author Dawlaty in the northern anci central areas. Professor Dawlaty also persona!ly interviewed 2" pump 
owners who had a total of 4 , pumps in the central area. These interviews were conducted in Apri! and May, 136\%. Mr. Lewis Ciark, Agriculturai Credit Specialist, USAID Lashkar Gah, and associates interviewed $1 ?$ tractor winers in the soutinern area during this same period.

A list of all tractor and pump owners provided by the Bank was stratified geographically and randomly sampled. An' altarnate sample was drawn for use when owners selected in the stratified random sample were not available for interview. After enumeration, data were tabulated in raw form and then analyzed by various sorts and cross-tabulations to obtain the required descriptive data and relationships. Limitations of Study

The major limitation to this study results from size and stratification of sample. Aithough the universe was not large ( $\mathrm{nn}$ tractors and 265 water pumps' on!y $\because !$ tractors and 43 pumps were covered by survey information. This was due to the decision to make extensive intervi aws and to limitations of time and funds. On!y tirree major ar as (? provinces) were studied, leaving out tractor use in western Afghanistan

The study was designed, tabulated, analy ed and reported in English while enumeration was carried out in Farsi.

\section{Definition of Terms}

Ejaradar - Persian word for tenant classification; usually provides seud, machinery and animal powar as part of tenancy share arrangement.

Cashgar - Pashtu word equivalent of efaradar. 
Degan - Persian word for tenant classification; provides less than ejaradar tenants and recieves a smaller sinare of crops.

Buzgar - Pashtu equiva!ent of degan.

1 jerib $=.179 \%$ acres $=.1936$ hectares

1 seer $=15.53$ pounds $=7.066$ ki lograms

$13:$ (local year) $=$ March 21, 1953 to March 2r, 1969

Inn afs $=\$ 1.33$ U.S. (75 afs $7 \$ !$, n U. S.)

\section{TRACTORS}

\section{Utilization}

Tractors in this study range from six years of age to less than one year. Most of the tractors were purchased in $13: 5$ and $13: 5$ (rougin!y 1.665 and 1967).

Tractors in the noth had been used an average of about 17 months, those in the central area about 1 ! months and those in the soutin about $2^{n}$ montins. Average total hours used ranged from 1349 in the central area to $2: 3:$ in the south. Average hours per month were about 93 in the nortin, 1 ? in the centra! ar $\geq a$ and $2:$ in southern Afghanistan. This is relatively high usage compared to !J. S. standards. Daily use jluring the busy season averaged .36 hours in the central area, in, hours in the north and 12.2 in the south. Number of idle cays per year ranged from 11 , in the south to 13 in the central ar 23 , This information is shown in detall in Table 11.

Plowing was by far the most important use for tractors, as all 2 were used for this purpose. All tractors were uses" for hauling alsc, but they were not used as muci for this purpose. 
Tabie I1. Tractor Utili.ation. 13:7

Honths Used, Hours Useo, and Average Hours Per Month, Hours Par Day During Busy Sazson and Days I dle Per Year, By Region

\section{Months Used}

Aver. Range

Nortin

Central

Soutin

Overali
Total

Hours Usel Hours Per Month

Aver. Range Aver. Range

18811501.3260

$99.055 .6-166.7$

$1848 \quad 1026-2: 25$

$2434 \quad 1000-5500$

$2098,1000-5500$
Hours par Day Busy Season

Avir. Range

1n.6 $3-12$

$3.4 \quad 3-12$

$12.2 \quad 3-1.3$

$10.9 \quad 3-13$
Daye lail Pr Y Y

ver. Pince

$\because i-i s$

$\therefore \quad 12 r-2 \div$

$\therefore 6$

$14: 2$

$\therefore 0.2 !$ 
Table 111 shows the number of tractors used for the various operations and average number of days per year that the tractor was used for each operaticn. Number of tractors raporting for each operation is expressed as a fraction of all tractors in the area (or the overall study) - for example 1!!13 tractors means that i's of 13 tractors in the south were roportedly used for discing.

Many tractors were used indirectly in the pianting operation even though this is not reflected in Table $1 ! 1$. Many farmers pulled a mallah behind tice disc or field cultivator to cover up seed wilicin had been previously speead by hand.

Cultivating was reported as piowing in the northern and centrai areas because the implement there is known as a "chisel plow" and is generally used for stirring loose soil rather than cultivating growing crops. Use of the field cultivator or "chisel plow" is raported separately for the southern regions. (Field cilltivator or tilier was not provider with Byelarus tractors.!

Most thesining was don by driving the tractor over grain on a traditional thresining floor.

Considerable tractor work in the central araa was for land leveling, which indicates that considerabl: new land was brought into projuction or improved. Land leve! ing was negligible in the northern ar 3 a and was not don in the south (most tractors in the south wers on project land where leveling is done by the Helmani-Arginandab Valley Authority.). 
Table 111. Tractor Utilization, 13':"

Average Days of Use Per year by Various Operations

$$
\text { N* Plowing }
$$

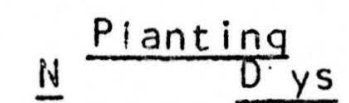

$\begin{array}{lll}\text { North } & 1: 11 ! & 73 . \\ \text { Central } & 12 / 12 & 7 \% .1\end{array}$

South ivilis 54.0

Overall :4/4 70.9

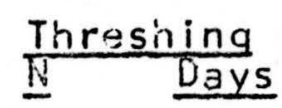

$\begin{array}{lcc}\text { North } & 9 / 1 \% & 16.6 \\ \text { Centra: } & \because / 12 & 7.3 \\ \text { South } & 1 \% / 13 & 3.3 \\ \text { Overal1 } & 31 / 4 \% & 11.9\end{array}$

$3 ! 1 \quad 7.5$

n

ก

$3 / \cdots$

$14614 \quad 52.3$

$12 / 12 \quad 27.7$

$13 / 19 \quad 27.6$

$4 / 133.4$

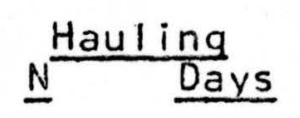

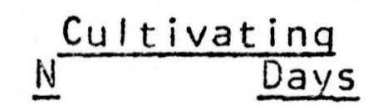

?

o

$37 . ?$

155

Custom Work

N Days

$7 / 1: \quad 13.0$

$6 / 12 \quad 15.7$

$5 / 13+.0$

$1 \therefore / 4$

190 $\frac{\text { Discing }}{\text { Dass }}$

$\because 1+\quad 25.3$

$\because 12 \quad 1$.

$1 \div 11 \quad 136$

$2: 14 \quad 13.4$

\section{$\frac{\text { Land Levz!ing }}{N}$}

$2 ! 1: \quad \therefore$.

$9612 \quad 3 \%$

ก.

$11 / 4 i+3$

*N Number of operators who reported any amount of tractor use for specifies operation expressed as a fraction of all tractors in region or in overall study. 
Less custom work was done in the south than in the other areas. Some operators said they woult do more custom work if parts were more readily available. See Table 1l! for details of tractor utili ation by operation. Table iV shows rates cbarged for custom work and Table $V$ shows average time required for various tractor operations.

Tractors are most used in the fall. Next most important season is summer, then spring. Tractors are used very little in the winter. Sae Tabie Vi.

Table 1V. Rates for Custom Work.

Afs Per Hour for Plowing, Cultivating, Discing, By Region

North

$$
\frac{\text { Piowing }}{15^{1}}
$$

$\frac{\text { Cultivating }}{1+i}$

$\frac{\text { Discing }}{1 \rightarrow 0}$

Central

15.3

153

153

Soutis

$2 n 6$

$2 n 5$

$2 n r$

Overall

17

$1 \% n$

$16 . ?$ 


\begin{tabular}{|c|c|c|c|c|c|c|c|c|}
\hline & NORTH & & CENTRAL & & SOUTH & & OVERSLL & \\
\hline & Aver. Hours & Range & Aver. Hours & Range & Aver. Hours & s Rng. & Avar. itrs. & Range \\
\hline Ist Plowir? & .67 & $.33-1$ & .63 & $.25-1$ & I. $n^{\prime}$ & $\cdot{ }^{n}-1.5 n$ &.$? !$ & \\
\hline ?ne Prowi.us & .61 & $.25-1$ & .33 & $.1 \cdots-.5$ & .79 & $.50-1 . r i$ & $.6 n$ & \\
\hline Disring & .35 & $.12-.75$ & .21 & $.1-.3 .3$ & .36 & $21-\ldots$ & .32 & \\
\hline Cuitivating & & & & . & .36 & $.25-.5 i$ & .35 & \\
\hline Cultiveting & - Wallah Comb & ination & & & $\therefore$ & $.17 . .8 \%$ & $\ldots$ & \\
\hline wisc-inallan & Cumbir ation & & & & .25 & & .25 & . \\
\hline Planting & & & & & $.1^{\circ}$ & & .19 & \\
\hline
\end{tabular}


Table VI. Tractor Utilizaticn, 13:7

Average Days of Use, By Season

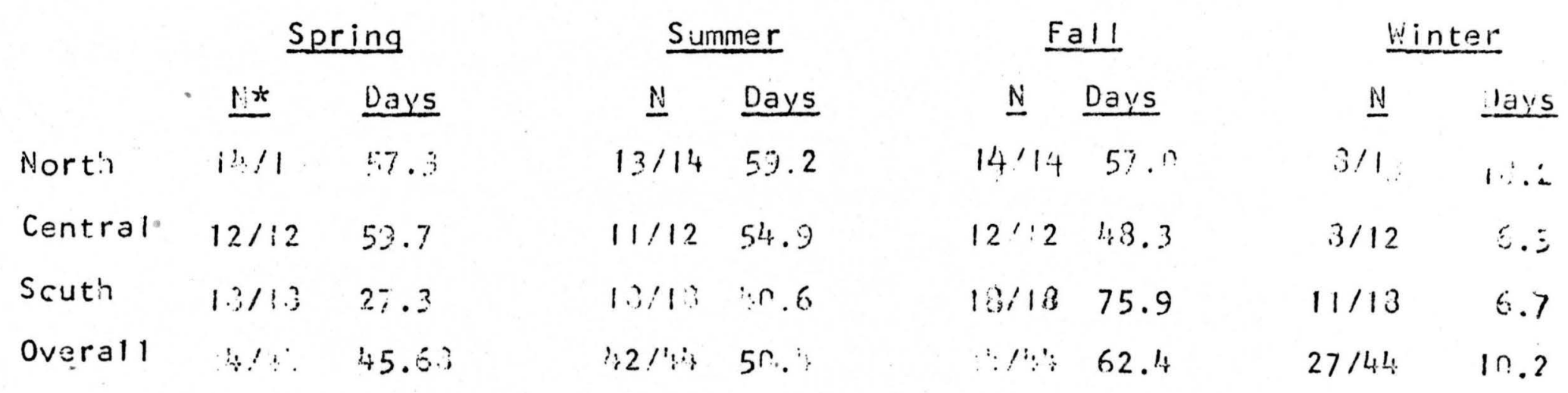

${ }^{*} N$ Number of operators who reported any amount of tracter use during specified season expressed as a fraction of all tractors in region or in overall study. 
Table V1I shows percent of total seasonal use for various operations and percent of total use for various operations during each season.

Table V111 shows tractor use for various crops by area and in the overall study. From the standpoint of number of jeribs on which tractor was used, wheat is by far the most important crop. Cotton, corn, alfalfa and clover are also quite significant. Dryland wheat is quite important in the central area, but not in the south.

Table IX shows average size of largest and smallest fields on which tractor is used. From this information, it would seem that small field size is not a major problem for tractor utilization in Afghanistan. It should be noted, huwever, that after these fields are prepared and planted by the tractor, they are usually ridged and/or ditched into very small plots for flood irrigations. This would affect tractor cultivating and harvesting operations. Also, the ridges and ditches must be smoothed out before the tractor can be used to prepare the soil for the next ceop. Many tractors in the central area are used on widely separated fields.

Implements provided as part of a "package deal" (inwhich the farmer had no choice) were, for the Byelarus tractor;

1. Three-furrowed moldboard plow

2. Disc Harrow

3. Four whe tractor-trailer

4. Front-mocnted scraper blade 
For the Massey-Fergusun 135:

1. Three furrow moldboard plow - MF 793

2. Tandrem Disc Harrow - MF 722

3. Nino-tine tiller (field cultivator or "chisel plow" MF 729

4. Three-ton tipping trailer MF 17-7

5. Multipurpose b1ade-terracer MF 721 
Table V11

page 10

Tractor Operation by Seasun, Percent Overall lo,

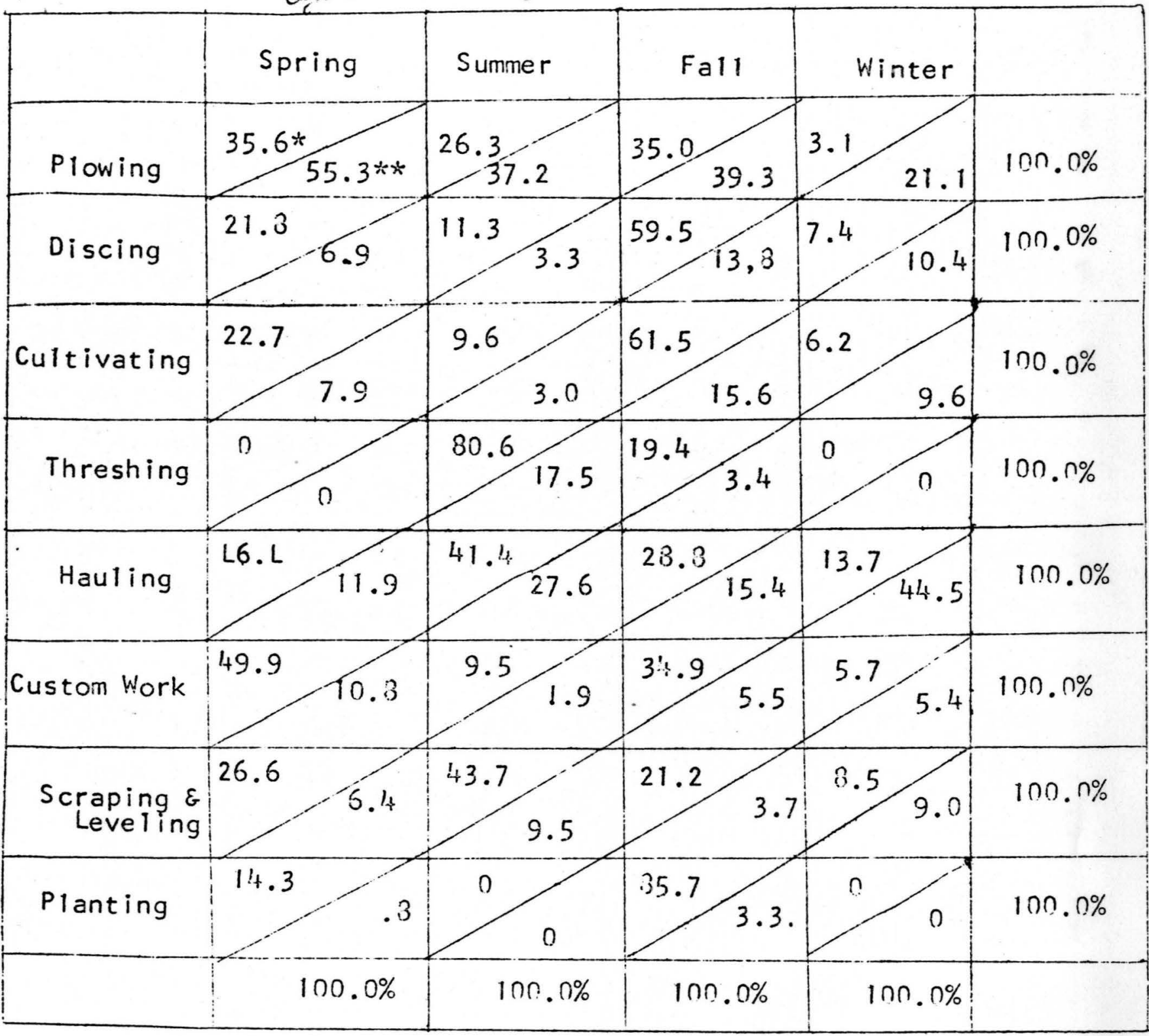

7,3

*35.6 percent of all plowing was done in the springtime **55.3 percent of all springtime tractor use was for plowing. 
Table Vill

Types of Crops on Which Tractors Were Used. Number of Jeribs and Percent

(1) of Usage by Area of Various Crops

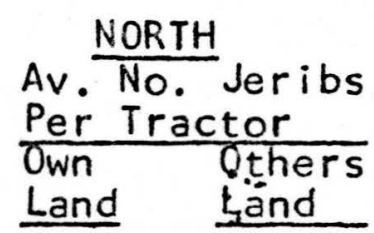

Irrigated Wheat

Dryland Wheat

Corn

Barley

Mung

Beans

Cotton

Clover \&

Alfalfa

011 seeds

Melons

Other

Total
(2)

CENTRAL

Percent Av. No. Jeribs of total

Per Tractor

Own - Others

Total

Tractor

$160.1 \quad 35.2$

Land

$102.3 \quad 35.8$

$77.4 \quad 17.0$

$230.7 \quad 300.7$

$15.4 \quad 3.4$

n

0

0

0

22.04 .3

1.7

)

1.7

'.2.

$5.7 \quad 1.3$

0

0

ก

Percent Total

Total Tract or 'te

$\begin{array}{rl}133.1 & 13.2 \\ & =\end{array}$

$539.0 \quad 70.9$

0

ก

0

0

$1.1 \quad .2$

40.6

1.3

1.9

5.5

15.: $\quad 3.4$

11.4

0

$11.7 \quad 1.5$

$\begin{array}{ll}5.9 & 1.3\end{array}$

7.0

7.0

.9

$34.4 \quad 13.6$

21.3

$21.3 \quad 2.3$

0

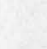




\section{Table VIII \\ (cont inued.)}

\section{SOUTH \\ Average No. \\ Jeribs Per \\ Tractor Land $\theta$ t

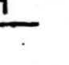

$3 ! \div 3.3$

32.9

0

0

41.8

0

0

0

14.3

0

0

4.9

0

17.3

0

460.3

\section{OVERALL}

Percent Average No, of Jaribs Per

Total Tractor Tractor Use

Land.

Aand

Total

Peresnt of total Tractor Use

\begin{tabular}{|c|c|}
\hline \multirow{2}{*}{\multicolumn{2}{|c|}{$\begin{array}{l}\text { Pereent } \\
\text { of tota } \\
\text { Tractor } \\
\text { Use } \\
\end{array}$}} \\
\hline & \\
\hline 244.7 & 43.7 \\
\hline 171.5 & 30.7 \\
\hline 22.0 & 3.9 \\
\hline 13.9 & 2.5 \\
\hline 3.9 & .7 \\
\hline 35.6 & 6.4 \\
\hline 14.7 & 2.6 \\
\hline 8.1 & 1.4 \\
\hline 5.3 & 1.0 \\
\hline 39.6 & 7.1 \\
\hline
\end{tabular}

$\begin{array}{llllll}17.3 & 3.4 & 13.7 & 20.9 & 39.6 & 7.1\end{array}$

$41.8 \quad 8.2 \quad 22.0$

0

3.90

10.4

25.2

.4

3.10

0

100.0 


\section{Table 1\%}

AVERAGE NUMBER OF FIELDS AND AVERAGE SIZE IN JERIBS OF LARGEST AND SMALLEST FIELD ON WHICH TRACTORS WERE USED

Number of Fields Largest Field Smallest Fieid All Fieids

$\begin{array}{lccrr}\text { North } & 7 & 295 & 9.4 & \\ \text { Central } & 12 & 276 & 23.0 & \\ \text { South } & -- & 136 & 8.8 & 46.8 \\ \text { Overall } & -- & 224.8 & 12.9 & \end{array}$

Table $X$ shows which of these implements were owned, most used and least used, by area. For the overall study, the plow was most used and the scraper, or blade, was least used. Very few implements not included in the package deal had been obtained by tractor owners. In the south, farmers indicated which additiona) implements they would like to buy. Of 17 responses (severa: tractor owners indicated more tinan one implement) fifteen wanted grain drills, fourteen wanted threshers and aight wanted a a ridger-ditcher attachment. Otiner impiements mentioned were: mower - 2, manure spreader - 2. cotton planter - 1, and feed grinder - 1. These responses, a! though not indicative of effective demand, do show which implements farmers feal the greatest nesd for in the south.

\section{Ownership Costs:}

Tractors were, sold with implements as follows:

Byelarus - $26,262,3$ afs

Massey-F arguson - - 363,353,9\% afs.

Terms were five years to repay at $6 \%$ intarast on unpaid balance. A $25 \%$ down-payment was required. Tota! cost of 
tractors and implements, including interest, was 300,039.17 afs for the Byelarus tractor and $4,3,65.65$ afs for the Mass ay-Farguson tractor. Tractor taxes were reported by som? owners to be as high as 15, nnn afs per year.

Table $\times i$ shows what operators expected in terms of usefu! life and salvage value and, consequently, depreciation (calculated by the straight-line method). According to the experience of Indamer Workshop in Kabul and Mr. Arden Fabricius, the Agricultural Engineer at the Faculty of Agriculture at Kabul University, these estimates are overly optimistic. Actual depreciation per year should be about 27 , nrin afs per year for th: Byalarus tractor and $42, n n n$ afs per year for the Massey-Ferguson, assuming about ten years of useful $1 \mathrm{ife}$ for the Byelarus and nine yaars for the Massey-Ferguson. These are raw estimates, based on information from Custs of Owning and Operating Farm Machinery by Greer, et ai.., University of Nebraska, U. S. A.

Operating Costs:

Operating costs for three regions are shown in Table 811 . Par hour fuel costs for the Byelarus tractor are almost 60 percent. higher than for the Massey-Ferguson and tine required for various operations does not seem to differ greatly between the Massey-Ferguson and Byelarus tractors.

Due to differences in enumaration technicues, the autiors believe that costs other than fue! and oil costs and wages were understated, especially in the north and central areas. The following total oparating costs are felt to be more in line with reality. 


$\begin{array}{lr}\text { North (Byelarus) } & 80,000 \text { afs per year } \\ \text { Central (M-F) } & 10 n, \text { non afs per year } \\ \text { South (M-F) } & 95, n n n \text { afs per year }\end{array}$

Table $\times 1$

TRACTOR DEPRECIATION SCHEDULES BY REGION

TRACTOR OWNERS" EXPECTATION OF USEFUL LIFE AND SALVAGE VALUE

NORTH

Make of Tractor

Byelarus

Original Cost pius

Interest $(5$ years $6 \%) 311,32 \%$

Useful Life

19

Salvage Velue

11,111

Depreciation/Near
CENTRAL

MF

35,247

32

4.3, non

$12,1 n 1$
SNUTH

MF

435,247

12

77,222

29,335

The reader should bear in mind that total costs are for differing yearly usage -- 11,0 hours per year in the north, 21.91 in tine central area and $15 \mathrm{mn}$ in the south.

Although the Massey-Ferguson tractos in the south were older than those in the central area, they were used more intensively and, thersfore, probably required about the same amount of repairs. Repairs include tires and batteries although nane of the owners had replaced rear tires.

Costs of fue! vary fram 2 ' afs per imperial gallon (16.7 afs per U.S. gailon), to afs per litre (15.1' afs per U, S. gation). In addition, irreguarities involving extra costs in obtaining fuel and parts were reportet. For fuel, these could not have been very bad, however, because our computation of fuel consumption 
Table $\times$

TFACTOR IMPLEMENT UTILIZATION IMPLEMENTS OWNED MOST USED AND LEAST USED STUPY REGION AND IN OVERALL

\begin{tabular}{|c|c|c|c|c|c|c|c|c|c|c|c|c|c|}
\hline & & ORTH & & & & ENTRAL & & & SOU & & & & OYERALL \\
\hline I & $\begin{array}{l}\text { Most } \\
\text { Used }\end{array}$ & $\begin{array}{l}\text { Least } \\
\text { Used }\end{array}$ & $\begin{array}{l}\text { Pever } \\
\text { Used }\end{array}$ & Owned & $\begin{array}{l}\text { Most } \\
\text { Used }\end{array}$ & $\begin{array}{l}\text { Least } \\
\text { Used }\end{array}$ & $\begin{array}{l}\text { Never } \\
\text { Used }\end{array}$ & Owned. Most & $\begin{array}{l}\text { Least } \\
\text { Used }\end{array}$ & $\begin{array}{l}\text { Tever } \\
\text { Used }\end{array}$ & Jwined & $\begin{array}{l}\text { Mcst } \\
\text { Ljed }\end{array}$ & $\begin{array}{l}\text { Last luc } \\
\text { Jad Us }\end{array}$ \\
\hline
\end{tabular}

\begin{tabular}{|c|c|c|c|c|c|c|c|c|c|c|c|c|c|c|c|c|}
\hline Plow & 14 & 10 & -- & -- & 12 & 3 & 1 & -- & 13 & 17 & 0 & -- & 34 & $3 c$ & 1 & -- \\
\hline Disc & 14 & 1 & 2 & -- & 12 & 1 & 7 & 4 & 13 & 10 & 6 & $\cdots$ & $1+4$ & 12 & 15 & 4 \\
\hline $\begin{array}{l}\text { Field } \\
\text { Cultivator* }\end{array}$ & 2 & -- & -- & -- & 11 & 7 & -- & -- & 18 & 8 & -- & -- & 31 & 15 & -- & $\cdots$ \\
\hline Trailer & 14 & 4 & $-\because$ & -- & 12 & $\begin{array}{l}1 \\
i\end{array}$ & -- & -- & 13 & 2 & 4 & -- & $i s s_{t}$ & 5 & 3 & - \\
\hline Scraper & 14 & 7 & $\cdots$ & - & 12 & 3 & 1 & -- & 13 & 2 & 3 & -- & 44 & 5 & 10 & - \\
\hline Seeder & 1 & -- & -- & 1 & 1 & -- & 1 & -- & -- & -- & - & -- & $<$ & -- & $!$ & 1 \\
\hline Harvestek & -- & -- & -- & & 1 & $-\infty$ & 1 & $-\infty$ & $-\infty$ & -- & -- & -- & 1 & -- & 1 & $-\infty$ \\
\hline Pulley & 1 & -- & -- & 1 & 2 & -- & -- & 1 & -- & $-\infty$ & $\cdots$ & -- & $\because$ & -- & -- & 2. \\
\hline
\end{tabular}

*In the north and central, used for plowing. 
shows about $1.14 \mathrm{U}$. S. gallons per hour consumption for Massey-Ferguson tractors. The Nebraska Tractor Test Data book for 1969 reports that this type of tractor should use 1.4 U. S. gallons per hour with "average load".

Table $\times 11$

COSTS OF OPERATION $=-$ TRACTORS

\begin{tabular}{|c|c|c|c|c|c|c|}
\hline $\begin{array}{l}\text { Afs } \\
\text { Hour } \\
\end{array}$ & $\begin{array}{l}\text { ORTH } \\
\text { Afs I } \\
\text { Year } \\
\end{array}$ & Total & $\begin{array}{r}\text { CENTR/ } \\
\text { Afs Afs } \\
\text { Hour Year } \\
\end{array}$ & $\begin{array}{l}\text { L } \\
\text { Total }\end{array}$ & $\begin{array}{l}\text { SOUTH } \\
\text { Afs Afs } \\
\text { Hour Year } \\
\end{array}$ & Total \\
\hline $\begin{array}{l}27.0 \\
31.2 \\
13.6\end{array}$ & & 32,076 & $\begin{array}{l}17.2 \\
20.0 \\
11.6\end{array}$ & 37,685 & $\begin{array}{l}17.0 \\
13.6 \\
13.7\end{array}$ & 25,500 \\
\hline
\end{tabular}

$0 i 1$

Grease

Transmission

Lubrication

Filters

Air Ceeaner

oil

Diese 1

Wages

Driver

Cleaner

Repairs

Total Operating

Costs
$4,3894,839$

508

503
$6,1026,102$

$4,1044,104$

569

569
1.783

2,289

3,133

7,210

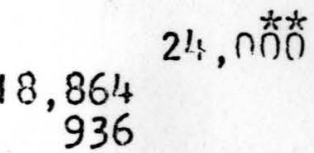

12,852
2,268

$13,500^{13,996 * *}$

27,906

7,344

$\underline{3.092}$

64,637

71.444

92,365

*Total Fuel Costs are obtained as follcws:

$([($ afs hr plowing $\times 2) \quad(a f s$ hr hauling $\times 1)]+3) \begin{gathered}\text { (average hours } \\ \text { per year) }\end{gathered}$

**Total wages includes 2 inn afs per year for foct, clothing and hcusing fur drivers and cleaners. Most operators did not emplo; cleaners. 
Indamer Workshop in Kabul provided standard prices for oridinary maintenance ttems. From notes on intervisw schedules, we found that some centra! and southern tractor owners are obtaining some of these items cheaper from other sources, particuiarly Pakistan. Ehis is not intended as a criticism of liorkshop policy and prices because our study does not include this phase of tractors in Afghanistan, and actual costs reported by owners are not high, on the average.

It is felt that most categories of costs of operation, especially in the north: and central areas, are under-reported. Rough calculations indicate that costs per hour including depreciation are the afghani equivalent of about $\$ 1.4 n$ in the south. This compares with costs of over $\$ 2.50$ in the U.S. A. for this type of tractor.

"Down-Time" or the amount of time a tractor is inoperable awaiting repairs, is somerinat high.

Wages for tractor drivers are an expense not normaliy encountered in the U.S. and other countries, as the farm fami:y usual!y does this. Hages for driver and driver's helper (cleaner) amount to about $2 n, 000$ afs per year -- roughly one-fourth of total costs. However, from notes on the questionnairs, this seems to be money well spent und ar current conditions. In more than one instance, inexperiencz's drivers certainiy do not get the highest and best use of their macinines. Most tractor owners wer: able to employ experiences drivers with some difficulty, but these drivers commanded a fairly high wage -- usually 2 , nnn afs per month. 
As mentioned previously, taxes are an unknown, but possibly very significant, cost factor.

\section{Effects of Tractors:}

An attempt was made to measure changes in land use, crop production, sales of agricultural products, and labnr and animal power. Terms of reference for the change were "before tractor was purchased" (which was, generally speaking, three years prior to enumeration or $13 \%$ ) and "13:7" -. the crop year immediately preceeding enumeration. Respondents were also asked to indicate if these changes (when change took place) was or was not due to tractor ownership. On Area Cultivated Annualiy:

Table XIll shows overall lant use before tractor and in 13:7. A brief interpretation of this table reveals that tractors were responsible fur an increase in farm size, number of jeribs planted, and ieribs irrigated. Largest increases were in ronted land and there was a decrease in ..owned jeribs of dryland. This indicates that some owned acreage was brought under water command as a resu!t of tractor ownersinip.

Table Klll shows changes in land use by area and Table KIV is a distribution of jeribs planted and farm size.

\section{On Crep Production and Yields:}

Tab!e XV shows percent changes in area planted, pruduction, and yield of various crops. Wien change was attributer to tractor ownership, area and production of all crops increased. Yield also increased for al! crops except mung beans and chick-p:as, clover and alfalfa, and oilseeds. 
Wheat is by far the most important crop in Afghanistan and aiso the only crop for which fairly reliable production data is available for the entire country. Wheat production actually did increase for the entire country by about 30 percent from 1344 to 1347 and much of this increase was from dryland acreage. According to Table XV, wheat production increased 98 percent for irrigated and 1423 percent for dryland on farms which attributed change to tractor ownership. (See Price and Crop Outlook for Afghanistan - August 1968 and September 1967 - available at USAID/Agriculture Division) This increase was attributed to favorable weather and higher prices.

As will be discussed later, the overall production increases cauld be valued at about 133,000 afs, almost half of which was sold.

(On Sales of Farm Products:)

Table XIX shows average sales in seers per farm and percent for the overall study. The average value of increased sales per farm is about 55,000 afs. Sales of all agricultural commodities (on farms that attributed change to tractor ownership) increased except in the case of fruits. In addition to increases in sales, more farms reported any sales during 1347 than before tractor was purchased. Tables XX, $X X I$, and $X X \mid 1$ show sales by area. 
Tab!e $\times 111$

CHANGES IN LAND USE BEFORE AND AFTER TRACTOR PURCHASE AVERAGE JERIBS PER FARM REPORTING

\begin{tabular}{|c|c|c|c|c|c|c|}
\hline & & $\frac{h a n g e}{Y}$ & 5 dwe to & $\frac{\text { OVERALL }}{\text { Tracto }}$ & $\frac{\text { Ownersh }}{N 0}$ & hip \\
\hline & fore & $13+7$ & $\% \Delta$ & Before & $1 \longdiv { 3 1 7 }$ & $\% \triangle$ \\
\hline $\begin{array}{c}\text { Jeribs Irrigated } \\
\text { Owned } \\
\text { Rented }\end{array}$ & $\begin{array}{r}315 \\
0\end{array}$ & $\begin{array}{r}606 \\
15\end{array}$ & +92 & $\begin{array}{r}1007 \\
315\end{array}$ & $\begin{array}{r}1050 \\
291\end{array}$ & $\begin{array}{r}+4 \\
-3\end{array}$ \\
\hline $\begin{array}{c}\text { Jeribs Dry'and } \\
\text { Ownet } \\
\text { Rented }\end{array}$ & $\begin{array}{r}770 \\
32\end{array}$ & $\begin{array}{l}354 \\
653\end{array}$ & $\begin{array}{r}-54 \\
+1941\end{array}$ & $\begin{array}{r}336 \\
0\end{array}$ & $\begin{array}{r}175 \\
0\end{array}$ & $\begin{array}{r}-48 \\
--\end{array}$ \\
\hline $\begin{array}{c}\text { Jeribs Planted } \\
\text { Owned } \\
\text { Rented }\end{array}$ & $\begin{array}{r}354 \\
32\end{array}$ & $\begin{array}{l}547 \\
553\end{array}$ & $\begin{array}{r}-55 \\
+1644\end{array}$ & $\begin{array}{r}286 \\
0\end{array}$ & $\begin{array}{r}443 \\
50\end{array}$ & +59 \\
\hline $\begin{array}{c}\text { Jeribs Faillowed } \\
\text { Owne:t } \\
\text { Rented }\end{array}$ & $\begin{array}{r}230 \\
20\end{array}$ & $\begin{array}{l}319 \\
20\end{array}$ & $\begin{array}{r}+39 \\
0\end{array}$ & $\begin{array}{r}1253 \\
35\end{array}$ & $\begin{array}{r}1270 \\
90\end{array}$ & $\begin{array}{r}+1 \\
+157\end{array}$ \\
\hline
\end{tabular}


TABLE XIII CHANGES IN LAND USE BEFORE AND AFTER TRACTOR PURCHASE AVERAGE JERIBS PER FARM REPORTING

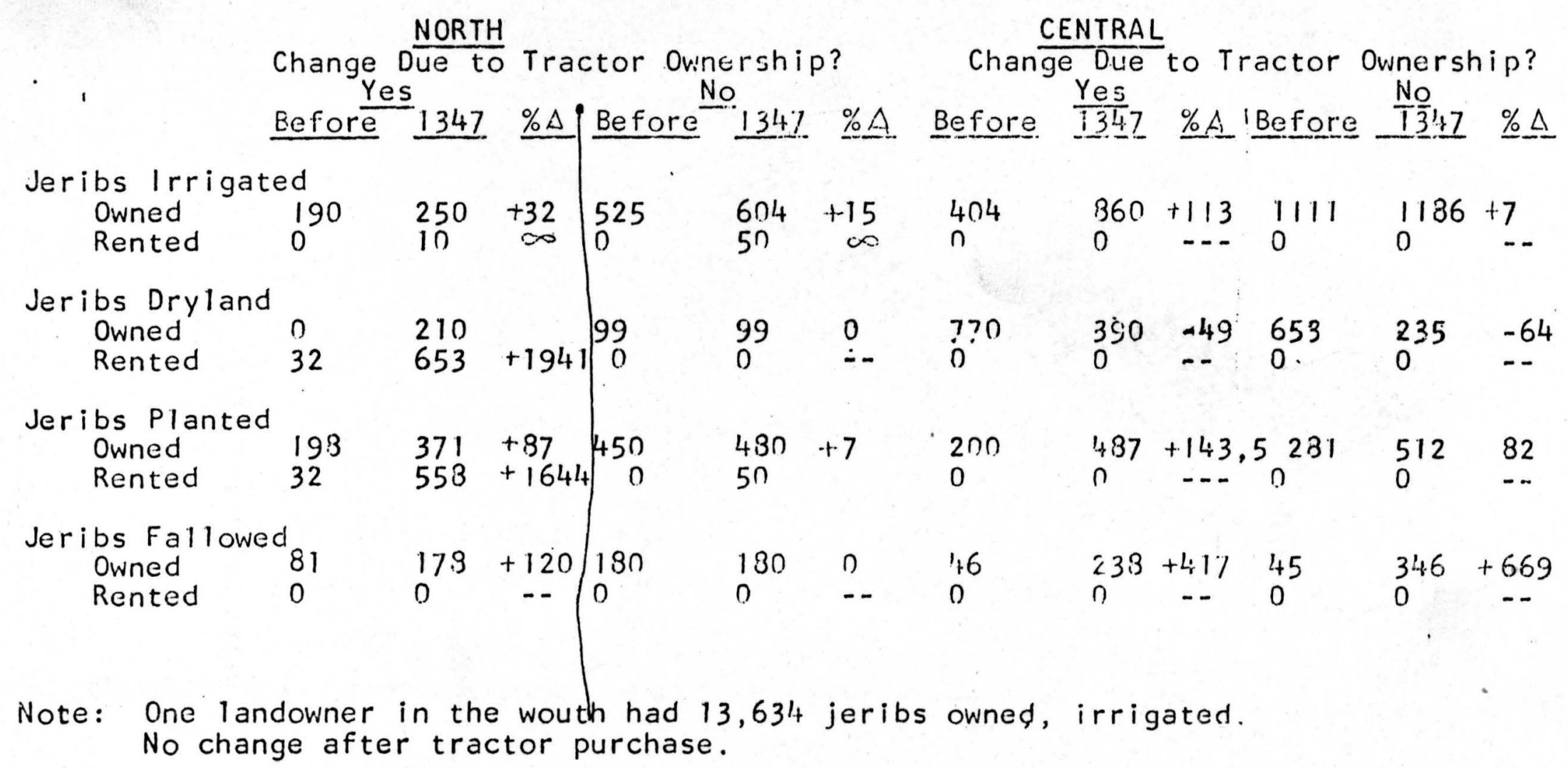




\section{Table XIII \\ (Cont inued)}

SOUTH

Change Due to Tractor Ownership?

Before $\frac{1347}{13 \Delta}$, Before $\frac{N 1}{1347} \% \Delta$

Jeribs Irrigated

Owned

$R: \geq n t e d$

$\begin{array}{lllllll}0 & 0 & - & 1213 & 1213 & 0\end{array}$

$\begin{array}{lllll}0 & 20 & \infty & 315 & 332+5\end{array}$

Jeribs Dryland

Owned

Rented

$\begin{array}{llllll}0 & 0 & - & 0 & 0 & - \\ 0 & 0 & - & 0 & 0 & -\end{array}$

Jeribs Planted

Owned

540
0

$685+27$
0

243

2430

Jeribs Fallowed

Owned

564

$2 n$

$\begin{array}{ll}564 & 0 \\ 20 & 0\end{array}$

1789

35

17890

Rented

20

$95+157$ 
page 23

\section{Tabie KIV}

DISTRIBUTION OF TQTAL JERIBS PLANTEC ANO TOTAL JERIBS IN FARM BEFORE TRACTOR PIJRCHASE AND IN

$$
1347
$$

Total Jeribs NORTH

Planted Before 1347 Before 131+6 Before 1347 B:fore 1347

$\begin{array}{lllllllll}0 & 1 & -- & -- & -- & -- & -- & 1 & -- \\ 1-99 & 1 & -- & 5 & 2 & 1 & -- & 7 & 2 \\ 100-199 & 6 & 2 & 1 & 1 & 5 & 2 & 12- & 5 \\ 200-299 & 2 & 4 & 2 & 2 & 4 & 4 & 3 & 10 \\ 300--399 & 1 & 1 & -- & 1 & 4 & 3 & 5 & 5 \\ 400-499 & 2 & -- & 3 & 1 & 2 & 2 & 7 & 3 \\ 500-699 & 1 & 5 & 1 & 3 & -- & 4 & 2 & 12 \\ 700-999 & -- & -- & -- & 2 & -- & 1 & -- & 3 \\ 1000-14990 & -- & 2 & -- & -- & 1 & 1 & 1 & 3 \\ 1500-1999 & -- & -- & -- & -- & -- & -- & -- & - \\ 2000-2999 & -- & -- & -- & -- & -- & - & 1 & 1 \\ 3000- & -- & -- & -- & -- & 1 & 1 & & \end{array}$

Total Jeribs In Farm

$\begin{array}{lllllllll}0 & -- & -- & -- & -- & -- & -- & -- & -- \\ 10-99 & -- & -- & 3 & 1 & -- & -- & 3 & 1 \\ 100-199 & 4 & 1 & 1 & -- & -- & -- & 5 & 1 \\ 200-299 & 3 & 3 & 2 & 2 & 3 & 3 & 3 & 8 \\ 300-399 & -- & 1 & -- & 1 & 2 & 2 & 2 & 4 \\ 400-499 & 2 & 1 & -- & -- & 2 & 2 & 14 & 3 \\ 500-699 & 3 & 4 & 2 & 2 & 6 & 6 & 11 & 12 \\ 700-999 & -- & -- & -- & -- & 2 & 2 & 2 & 2 \\ 1000-1499 & 2 & 4 & 1 & 2 & 2 & 2 & 5 & 3 \\ 1500-1999 & -- & -- & 1 & 2 & -- & -- & 1 & 2 \\ 2000-2999 & -- & -- & 2 & 1 & -- & -- & 2 & 1 \\ 3000+ & -- & -- & -- & 1 & 1 & 1 & 1 & 2\end{array}$


FARM CROP PFODUCTION -- PERCENT CHANGES IN YIELD AND CROPPING PATTERNS BEFORE AND AFTER TRACTOR PURCHASE ON FARMS OF TRACTOR OWNERS IN AFGHANISTAN

\section{OVERALL}

Change Due to Tractor Ownership

irea Production yield

\begin{tabular}{|c|c|c|c|}
\hline Irrigated i: & $15 .$. & +2.1 & +2.2 \\
\hline Dry:and reat & +1233.6 & +1423.7 & +14.9 \\
\hline Bar iy & $+4: 2.6$ & +119.3 & +54.1 \\
\hline Corn & $+2 i 0.5$ & $+37^{11} .7$ & +33.3 \\
\hline Cotton & +102.2 & +209.3 & +53.2 \\
\hline $\begin{array}{l}\text { M.nng Bans } \\
\text { Cick-P.as }\end{array}$ & $+24 ? .6$ & +10.3 .5 & .39 .5 \\
\hline Clov $\mathrm{r}$ E 4 : fidfo & +263.3 & +30.3 & -43.2 \\
\hline 0 il $82=$ is & +225.3 & +196.5 & -9.2 \\
\hline Otin: $r$ & +172.5 & $+3: 3.2$ & +34.3 .2 \\
\hline
\end{tabular}

Change NOT Due to Tractor UNaprein

$\begin{array}{rrr}\text { Area } & \text { Production } & \text { rielc } \\ -0.4 & +1.2 & +1.3 \\ +650.0 & -23.6 & -39.7 \\ +40.7 & +25.7 & -10.6 \\ +4.2 & +16.4 & +11.6 \\ +13.0 & -37.3 & -44.4 \\ -95.6 & -74.1 & +134.1 \\ +3.2 & +23.1 & +19.5 \\ +200.0 & +200.0 & N= \\ -19.6 & 116.5 & +168.4\end{array}$


TABLE XVI

A. FARM CROP PRODUCTION - PERCENT CHANGE IN YIELD AND CROPPING PATTERNS BEFORE AND AFTER TRACTOR PURCHASE ON FARMS OF TRACTOR OWNERS IN NORTHERN. AFGHAN ISTAN

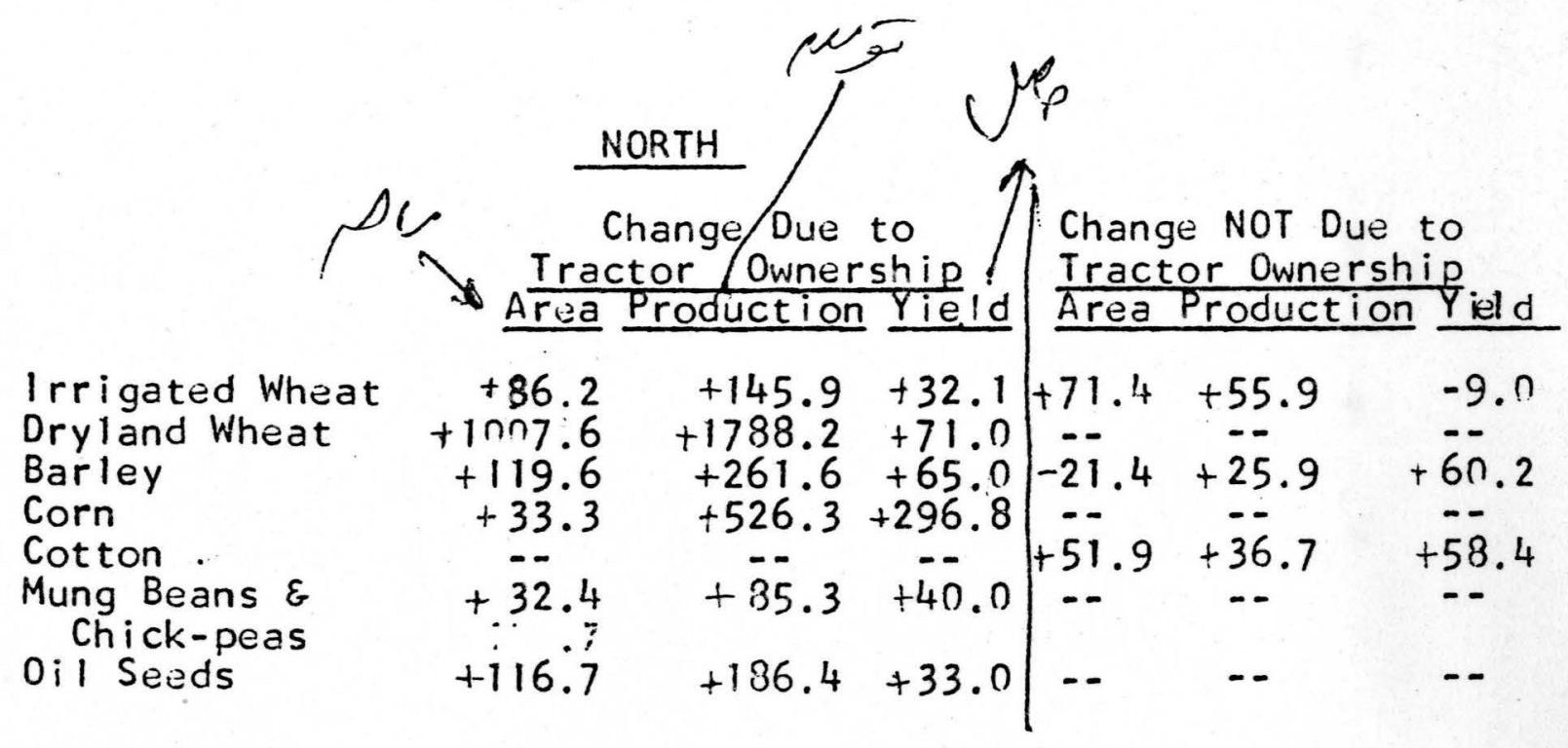

TABLE XVII

B. FARM CROP PRODUCTION - PERCENT CHANGES IN YIELD AND CROPPING PATTERNS BEFORE AND AFTER TRACTOR PUR CHASE ON FARMS OF TRACTOR OWNERS IN

CENTRAL AFGHANISTAN

\section{CENTRAL}

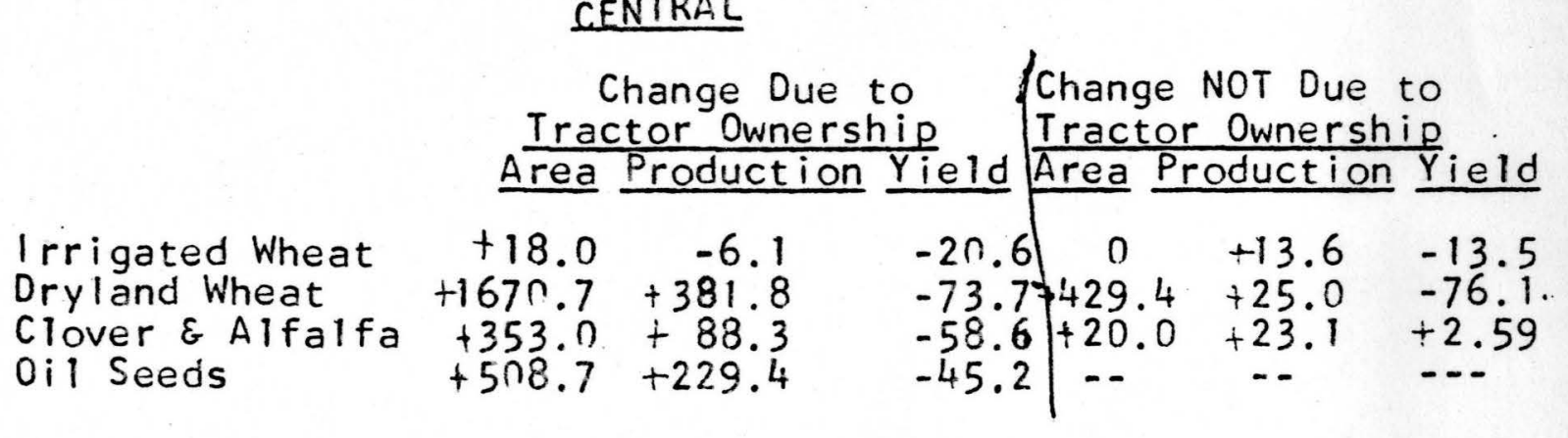




\section{TABLE XV $\| 1$}

\section{FARM CROP PRODUCTION - PERCENT CHANGES IN YIELD AND CROPPING PATTERNS BEFORE AND AFTER TRAC- TOR PURCHASE ON FARMS OF TRACTOR OWNERS IN SOUTHERN AFGHAN!STAN}

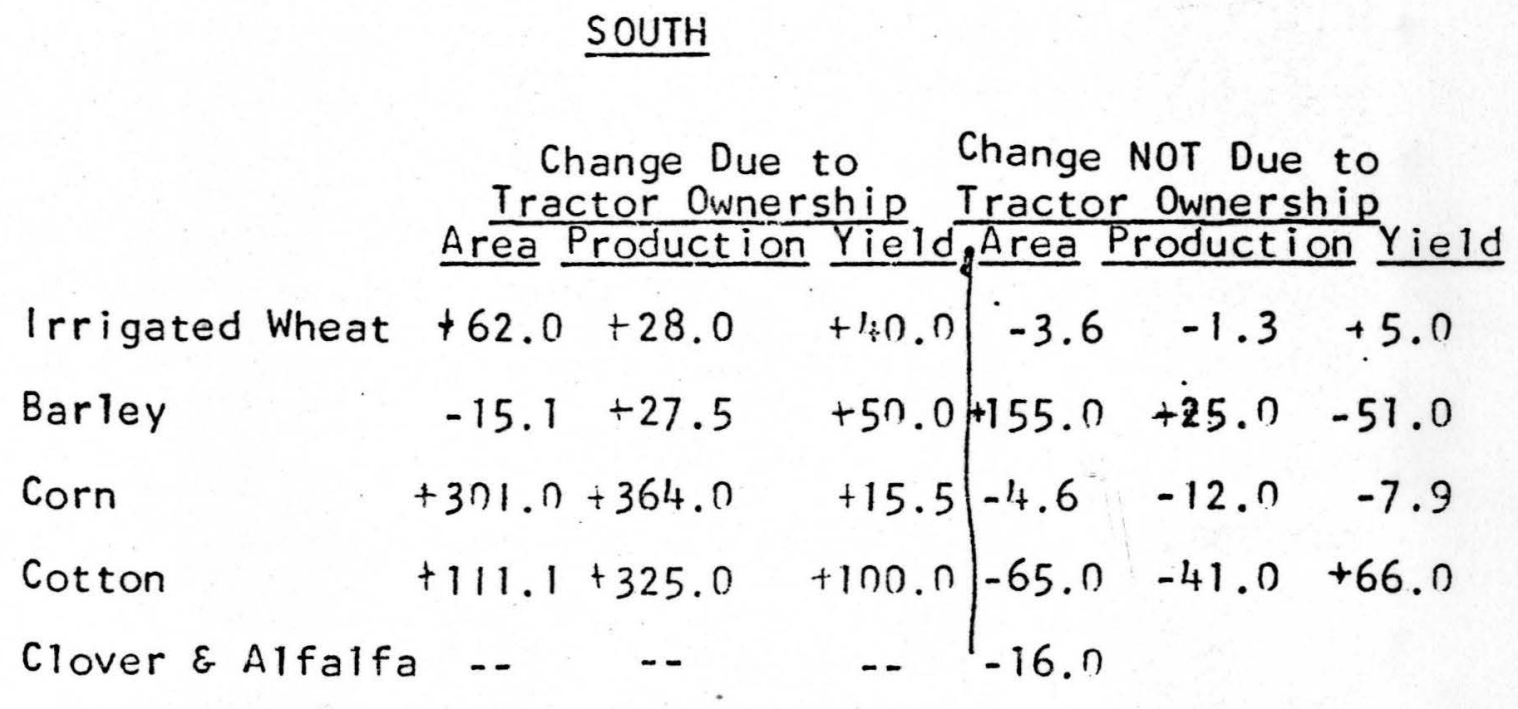




\section{On Farm Labor Force:}

Table $x \times 111$ is a two page table showing labor and anima! power requirements before tractor purchase and in $: 3 \cdot 7$. Tiere was a noticeable change in tenancy arrangements from "Ejaradar" (who usually provide bullocks as part of the tonancy agreement) to Deqan who do not provide bullocks ani consequently recieve a smaller share of crops. Over-a'l, "' Ejaradar tenants were displaced by tractors but there was an increase of 6.3 Deqan tenants for net of 33 tenants (7.5\%) replaced by tractors.

Evidence obtained during interviews shows that the percentage sinare of Deqan tenants declined, but that actua! share was greater because of increased production. This observation is not measurable.

Farm labor raquir zments increased significantly for fu: 1time laborers. Unfortunately, units do not correspond for the various arjas and changes in part-time abor cannot ba shown for the overall study. However, it is safe to say that raquiraments for part-time labor increase: more than for fu: $1-t i m e$.

On Animal Power:

Table $:$ KIII shows the total and average number of bullocks before ani after tractur ownership by area. From titis it was datermined that bul locks raplacad per tractor were 3 . "in in the north, 2 in the central area, and 6 in tha south One exceptionally large operator in the south who reported that forty bullocks were replac by his tractor was deleted from these calculations leaving an average of eight bullocks per tractor in the sout!n. 
Table $X \mid X$

Sales of Agricultural Commudities Before and After Tractor Purchase, Average Sales in Seers Per Farm, Number of Farms Reporting, Sales and Percent Change by Crop and the ther Or not Change W'as Attributed to Tractor

Ownership

Wheat (dryland E Irrigated)

Before Tractor

$13 ! 7$

Barley

$\%$ Change

Befure

1347

$\%$ Change

Corn

Befure

134.7

Cotton

$\%$ Change

Before

1347

$\%$ Change

Clover \& Alfalfa

Before

1347

$\%$ Change

Melun E WatermeIon

Before

1347

$\%$ Change

0 i1 Seeds

Before

1347

Fruits

$$
\% \text { Change }
$$

Befure

1347

$\%$ Change

Sugar Beets

Befure

1347

$\%$ Change

Mash \& Nakhod (mung béans)

Before

1347

$\%$ Change

$\theta$ thérs

Before

134.7

$\%$ Change

OVERALL

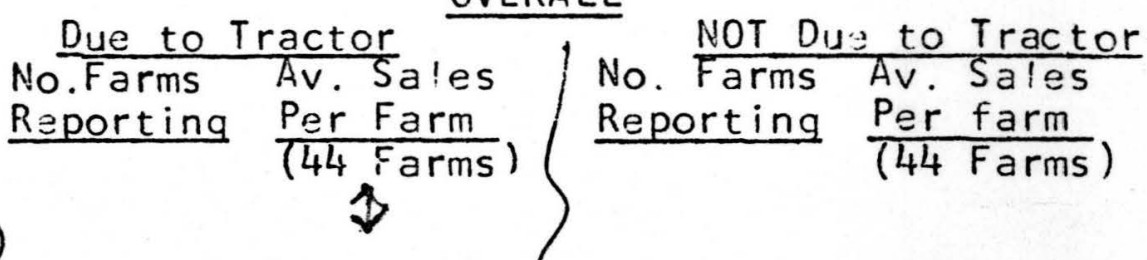

14

3

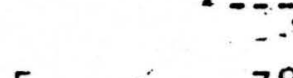

115

298

$+232$

10

10

307

583

+92 ;

45

32

$+32$

3
6

52

395

$+660$

3

3

17

23

$+65$

3

95
53

$-39$

9

7

gn6

13
$+\quad 3$

1

3

55

$+293$

149

169

$+13$

314

141

$-55$

1

2
91
+--

155

200

$+29$

--

$-$

--

3
3

$+-$

80

173

$+123$

2251

579

$-74$

19

42

* 121

3

3

140

291

$+108$
0 .3

39 
Table $X X$

Sales of Agricultural Commodities Bofore and After Tractur Purchase, Average Sales in Seers per Farm. Number of

Farms Rorting Sales and Percent Change by Crop and Whether of Not Change Was Attributed to Tractor Ownership

NORTH

Due to Tractor

No. Farms

Reporting
Not Due to Tractor

No. Farms Av. Sales

Reporting $\frac{\text { Per Farm }}{(\because \text { Farms })}$
Wheat (Dryland \& Irrigated)

Before Tractor

137

Barley

$\%$ Change

Before

Corn

$13 \div 7$

$\%$ Change

Before

$13: 7$

Cottor

$\%$ Change

Before

$13 i_{1}$ ?

$\%$ Cinange

Clover E Alfalfa

Before

$13: 7$

$\%$ Change

Melon $\varepsilon$ batermeton

Before

$13: 7$

$\%$ Cinange

Befora

$13: 7$

Fruits

$\%$ Change

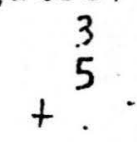

$\frac{\text { Per Farm }}{\text { (1; Farms) }}$

4

679

1250

$+34$
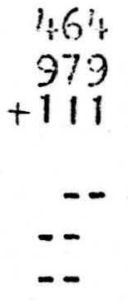

71

71
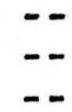

586

43
57

$-33$
Oil Seeds

Before

$13: 7$

$\%$ Change

Sugar Beot.

Before

$13^{\circ}:$

$\%$ Change

Mash E Nakhod (mung beans)

$$
\text { Before }
$$

Others

$$
\begin{aligned}
& 1347 \\
& \% \text { Cinange }
\end{aligned}
$$

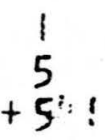

71

455

$+541$

43

129

$+200$

0
143

4

3

750

143

$-43$

226

93

$-59$

i

4

2
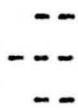

1

7075

1319

$-74$

36

57

$+53$

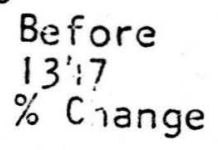

.


Table $\times$ 凅

Sales of Agricultural Commodities Before and After Tractor

Purcinase. Average Sales in Sezrs per Farm. Number of Farms

$R$ ?porting Sales and Percent Change by Crop and the ther Or Not Change Has Attributed to Tractor

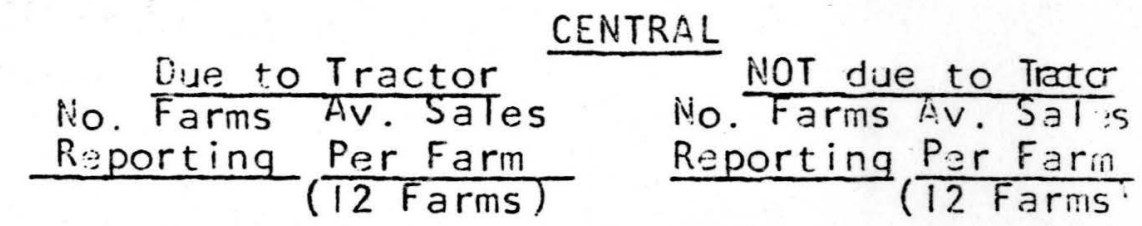

Wheat (Drylani and Irrigated)

Barley Before Tractor

$13: 7$

$\%$ Cinange

Before

$13: 7$

$\%$ Change

Corn

Before

$13 \%$

$\%$ Change

Clover and Alfalfa

Before

$13 \%$ ?

\% Change

Cotton

Before

$13 \% ?$

$\%$ Change

CENTRAL

No. Farms Av. Sal s

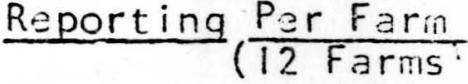

$\mathrm{Mel}$ Ion and Hatermelon

Before

$13: 7$

\% Change

oil Seerls

$B \geq$ fore

$13 \% ?$

$\%$ Change

8

144

3

7 ii

$+--$

542
-24

0

0
44

-.

I

44

0

$-$

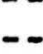

$-$

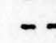

Fruits

$B \geq$ fore

$13:$

$\%$ Change

Sugar B?ats

Befor:

$13 \%$

$\%$ Change

Masin and iakhod(mung beans)

Before

$\%$ Ciange

Others

167

300

30

1
$z$

33

167

$+406$

2

4.17

Before

$13 \%$

\% Change

$\begin{aligned} & 12.5 \\ & 37 \\ + & 195\end{aligned}$
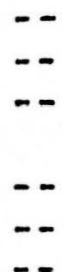

12.5

50

$+300$

2
5
+150 
Tab'e xill

Sales of Agricultural Commodities Before and After Tractor

Purchase. Average Sales in Seers Per Farm. Number of

Farms Reporting Salas and Percent Change by Crop and Whether or Not Cinange Vas Attributed to Tractor

SOUTH

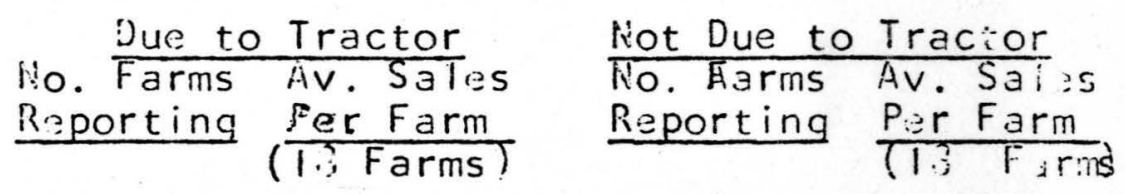

Wheat (Dryland and Irrigated)

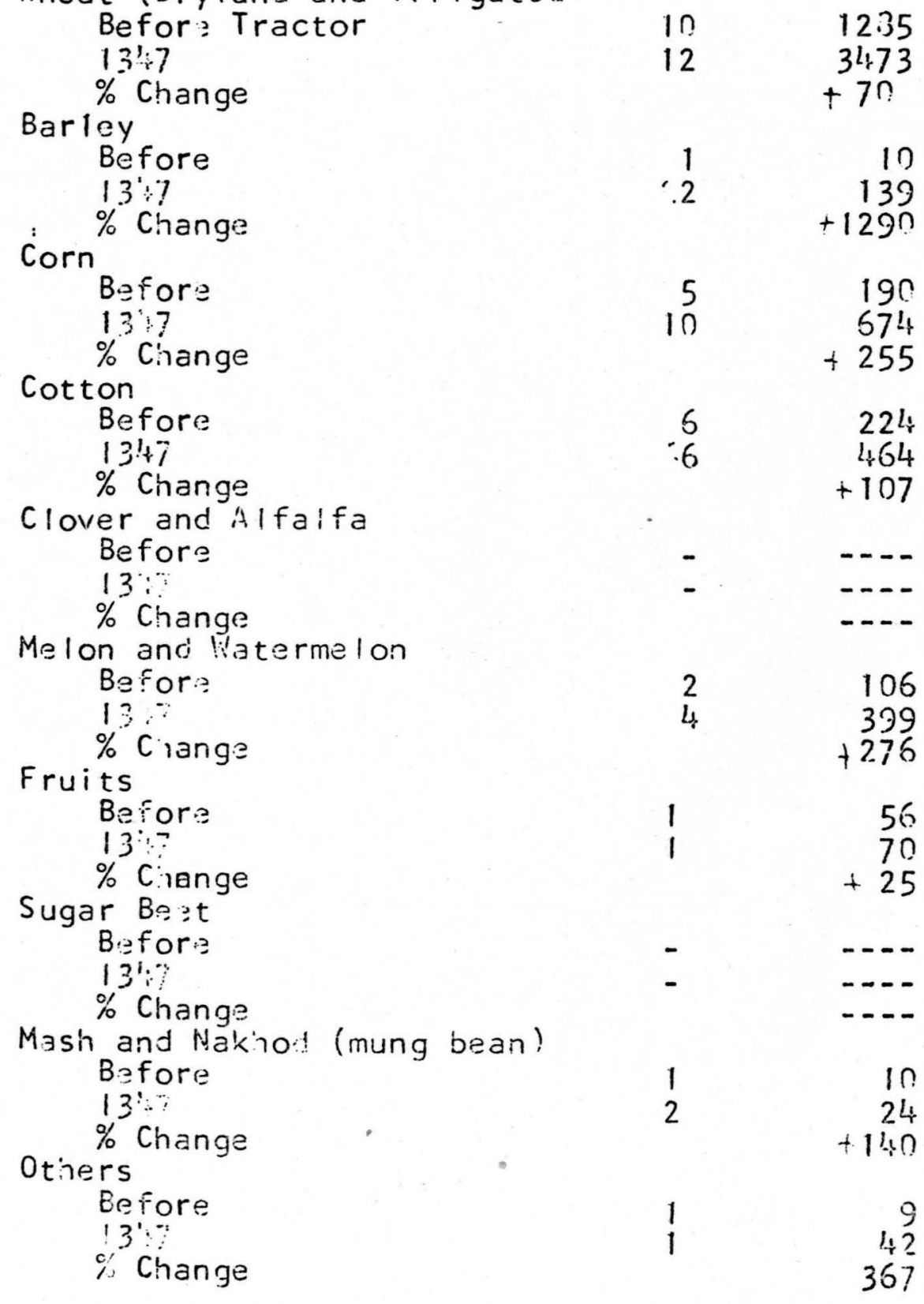

Before

$13 \% 7$

139 10

0

35

365

302

$-17$

on

$13 ! 7$

224

464

$10 \%$

5

40

$-7$

Before

$13 \%$

Befor

13

Ciang

339

2

$\rightarrow$

5 
Table $x$ iri

Labor and Animal Power Requirements Befor and After Tractor Purciace

Totals, Averages, and Percent Changes for Tenants, Laborers and Buliocks

NORTH

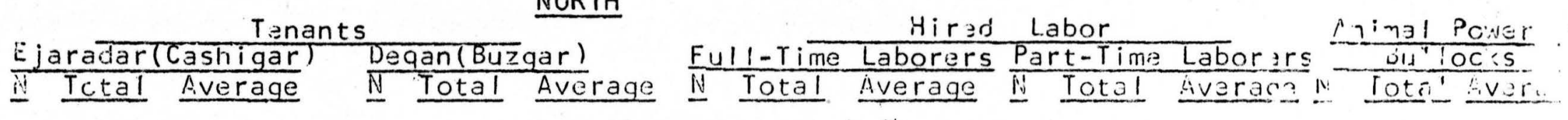

hange Due to

ractor Ownership

- Before

$3 \% 7,1$
Parcent Change

$\begin{array}{lll}5 & 1.41 \\ 5 & -60 \\ -40 & 43\end{array}$

\begin{tabular}{lr}
11 & $6 r$ \\
11 & 36 \\
$1+43$ \\
\hline
\end{tabular}

6.3

\begin{tabular}{l}
32 \\
3 \\
$2-32$ \\
\hline
\end{tabular}

$1.6 \quad 0 \quad 30$

$(2.145$

$7 \%$
$-5 \%$
$-5 \%$

hange NOT Due to
ractcr Ownersinip

Befor's

1347

Percent

\section{0}

$-20$

\section{1 \\ 1.4}

$--$

$--$

$\begin{array}{ll}6 & 13 \\ 6 & 12 \\ & -3\end{array}$

.93
.85

$\begin{array}{lll}7 & 2766 . & 177.5 \\ 6 & 3350 . & 275\end{array}$

$+39$

$\begin{array}{rrr}3 & 20 & 1.1 \\ 2 & -07 & .2\end{array}$

CENTRAL

hange Due to Tractcr Ownership

$\begin{array}{lll}\text { Before } & 13.7 & =\end{array}$

$\overline{--}$

$\overline{--}$

hange NoT lue to

racter Ownersicit?

Before

$13: ?$

Percant Ciange

$=-$

\begin{tabular}{|c|c|c|c|}
\hline $\begin{array}{l}8 \\
7\end{array}$ & $\begin{array}{r}69 \\
80 \\
+16 \\
\end{array}$ & $\begin{array}{l}5.75 \\
5.7\end{array}$ & $\begin{array}{l}2 \\
2\end{array}$ \\
\hline $\begin{array}{l}2 \\
2\end{array}$ & $\begin{array}{r}26 \\
26 \\
గ\end{array}$ & $\begin{array}{l}2.1 \\
2.1\end{array}$ & $\begin{array}{l}6 \\
6\end{array}$ \\
\hline
\end{tabular}

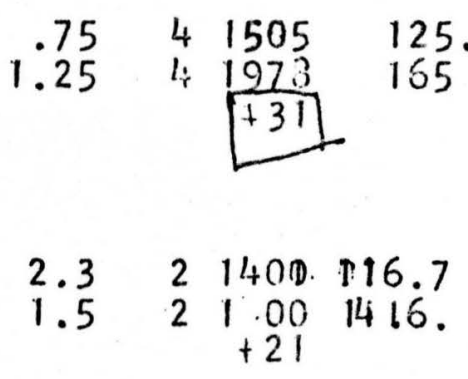

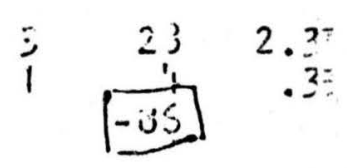

$5 . \cdots$ 
ก

0
0
0
0
South

Tenants

$\frac{\text { Tiradi }}{\text { To. } 1 \text { Average }} \frac{\text { Degan(Buzgar) }}{\text { Aotal Average }}$

Hiran Laborars Full-Time Laborers Part-Time Laborars 14 Tota! Averaqe II Total Iverage
Ciange bue ro

Tractor bwnresn : p

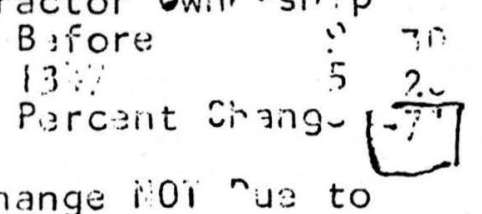

Change $\mathrm{rOi}^{\mathrm{O}} \mathrm{ie}$ to

Tractor Ginersiip

Bafore

$13: 7$

$\%$ Cinange

1 $1 i$

$2 \quad-23$

3.9

$\begin{array}{lll}12 & 119 & 6.5\end{array}$

$14 \frac{150}{+20}$

3.3

10

2 年

2.j

6.2
4.6

$\begin{array}{llcc}1.9 & 4 & 8 & .4 \\ 2.1 & 4 & 15 & .3 \\ & +37.5\end{array}$

$\begin{array}{cc}x \times x \times & x \times x \\ -1+72 & \cdots \\ -72 & \end{array}$

ind iverag

Ge!a!!

Cirange live to

Tractor 0inersiip Cinangu

Cinange MCT lue to Before

$13^{\prime}:$

$\%$ Chiange

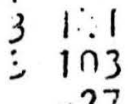

3.2
2.3

\section{1}

$\begin{array}{ll}31 & 243 \\ 32 & 316\end{array}$

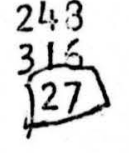

5.6
7.2

$\begin{array}{rr}15 & 72 \\ 17 & 37 \\ 27\end{array}$

$1.6 \quad 12$

2,0

13

$\begin{array}{rrr}23 & 33 & 3.3 \\ 3 & 133 & 3.0 \\ -60 & \end{array}$

$\begin{array}{rrrrrrr}5 & 61 & 1.4 & 15 & 49 & 1.1 & 17 \\ 6 & 64 & 1.5 & 16 & 45 & 1.0 & 15 \\ & 5 & & & -3 & & \end{array}$

$\begin{array}{rrr}14 & 103 & 2.3 \\ 9 & 5 & 1.3\end{array}$

Vunber of iarns reporting any tenants (or hirad labor or builocks)

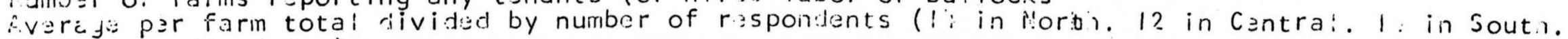
i i wera'l study.)

Man-rinys uf labor

Urils not compirable; percent is correct. 
According to respondants, the major problem of obtaining a tractor falls into the category of "problems in completing security arrangements." Generally, this refers to the red tape, waiting, and other time consuming and cost!y inconveniences at the local level. Over $30 \%$ of respondents who had problems, mentioned this general category.

The only other significant problem was that a $25 \%$ down payment was difficult to make, mentioned by 3 percent of the respondents with problems.

The major problem , in owning and operating a tractor falls in the category of inadequate parts and repair service. Spare parts seemed to be an even bigger problem than repair services. Owners had to travel long distances to obtain parts and complained of high prices. Major workshop were in Kabul, Kunduz, Masar-i-Sharif arid Kandahar. Many parts were obtained in Pakistan.

Other problems mentioned were: 1) difficulty in obtaining fuel, 2) high taxes, and 3) accidents (one owner reported three accidents which killed three drivers).

\section{Advantages of Tractors:}

Major advantages of owning a tractor, in order, as perceived by owners, are as follows:

1. Increases in land productivity.

2. Saves on labor and animal power and does not reduce income of tenants.

3. Allows more land to be cultivated.

$\therefore$ Allows reduction in number of oxen. 
Major disadvantage of owning a tractor, a check question, turned out to be the same as problems of ownership - inadequate parts and repair services. High taxes on tractors were mentioned again.

In answer to "Where did your driver learn to drive?" it was ascertained that most drivers were trained on large development projects - Nangerhar or Helmand. Some learned at various workshops.

When asked "What do farmers in your area need most to improve their farming operation and farm income?" the majority said improved seed and chemical fertilizers. Other significant replies were - more tractors and more irrigation water. The need for agricuitural extension assistance and more adequate workshops (for tractors) was also mentioned.

\section{ECONOMICS OF TRACTORS}

\section{Costs and Benefits:}

Table XXIV shows that average benefits from tractor ownership are about 47 , nnn afs per tractor per year. Tractors were most profitable in the north, quite economical in the south, but uneconomical in the central area due primarily to their high use in low return dryland wheat farming. Even if returns from custom work are considered, tractors were 4 
a losing proposition in the central area.

Table $\times X I V$

COSTS AND RETURNS FROM TRACTOR OWNERSHIP

$$
\frac{\text { NORTH }}{A \text { fs/year }} \frac{\text { CENTRAL }}{\text { Afs/year }} \frac{\text { SOUTH }}{\text { Afs } \% \text { OVERALL }}
$$

\section{Cost:}

Operating Expenses

Depreciation

Total

Returns:

Benefits from

Extra Production

Saving on Oxen

Maintenance

Depreciation

Total

Returns Less Cost

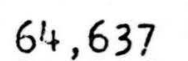

27,000

9i, 637,

$71: 444$

$1,2,00 n$

92,365
12,000

77,337

$173,4+4$

134,365

37.227

$115, \cap 6 !$

$\begin{array}{rrrr}197,107 & 10,700 & 166,513 & 133,753 \\ 19.721_{1} & 10,220 & 40,830 & 25,737 \\ 1,930 & 1,000 & \because, 000 & 2,523 \\ 218,761 & 21,920 & 211,393 & 162,063 \\ +127,124 & -91,524 & +77,023 & +46,999\end{array}$

Table 111 shows average use for custom work to be 15.7 days per year. If tractors are paid for ten hours per day for 15.7 days of custom work per year, they will earn about $2 !, 0 n n$ afs per year at the average rate of 153 afs per hour shown in Table IV.

When custom work earnings are considered, behefits from tractor ownership should be valued at 1i5, 34.7 afs per year in the north, 35,023 in the south, and a loss of 67,503 in the central area.

The poor showing of tractors in the central area is partially explained by the fact that they are used a great deal on dryland wheat -. a rather uncertain and low yielding enterprise. See Table VIll which shows that on average over 7 percent of the land on which tractor was used was planted to dryland wheat (539 jeribs of dryland wheat out of a total 
of 761 jeribs). Clover and alfalfa cultivation was also important in the central area, and this is not usually a good money crop in Afghanistan. Enumerator observation in the central area is that tractors are frequently used on widely separated fields. Table 11 shows that average monthly tractor use is excessiveiy high (132.6 hours per month equals over 2 , non hours per year - 1200 hours per year is considered high in the U.S.).

For Table XXIV, the follewing prices were used to calculate benefits from changes in production.

$\begin{array}{llll}\text { Wheat } & 30 \text { afs per seer } & \text { Melons } & 6 \text { afs per seer } \\ \text { Barley } & 12 \text { afs per seer } & 0 i 1 \text { seeds } & 33 \text { afs per seer } \\ \text { Corn } & 15 \text { afs per seer } & \text { Fruits } & 20 \text { afs per sear } \\ \text { Cotton } & 50 \text { afs per seer } & \text { Mung Beans } 40 \text { afs per seer } \\ \text { Clover } & 3 \text { afs per seer } & \text { Others } & 10 \text { afs per seer }\end{array}$

These prices are approximations made from prices during $13+5$ and 1346 obtained from the Kabul Weekly Retail Price Report (USAID/Agriculture Division) and adjusted for farm price, mostly on the basis of the author's experience. Information from The Place of Cotton and Beet Sugar in the Economy of Afghanistan by Allanson and The Cotton Supply Response to Price Cinanges by Keshawarz anu Saunders (Ministry of Planning) was also usad.

Costs of maintenance per oxen were $1 / 4$ afs per day in all areas. This is based on information from a study of Costs and Returns for Wheat Production done by Dawlaty, Saleh and Owens. Oxen depreciation was taken from the same source. 
Generally speaking, tractor ownership is practical on larger farms capable of intensive cultivation. Additional imports of tractors and implements, if properly placed and used, wili be important to agricultural development in Afghanistan.

Tractor use, in terms of hours par month or hours per year, is high in Afghanistan, especially in the central area. Tractor use is spread fairly evenly throughout the spring, summer and fall months except in the south where most of the work is during the fall monthe. Tractors are used least in the winter, as would be expected.

Plowing is the most important tractor operation in terms of hours used, with hauling second. In view of the high number of hours tractors are used, there is some question as to whether hauling is the second best use for tractors.

In the over-all study, tractors are used on more jeribs of wheat than jeribs of all other crops -- almost 75 percent of the acreage on which tractors were used was wheat land. About 41 percent of this wheatland was dryland acreage, which usualiy gives poor returns. Almost $9 n$ percent of all dryland acreage was in the central area.

The most used imp? ements, according to operators, are the plow and field cultivator or tiller (the tiller was not part of the imp'ament package for Byelarus tractors). 
Least used implements are the blade and disc harrow. Farmers showed a great deal of interest in threshing machines, greim drills and ridger-ditcher attachments when asked what implements they would like to buy. A stationary threshing machine which could be powered by the tractor can probably be obtained at a reasonable price from Pakistan. Threshing machines would replace a great deal of labor, the wisdom of which has been questioned in Afghanistan. Although no measures of unemployment and underemployment exist, they are certainly problems. On the other hand, labor shortage at harvest time is also a serious problem in many areas.

Tractor owners are generally optimistic regarding useful 1 ife of tractors. Most of the tractors in this study will not be useful after ten years of $1 \mathrm{ife}$.

Costs of operating tractors, as reported in this study, are low compared to costs in the U.S.A. for comparable tractors. This is especially true for the north and central areas. This is probably partly due to under reporting of costs, partly to inadequate maintenance and partly to lower fuel and labor costs.

Major problems, according to tractor owners themselves, were encountered in: 1) completing security arrangements for the bank before taking delivery of tractor and 2) obtaining spare parts. The major advantages were: 1) increased land productivity and 2) savings of labor and animal power. Improved seed and fertilizer were seen as the greatest need for improvements in farming. 
Significant increases in production and sales were attributed to the tractors in the north and south. Value of additional production was about $127,00 n$ afs per year in the north and 77 , non afs per year in the south.

On the balance, very little if any human labor was replaced by tractors. There was a noticeable shift from "Ejaradar", who usually provide oxen as part of the tenancy. agreement, to "Deqan" who are more on the order of fulltime laborers. Tractors replaced an average of 3.3 bullocks per tractor in the notth, 2 in the central area, and 8 in the south. This amounts to an average of 5.8 bullocks per tractor for the overall study.

Tractors were very economical in the north, economical in the south, and uneconomical in the central area where tractors were used heavily in low return dryland wheat production. Generally speaking the north is the mcst productive area with reference to water availability, climate and soils, and the central area is least productive. In addition, the tractors in the north have been in use longer. !t is unlikely that tractors will ever be economicel for dryland wheat farming in Afghanistan.

This study points out several things which should be considered seriously in determining agricultural future policy.

1. Some attempt should be made to provide better information to tractor owners and tractor drivers regarding proper and best use of their machines. and implements. Apparently, many tractors do not receive proper maintenance. 
Perhaps this could be done with information bulletins prepared in cooperation with the new workshop-school on the Ministry of Agricultura Daralaman Farm.

2. Assistance in improving parts availabllity and repair service is a strongly felt need on the part of the farmer. Means should be sought by which this can be dor 1; perhaps through encouraging private enterprise.

3. Consideration should be given to a revised implement package -- certain items such as disc and scraper should be optional and other items should be available if the operator wishes to purchase them.

4. Tractor purchase by dryland wheat farmers should be discouraged and care should be taken to place tractors on land which can be more intensively cultivated.

5. An equ table policy for determining who receives 1 tractors should be devised on the basis of type of farm, size of farm and location as well as operator's ability to pay. Red tape and other inconveniences should be reduced as much as possible, especially at the local administrative level. Current prices and interest rates seem reasonable, but ways of reducing costs to farmers are desi reable. 
WATER PUMPS

Twenty-seven water pump owners were interviewed who owned a total of forty-eight water pumps -- 1.73 pumps per farm. Some of the pump owners were reporting for their partners, so the concept of 1.78 pumps per farm is somewhat inexact. Thirteen sole proprietors reported owning a total of twenty-four pumps. The remaining twenty-four pumps were owned by 196 persons, some of whom owned as smal1 as one-sixteenth share.

Most of the pumps were made in Pakistan! four were from the Soviet Union, two from Czechoslovakia and one from Japan. Twenty-four of the forty-one Pakistani pumps were of the Bece $20 \mathrm{HP}$ type. Only nine of the forty-eight pumpswere "portable"; the rest were stationary. Table XXV gives details of pump types. All pumpswere powered by diosel motors.

Only the Beco $20 \mathrm{HP}$, Beco $7 \frac{1}{3} \mathrm{HP}$ and Soviet $14 \mathrm{HP}$ pumps were imported by the Bank. There were twenty-eight such pumps in this study; the other twenty pumps had been imported privately.

Eight of the forty-eight pumps were not operating for want of a well or repairs.

Utilization:

The Beco pumps were operated an average of 110 days. per year and all pumps in the study averaged 93.4 days operation per year. Average hours of operation by season, for all pumps, ranged from 9.2 yours per day in the spring to 
11.5 hours in the summer to 16.0 hours per day in the fall (See Table XXVL)! Peak water use in Afghanistan is generally in the spring and summer. The reason for the more intensive pump use during the fall is that traditional water sources are prone to dry up as the seasons progress. None of the pumps were used during the winter.

Table XXVII shows that pumps were used primarily to irrigate wheat, which is usually irrigated before and after planting in the fall. Types of crops irrigated by water pumps correspond closely to types of crops on which tractors were used in the central area axcept in the case of dryland wheat, which is excluded from the pump study by definition.

None of the pump owners in this study sold water to other farmers or landowners (except their own tenents.)

\section{Costs:}

Pumps were sold on the same terms as tractors for the following prices.

$$
\begin{array}{ll}
\text { Beco } 20 \mathrm{HP} & 33,955 \text { afs } \\
\text { Beco } 7 \frac{1}{3} \mathrm{HP} & 54,541 \text { afs } \\
\text { Soviet } 14 \mathrm{HP} & 43,081 \text { afs }
\end{array}
$$

Prixes of pumps not imported by the Bank are not known. As with tractors, pump owners tended to be overly optimistic regarding useful 1 ife and saivage value of pumps.

Calculations in this study were based on a salvage value of 10 percent at original cost and in years of useful life. 
Table XXV111 shows costs for three horsepower categories of pumps and average yearly costs for all pumps. The figures show that operating costs were higher for 13-16 HP pumps than for 18-20 HP pumps. However, the depreciation is much lower when the price for the Soviet 14 HP pump is used.
Average operating expenses are about thirty afs
per hour per pump for all pumps. By horsepower category, they are:

$\begin{array}{ll}18-20 & 26.6 \\ 13-16 & 34,1 \\ 7 \frac{1}{2}-10 & 25.3=\end{array}$

According to these figures, the 13-20 pumps, particularly the Beco 20, are most economical. This is corroborated by the fact that half the pumps in the study are Beco 20's and most operators prefer Beco 20's or similar pumps if they intend or want to buy another pump.

Costs of well, including pipe and installation, were a very large item, averaging almost 50,000 afs per we11. Most of the wells were dug by the owners with the help of hired labor (19 of 36 reporting). Twelve of thirty-six owners dug the wells themselves (probably cooperative projects among multiple ownership pumps) and 5 of 36 were dug exclusively by hired labor. Thirtythree of thirty-eight wells: were hand dug to an average depth of 14.56 meters. The remaining fifteen were hand dug to an average depth of 14.3 meters and then extended 
Table XXV - Number and Types of Water Pumps in Study

\begin{tabular}{|c|c|c|c|c|c|c|c|c|c|c|c|c|}
\hline \multirow{3}{*}{$\begin{array}{l}\text { Brand Name } \\
\text { Beco }\end{array}$} & \multirow{3}{*}{$\begin{array}{l}\begin{array}{l}\text { Country of } \\
\text { Manufacture }\end{array} \\
\text { Pakistan }\end{array}$} & \multirow{2}{*}{\multicolumn{6}{|c|}{$\begin{array}{c}\text { Number of Pumps in Study } \\
\text { by } \\
\text { Horsepower Rating }\end{array}$}} & & & \multirow{3}{*}{ 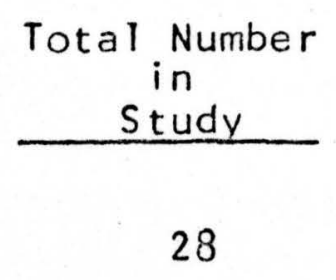 } & \multicolumn{2}{|c|}{ Nuniver } \\
\hline & & & & & & & & & & & Portable & Fixed \\
\hline & & $\frac{20}{24}$ & $\frac{13}{9}$ & $\frac{16}{1}$ & 15 & $\frac{14}{!}$ & $\frac{13}{i}$ & $\frac{10}{i}$ & $\frac{7.5}{3 .}$ & & 4 & 24 \\
\hline Atifaq & Pakistan & & & 4 & & & & & & 4 & & $\iota$ \\
\hline Badder & Pakistan & & 1 & & 1 & 1 & & & & 3 & & 3 \\
\hline Matchless & Pakistan & 3 & 1 & & & & & & & 4 & & 't \\
\hline Nessar & Pakistan & & & & & 1 & & & & 1 & & 1 \\
\hline Hussain & Pakistan & & 1 & & & & & & & 1 & & 1 \\
\hline$?$ & Soviet Union & & & & 1 & & 3 & & & 4 & 4 & \\
\hline$?$ & Japan & & & & & & & 1 & & 1 & & 1 \\
\hline$?$ & Crechos lovaki & & & 2 & & & & & & 2 & 1 & 1 \\
\hline All Pumps & & 27 & 3 & 7 & 2 & 2 & 3 & 1 & 3 & 48 & 9 & 39 \\
\hline
\end{tabular}


Table XXVI

WATER PUMP OPERATION -- DAYS OPERATED PER

YEAR AND HOURS PER DAY BY SEASON, BY TYPE OF PUMP

\begin{tabular}{|c|c|c|c|c|c|c|c|}
\hline \multirow[b]{2}{*}{ Beco } & \multirow[b]{2}{*}{ Pakistan } & \multicolumn{2}{|c|}{$\begin{array}{l}\text { Days Per Year } \\
\text { Of Operation } \\
\text { Av. Range }\end{array}$} & \multicolumn{4}{|c|}{$\begin{array}{l}\text { Average Hours Per Day } \\
\text { Of Operation } \\
\text { Spring Summer Wall Winter* }\end{array}$} \\
\hline & & 110 & $20-235$ & 10.5 & 10.6 & 14.3 & 0 \\
\hline Atifaq & Pakistan & 135 & $90-180$ & 18.2 & 23.0 & 18.2 & 0 \\
\hline Badder & Pakistan & 115 & $105-120$ & 13.6 & 8.0 & 17.3 & 0 \\
\hline Matchless & Pakistan & 126 & $80-13 n$ & 23.0 & 12.0 & 23.0 & 0 \\
\hline Nessar & Pakistan & 80 & & $23.0-$ & & 23.0 & 0 \\
\hline \multirow[t]{3}{*}{ Hussain } & Pakistan & 135 & & 22.0 & & $22 . n$ & 0 \\
\hline & Soviet Union & 75 & $3 n-120$ & 2.0 & 12.0 & 11.3 & 0 \\
\hline & Japan & 135 & & 22.0 & & 22.0 & 0 \\
\hline & Czechoslovakia & 98 & $90-15 n$ & 6.0 & 23.0 & 14.5 & $n$ \\
\hline A11 Pumps & & 93. & & 9.2 & 11.5 & 16.0 & \\
\hline
\end{tabular}

* None of the pumps were operated during the winter.

TABLE XXVII -- JERIBS OF VARIOUS CROPS IRRIGATED BY WATER PUMP (1347).

Crop N Total Jeribs Av. Jeribs/Farm Av. Jeribs/Pump

$\begin{array}{lrcr}\text { Wheat } & 26 & 3,576 & 132.4 \\ \text { Alfalfa \& Clover } 13 & 472 & \frac{17.5}{2.9} \\ \text { Melons } & 6 & 77 & 4.1 \\ \text { Corn \& Barley } & 7 & 109.5 & .3 \\ \text { Vegetables } & 3 & 9 & 10.3 \\ \text { Others } & 6 & 273 & \end{array}$

$N$ Number of farms reporting

Average jeribs per farm = total jeribs +27

Average jeribs per pump $=$ total jeribs +43 
Table XXVIII -- Costs of Operation - Pumps

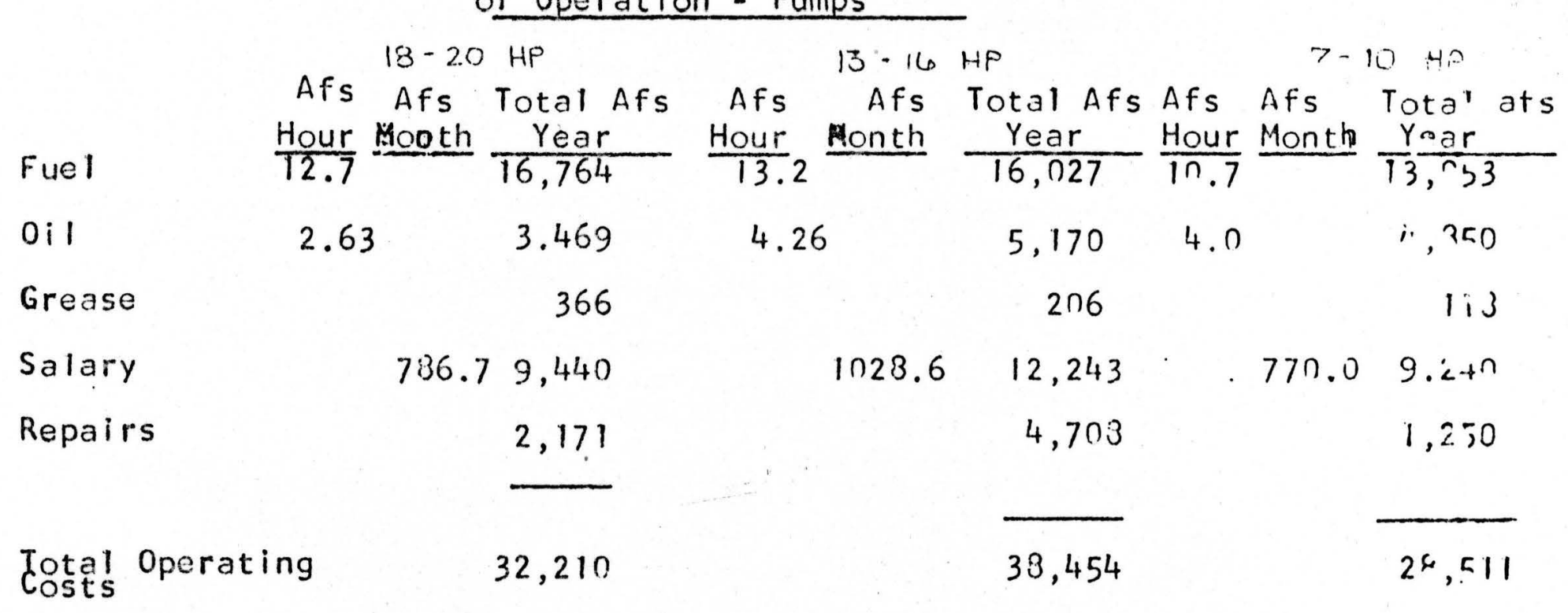

\section{(Cont) \\ All Pumps Afs Per Year \\ Fuel \\ $0 i 1$}

Grease

Salary

Repairs

Total Operating

Costs 
12.7 more meters (total depth 27 meters) by mechanical spudding or sinking iron tubing. Wells are usually round 3-4 meters in diameter with a rectanguar or square shelf $3 \times 4$ to $4 \times 5$ meters, where the pump is placed about bilf-way down. A ramp is usually dug down to the pump beginning about 13-30 meters from the well site.

Tube wells of comparable depth would probably cost considerably less if drilled with modern machinery. Effects of Pumps: (On Area Planted Annually);

Apparent1y, water pump owners increased their acreage of all crops because of pump ownership. In most cases, production also increased, but yields decreased on all crops except vegetables. See Table $x \times I X$. This indicates that the expected (or hoped for) amount of water was not forthcoming - over-optimism again. Some operators did not get enough water because the well was inadequate and some pumps were innperable for lack of repairs. Another factor causing low yield-per jerib is the new non-previously-cultivated land $\int$ brought under irrigation by water pump. Those lands are usually poor physically and low in organic matter. Twenty- $\}$ four of the twenty-seven owners said irrigation water was inadequate for their land and fourteen of the twenty-four attributed this shortage to inadequate water from their well. (On Crop Production And, Yieids; )

The 243.3 percent increase in wheat production alone represents a value (of increased production) of over 23,000 afs 
per year per pump. Net value of increases and decreases in production, 28,306 afs per pump per year, is shown in the section on Economics of Pump Utilization. See Table XXXIII. (On Sales of Farm Products;)

Sales of the following commodities increased, and most of the increases were attributed to tractor ownership:

$\begin{array}{ll}\text { Wheat } & \text { Melons } \\ \text { Corn } & \text { Alfalfa and Clover } \\ \text { Legume Crops } & 0 i l \text { seeds } \\ \text { Vegetables } & \text { Tobacco }\end{array}$

There were no decreases in sales. Value of the increased sales which were attributed to pump ownership was about 7,300 afs per year per pump of 13,900 afs per year per farm, about 27 percent the value of increased production. This is shown in Table $x \times x$.

Table $X X \mid$ shows that jeribs irrigated almost quadrupled after pump purchase, according to operators definition. Jeribs planted more than doubled. Jeribs of owned dryland declined by about 45 percent but jeribs fallowed increased greatly. Operators probably classify this as "irrigable" Iand for which there wasn't sufficient water. Virtually all changes in land use shown in Table $X X X \mid$ were attributed to pump ownership.

(On Farm Labor Force;)

Table XXXIl shows that all categories of tenants, laborers and bullocks increased when change was attributed to pump ownership. This change was most apparent in the Degan tenant category. There were no ejaradar tenants. 
Tabie $X x \mid X$

Farm Crop Production - Total Area Planted and Yield, Before Pump Purchase and ii) 1347

Wheat

Before

1347

$\%$ Change

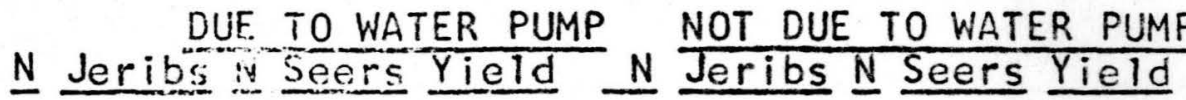

$\begin{array}{llllllllll}14 & 784 & 14 & 16680 & 21.3 & 4 & 635 & 4 & 15900 & 25.0\end{array}$

$\begin{array}{lllllllll}19 & 3988 & \text { is } & 57260 & 14.45 & 542 & 5 & 15705 & 29.0\end{array}$ $+408.7+243.3-32.4-14.6^{5}-1.2+16.0$

Dryland Wheat

Before

1347

$\%$ Change

$\begin{array}{llllrrrr}2 & 720 & 2 & 3500 & 4.97 & 8927 & 3150 & 3.5 \\ 2 & 3000 & 2 & 2140 & 2.7 & 5 & 1068 & 6 \\ & +11.1^{2} & -38.9 & -44.9 & +19.7 & -78.3 & -82.9\end{array}$

Alfalfa \& Clover

Before

1347

$\%$ Change

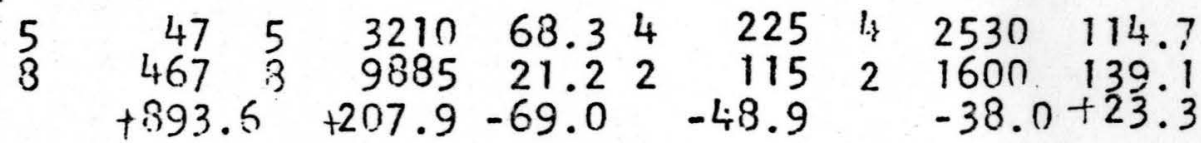

Melons

Before

1347

$\%$ Change

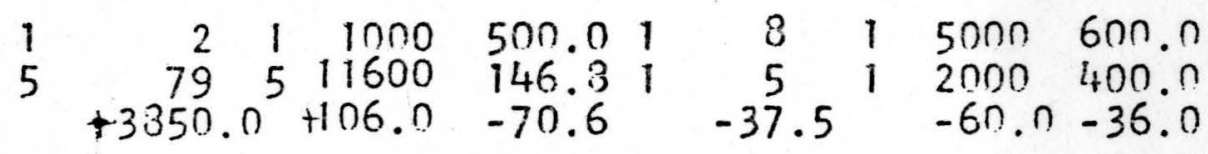

Corn E Barley

Before

1347

$\%$ Change

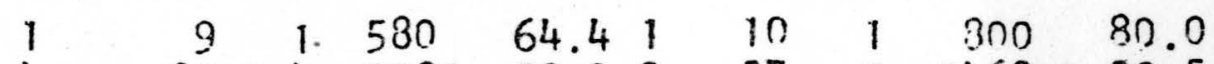

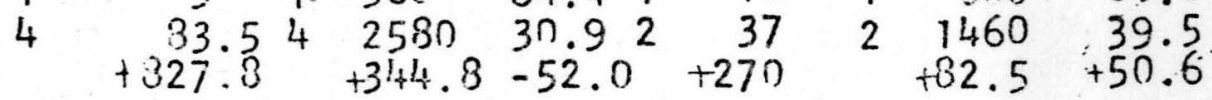

Vegetables

Before

1347

$\%$ change

$\begin{array}{ccccc}2 & 4.252 & 450 & 105.9 \\ 5 . & 13.5 & 5 & 2340 & 126.5 \\ & 3335.3 & +420.0 & +19.5 \\ & & & & \\ 2 & 39 & 2 & 570 & 14.6 \\ 2 & 270 & 2 & 1900 & 7.0 \\ & +592.3 & +233.3 & -52.1\end{array}$

Others

Before

1347

$\%$ Change

ther Legumes

Before

1347

$\%$ Change 
Table $\mathrm{x} x \mathrm{X}$

Sales of Agricultural Products Before and After Pomp Purchase Average Sales Per Farm. Number of Farms Reporting Sales.

Percent Change and Whether or Not Change was Due to Pump Ownership

$$
\frac{\text { Due To Pump }}{\text { No. Farms Av. Salest Not Due To Pump }}
$$

Wheat Dryland \& Irrigated Forting (seers) Reporting Farm(seers

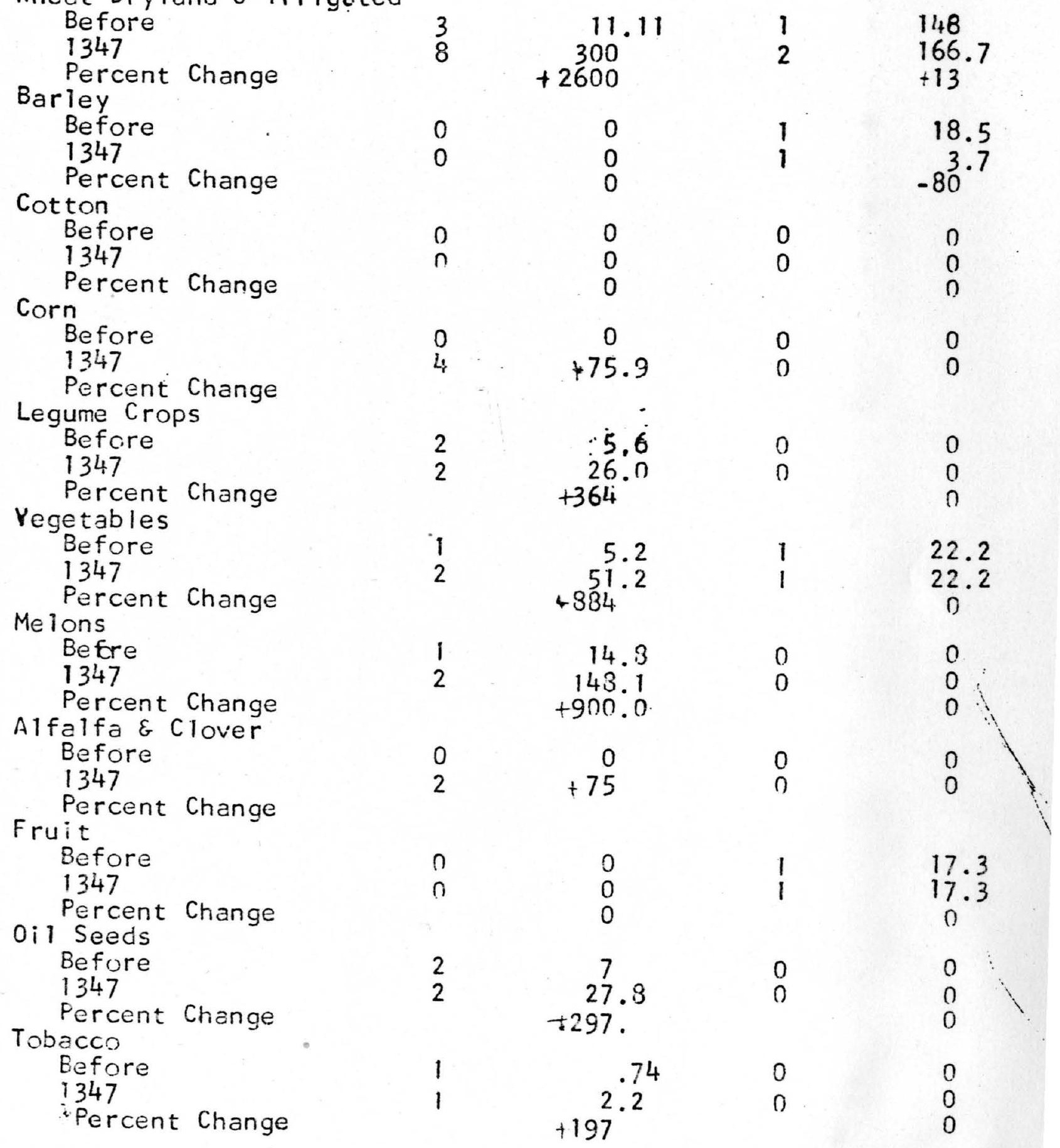


Table $X \times X 1$

Total Jeribs Irrigated, Total Jeribs Dryland, Total Jeribs Planted, and Total Jeribs Fallowed on Farms of 27

Water Pump Owners Before Pump

Jeribs Irrigated

Owned

Rented

Jeribs Dryland

Dwned

Rented

Jeribs Planted

Owned

Rented

Jeribs Fallowed

Owned

Rented

$N=$ Number of farms reporting
N $\stackrel{1347}{\text { Total }}$

$\begin{array}{llll}20 & 5627 & 26 & 21921\end{array}$

$14 \quad 7123$

11

3799

$23 \quad 3471$

27

9301

13961

16

3030 
Table $x \times x \mid 1$

Labor and Animal Power Requirements on Farms of Water Pump Owners

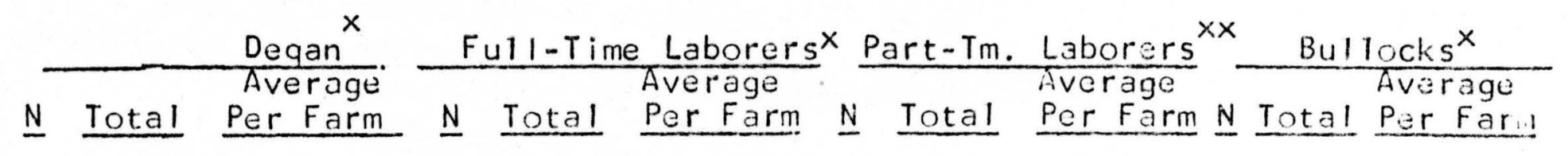

Due to Pump Ownership

Before
1347
Percent Change

$\begin{array}{rr}6 & 21 \\ 12 & 142 \\ +576.2\end{array}$

$\begin{array}{llcccccccc}.8 & 1 & 3 & .1 & 2 & 740 & 27.4 & 6 & 44 & 1.6 \\ 5.3 & 3 & 17 & .6 & 5 & 2435 & 90.2 & 3 & 73 & 2.9 \\ & & +466.7 & & & +229.1 & & +77.3 & \end{array}$

Not Due to Pump

Ownership

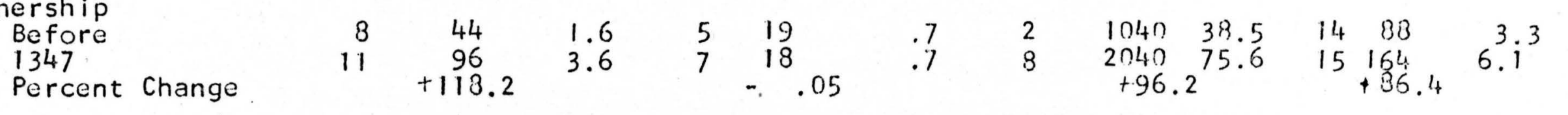

$\times$ Number of workers or animals per year 'xx Man-Days per year

$N$ Number of farms reporting

Average per farm $=$ Total +27 
Farmer's Attitudes, Opinions and Problems:

(Problems of Pump Ownership;)

Eleven of thirteen pump owners who reported problems in obtaining their pumps listed difficulty "in completing security arrangements" which may be defined the same as for tractor owners -- red tape, waiting, and "other costly and time consuming factors".

Major problems in operating the pumps were shortage of spare parts and inadequate repair service. Land dispute problems and disagreement among owners were mentioned and "we11 not deep enough". (Advantages of Motor Pumps:)

The major advantage of o:ming a water pump was reported to be "adds new land to previous holdings" ( $2 n$ of 27 replies). Seven operators reported that "it increases production". The major disadvantage was reported as difficulty in obtaining parts and repair service.

Pump owners were asked what farmers needed most to improve their farming operations and farm income. The significant replies, in order of importance, were:

1. Workshops and mechanics

2. More water for irrigation

3. Spare parts for farm equipment

4. Drilling machinery to increase water supply

5. Tractors

The also mentioned need for improved seeds, fertilizer, fuel stations, fruit trees and assistance in constructing wells. 
Economics of Motor Pumps:

(Costs and Benefits;)

From the standpoint of our analysis, water pumps are not economical in the study area. Table XxXIll shows a net annual loss per farm of over 23,000 afs. While this analaysis does not take account of the costs of traditional water saved by pumps, neither does it take account of the extra costs occasioned by an increase in labor and animal power. These are unknown on unassignable quantities, but would tend to counterbalance each other.

There are, however, other considerations. The quantity of ground water for wells and pumps is not known -- how many wells and pumps will this water supply support and for how long. Regardless of costs and returns, this information must be obtained before decisions can be made regarding future pump use in this area.

Assuming the water supply is adequate for a given number of pumps for a reasonable period of time -- say forever -a strong case for pumps may stil! be made for two reasons:

1. Reclaimed land will undoubtedly increase in value -- probably enough to offset the costs of pumps and initial decreases in yeilds.

2. The efficiency of farming on reclaimed land will probably improve with time. Much of the new land currently in use is only partially developed. When asked about plans 
for improving their farm operations, 17 of the 27 respondents said they had definite plans to use improved seed (wheat seed) and were able to teli us how many seers they planned to use. Ten of these people also planned to use chemical fertilizer. Thirteen respondents were using or planned to use insecticides for specific purposes which they were able to state.

Table XxXIV is a distribution of farm size and jeribs planted. Unlike the situation for tractors, pumps are not necessarily most economical on larger acreage. Expert opinion is needed on amounts of water needed per jerib of

- various crops and how much water the various pumps can. supply.

\section{Summary and Conclusions:}

The Becn 20 HP pump or its equilavent in other brands seems to be the most popular and most economical.

Peak pump use is in the fall and the water is used mostiy for wheat. None of the pumps are used to supply water to persons aher than the riwiers.

Costs of pump operation average over $33,7^{\mathrm{n} n}$ afs per year of about 30 afs per hour. No bas is of comparison was available to the authors. Costs of digging wells (which are probably not deep enough even at inn feet) were found to be about 47,5 nn afs which is probably excessive.

As a result of purnp ownership, area planted generally went up and production increased somewhat less, causing a decline in yields. Net value of changes in production amour:- 
ed to about 28,806 afs per pump per year, about one-fourth of which was sold. Most of the increases in production and sales were from wheat.

Jeribs irrigated almost quadripled, jeribs planted more than doubled, owned dryland acreage declined and jeribs fallowed increased.

All categories of tenents, laborers, and animal power increased, particularly tenants.

Farmers major problems were completing security arrangements and inadequate parts and repair service.

Major advantage was seen to be that the pumps add to landholdings and that pumps increase total production (but not productivity).

Farmer's most pressing needs seemed to be workshope and mechanics, additional irrigation water, and spare parts.

Pump irrigation was not economical in the study area but this may be mitigated by the facts that production will probably increase in a few years after the land is fully developed and that the value of reclaimed land will probably increase. At present farmers lack experience with pump irpigation and have tried to utilize more land than the pumps will supply water for. Farmers should be encouraged to use pump irrigation on high value crops. It has been repeatedly shom in other countries that pump irrigation is economically unfeasibie on low value crops. 
Table $x \times x \mid 11$

Costs and Returns from
Pump Ownership

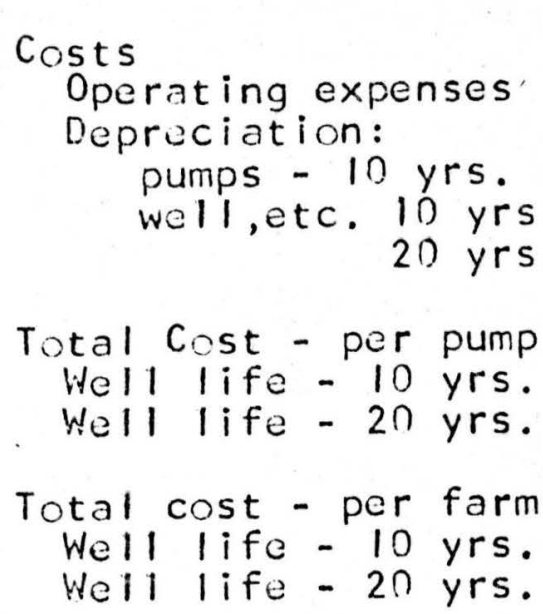

$18-20 \mathrm{HP}$
32,210
10,000
5,430
2,715
47,640
44,925
34,704
79,377

$13-16 \mathrm{HP}$
38,455
6,000
5,233
2,119

$7 \frac{1}{2}-10 \mathrm{HP}$

A11 Pumps

33,723

6,500

1. 428

714

3, 541

4,749

2,374

$36,+39$

47,013

49,693

$35,3 \cap 9$

44,638

Returns from extra

Production - per pump

per farm

Returns less cost - afs/farm

Well life - 10 yrs.

Well life - 20 yrs.

38,354

82 , ing
$6 !, 361$

63,519
33,539

79,366

23,806

51.210

$-32,379$ 


\section{Table XXXIV \\ Land Use Distribution - Farms of Water Pump Owners}

Total jeribs planted:

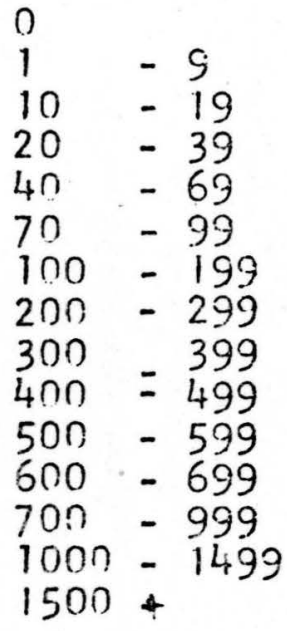

$\frac{\text { Before }}{4} \quad \frac{1347}{0}$

Total jeribs in farm:

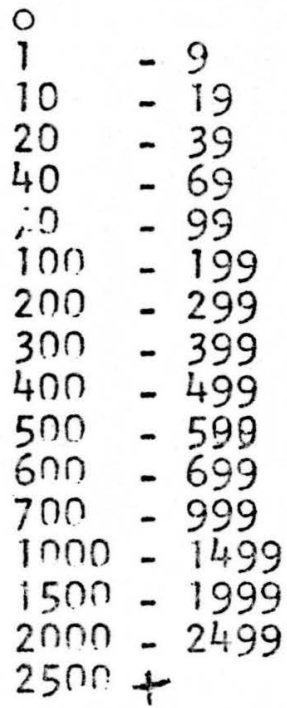

Before
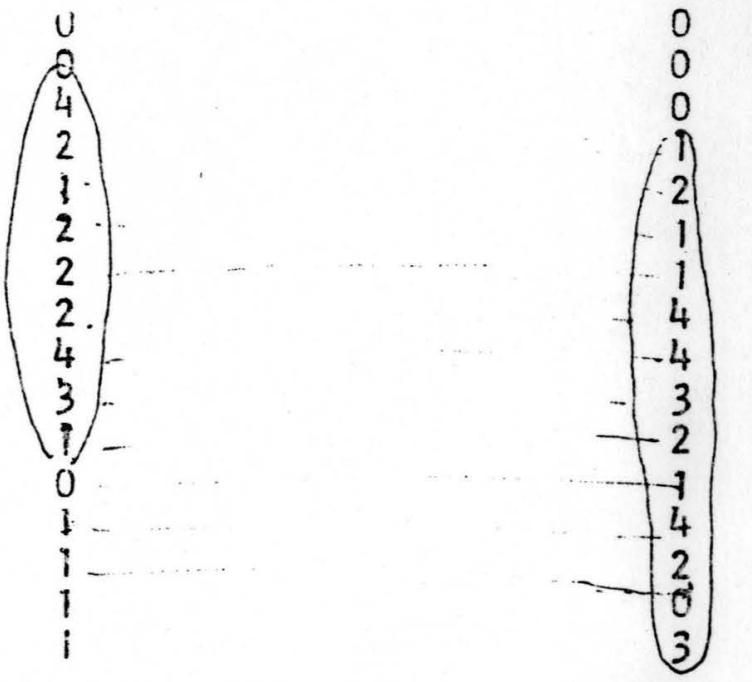
Before decisions regarding importation of pumps can be made, information about the ground water supply must be obtained.

Farmers need assistance (pub1ic of private?) in drilling wells (if the water supply is adequate for more wells.)

Care must be taken in selling pumps not to oppose 1 and reclamation and resettlement policies. The value of multiple ownership should be studied more carefully.

Although not shown clearly by this study, pumps used for supplemental irrigation from sources other than wells are quite possibly economical, especially if they can supply water on a more timely basis.

Parts and repair service is a critical need, as for traebors.

Competent agricultural and engineering advice should be sought regarding pump performance and irrigation water needs of various crops. 